Linköping Studies in Science and Technology

Dissertations No. 2065

\title{
Designing for Resilience
}

Navigating Change in Service Systems

\section{Vanessa Esperance Rodrigues}

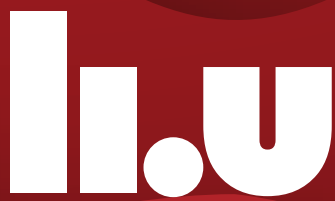

LINKÖPING

UNIVERSITY 
Linköping Studies in Science and Technology

Dissertation No. 2065

\title{
Designing for Resilience
}

\author{
Navigating Change in Service Systems
}

by

\section{Vanessa Esperance Rodrigues}

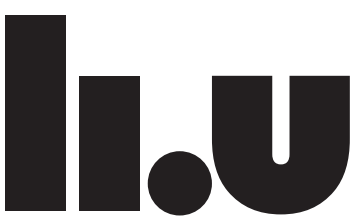

LINKÖPING UNIVERSITY

Department of Computer and Information Science

Linköping University

SE-581 83 Linköping, Sweden

Linköping 2020 
Copyright (C) 2020 Vanessa Esperance Rodrigues

ISBN 978-91-7929-867-8

ISSN 0345-7524

Printed by LiU-Tryck 2020

URL: http://urn.kb.se/resolve?urn=urn:nbn:se:liu:diva-165087

Published articles have been reprinted with permission from the respective copyright holder.

Cover design by Nikša Korper Žemva

Book cover graphic by Masher licensed through Shutterstock.com

Typeset in Helvetica and Garamond 


\section{Abstract}

Services are prone to change in the form of expected and unexpected variations and disruptions, more so given the increasing interconnectedness and complexity of service systems today. These changes require service systems to be resilient and designed to adapt, to ensure that services continue to work smoothly. This thesis problematises the prevailing view and assumptions underpinning the current understanding of resilience in services. Drawing on literature from service management, service design, systems thinking and social-ecological resilience theory, this work investigates how service design can foster resilience in service systems. Supported by empirical input from three research projects in healthcare, the findings show service design can contribute to the adaptability and transformability of service systems through its holistic, human-centred, participatory and experimental approaches. Through the analysis, this research identifies key intervention points for cultivating service systems resilience through service design, including the design of service interactions, processes, enabling structures and multi-level governance. The study makes two important contributions. First, it extends the understanding of service systems resilience as the collective capacity for intentional action in responding to ongoing change, coordinated across scales in order to create value. This is supported by offering alternative assumptions about resilience in service. Second, it positions service design as an enabler of service resilience by explicitly linking design practice(s) to processes that contribute to resilience. By extending the understanding of service systems resilience, this thesis lays the groundwork for future research at the intersection of service design, systemic change and resilience.

Keywords: service design, service systems, resilience, value creation, systemic design 


\section{Populärvetenskaplig sammanfattning}

För några veckor sedan bokade jag en resa till Nederländerna för att träffa min bi-handledare. När jag satt i soffan den kvällen med min bärbara dator, surfade jag på flygbolagens webbplatser, använde Skyscanner för att jämföra biljettpriser och letade efter tågförbindelser till Stockholm på min SJ-mobilapp innan jag bestämde mig för att mitt bästa alternativ var att flyga till Amsterdam från Linköping. I 30 minuter hade jag bläddrat igenom information från flera tjänsteleverantörer med hjälp av olika teknologier. Min upplevelse liknade troligen den som resenärer i många andra länder har av att boka en flygning år 2020. De som utformar dessa tjänster arbetar hårt för att se till att det är så. Om jag ser 20 år bakåt i tiden var det helt annorlunda. Då ringde jag min moster som arbetade på en resebyrå. Hon skickade sedan en offert med tre eller fyra olika resplaner och höll priset $\mathrm{i}$ tre dagar till en vecka så jag kunde bestämma mig. Tiderna har verkligen förändrats sedan dess! Istället för att min biljett ska faxas till mig och jag gör incheckning vid disken, kan jag nu bara checka in online och fortsätta med mitt mobila boardingkort.

\section{Vad betyder det här?}

Idag kan vi interagera med flera tjänster samtidigt. Även om resebyrån som en tjänst fortfarande existerar har tjänstelandskapet kring resor genomgått stora förändringar. Som kunder bryr vi oss mest om att komma till vår destination och ha en smidig resa med minimalt obehag. Det är tjänsteleverantörens ansvar att göra detta. Men saker går inte alltid så smidigt som väntat och i dessa fall är det servicepersonalen som måste improvisera för att uppfylla våra förväntningar. Ibland måste de ta itu med saker de inte har kontroll över. Ta till exempel det senaste koronavirusutbrottet. Medan flyg- och markpersonal inte kan göra något åt viruset $\mathrm{i}$ sig, måste de fortfarande vidta åtgärder för att säkerställa passagerarnas säkerhet. Detta kan kräva av- eller ombokning av flygningar, tilldelning av utsedda gater för passagerare som anländer från drabbade 
områden och screening av dem. På flygplatsen får passagerarna troligtvis uppdateringar om sina flygningar, information om hur och vart de behöver fortsätta, samt information om folkhälsosäkerhet. Detta kräver att flera organisationer inom och utanför flygplatsen samordnar och arbetar tillsammans för att säkerställa att vi som passagerare är väl omhändertagna. Vi vet inte heller hur uppkomsten av en sådan pandemi kan förändra hur vi reser i framtiden. I sådana fall räcker inte en snäv organisatorisk syn på hur man hanterar sådana händelser som ingår $i$ vardagliga arbetssituationer utan då krävs ett mer systematiskt angreppssätt som ser till systemet som helhet utan att förlora personer ur sikte i systemet.

\section{Vad bidrar min forskning till?}

Tjänstedesign har genom sin experimentella, iterativa, kreativa och användarcentrerade process, verktygen att hantera komplexa problem av den här typen. Med hjälp av resiliens-tänkande, förklarar mitt arbete distinktionen mellan anpassningsförmåga och förändringsförmåga som sätt att skilja mellan och navigera i pågående förändringar. Med stöd av forskning som utförs inom sjukvårdssektorn, positionerar mitt arbete tjänstedesign som ett sätt att möjliggöra resiliens i tjänster genom att växla mellan individuella, organisatoriska och systemnivåer.

\section{Nog med fackspråk, så vad betyder det egentligen?}

För att återvända till flygplatsexemplet skulle anpassningsbarhet stötta de åtgärder som görs för närvarande. Det skulle återspegla hur människor använder sin kunskap och sin erfarenhet för att hantera den uppkomna situationen. Till exempel hur de tilldelar gater/utgångar som förebyggande åtgärder och samordna flera flygbolags anställda vid utgångarna. Formbarhet, å andra sidan kräver övervägande av vad som ska göras på lång sikt och att hitta nya normaltillstånd. Skulle till exempel den pågående pandemin kunna leda till att desinficeringsförfaranden infördes innan ombordstigning och/eller avstigning? Vad krävs för att uppfylla dessa förändringar? Vem skulle behöva göra vad? Är det till och med rätt sak att 
göra? Men det är inte allt. Som tidigare påpekats genomgick tjänstelandskapet kring resande förändringar till följd av bland annat teknikutveckling och budgetföretagens uppkomst. Globaliseringen bidrog troligen till denna pandemi på fler sätt än vi kan föreställa oss. Sådana oförutsedda störningar kommer även inträffa i framtiden. Här saknas något. Till exempel, vilken roll skulle robotar spela i en sådan situation? Skulle de arbeta i stället för människor för att förhindra ytterligare kontaminering? Med hjälp av resilienstänkande vet vi lite mer om hur tjänstedesign skulle kunna erbjuda ett praktiskt sätt att hitta svar till dessa frågor. Detta kan uppnås genom att använda tjänstedesign som en arbetsätt för att identifiera och samordna nätverk av människor, organisationer och statliga institutioner för att uppnå ett gemensamt mål, och genom en sådan samordning identifiera vad som krävs för att hantera den aktuella situationen eller för att forma och övergå till det nya normaltillståndet. Med andra ord, hur man får tjänster att fortsätta fungera trots förändringar. 


\section{Acknowledgements}

I distinctly remember being asked at my $\mathrm{PhD}$ interview if I was certain I wanted to pursue a $\mathrm{PhD}$, since it can be a lonely endeavour. Without giving this any thought, I jumped at the chance and I can happily say this endeavour has been anything but lonely. Over the course of these five years, I have had the great fortune and pleasure of having some of the most wonderful people along with me on this journey.

I would like to start by wholeheartedly thanking my supervisor Prof. Stefan Holmlid for giving me this opportunity to research (which I thought was equal parts fascinating and frustrating) and urging me on. Stefan, I have learnt so much from you. Thank you for sharing your wealth of knowledge, experience, ideas and flights of imagination the way your mind works has and will continue to baffle and amaze me (in a good way (;). I appreciate you encouraging me to pursue different avenues, forge my own paths and trusting that I would find my way. Thank you for the fun summer readings and also to the rest of the Holmlids for inviting me to wonderful Swedish activities! I would not be doing a PhD if it wasn't for my co-supervisor Prof. Gaby Odekerken-Schröder. Thank you for recognising my potential and persuading me to do a PhD. You have been a wonderful, patient and thoughtful mentor. I knew I could always count on your support and feedback whenever I needed it. Your confidence in me has made all the difference.

Next, I would like to thank my extended supervisory team Dr. Johan Block and Prof. Dominik Mahr. Johan, thank you for listening to my half-baked ideas and ramblings, and all your valuable input and feedback along the way. Your ability to ask the right questions and encourage reflection has kept my research brain on its toes. I am also super grateful for the Swedish cultural education you have imparted to me (I think I am starting to blend in). Dominik, thank you so much for your support and helping me stay on track. Especially in these last few months, I appreciate you asking the critical questions and giving me the much-needed push in fruitful directions. It has been great to have you in my corner.

I am so fortunate to have been part of the SDIN family. I have benefitted from the collective brains and relationships in this EU project in more ways than I can imagine. I am deeply grateful for my fellow Early Stage Researchers - Maira, Filipe, Ana, Sebastian, Anna-Sophie, Josina, Martina, Nabila as well as Anja-Lisa, Andriy, Boris, Debarati and our guest ESRs Susan, Nina, Clara and Luisa. Jorge, thank you for writing all those emails urging us to complete our reports on time ;) But seriously obrigado for all the effort you have put in to getting us through the whole SDIN journey and just generally being yourself. I would also like to extend my gratitude and appreciation to 
the senior partners - Antonio, Bård, Birgit, Bosse, Daniela, Dominik, Gaby, Katerina, Lia, Pedro, Stefan and Tomas.

Next, I would like to thank the IxS family at LiU - Stefan, Mattias A., Johan B., Eva, Anna, Mathias, Tim, Ana, Fiona, Johanna, Johan $\AA$, Lisa and our guest researchers Eunji and Cara. I have enjoyed all our fikas, delicious baked goods and the lively conversations. Matti, thank you for always being so generous with your time and knowledge. I especially enjoyed your random walks into my office, bringing with you the most intriguing, hilarious, absurd, or oddly entertaining things, it never failed to amuse me. Mathias, you have been there for me since Day 1 when you tagged along on the bus because I wasn't sure how to get home, especially not after the combination of $\mathrm{PhD}$ pub, jetlag and long air-travel. It has been such a treat to meet a warm-hearted, generous, thoughtful person such as you (also literally, what with all your amazing cooking skills and stuffing me full with all the Swedish delicacies!). Tim, your positive attitude, kindness, support and endless supply of Dutch goodies have helped me power through many a rough day. Lisa, thank you for being my academic Yoda in those early days. Working with you has been an absolute pleasure and I hope we can do more of that in the future!

Over the years, the administrators have helped me through many an ordeal. I would specially like to thank Anne, for making sure I dotted all my i's and crossed all my t's, Lise-Lott, Inger and Karin for saving me so much time and headache with all the bureaucratic issues, Marie, Eva D., Eva E., Annette and Sandra. Thanks also to Nisse and Daniel for making sure I've been comfortable in my office. I would also like to thank everyone at IDA and especially those at HCS for being fantastic colleagues. Lunch conversations wouldn't have the same flavour without Karin, Marco, Arne, Jalal, Erik P., Jody, Erik B., Aseel, Anders, Magnus B., Nils, Annika and the IxS crew. Special thanks to the members of the LiU Design network for sharing all your design knowledge and experiences. I have also benefitted from being connected with several PhDs at IDA. Fredrik P., I have enjoyed our long chats and fika breaks. Amy, Mattias F., Camilla, Robert, Jonas, Antonia, Mina, Alachew, Rouhallah, Mattias T., Daniel, Sofia and Oscar, it was lovely getting to know you. I am most grateful to the Knights of the Round Fika Table - Ana, Robin, Tim, Evelina, Robin Keski, Sam, and more recently Riley, Emma and Jenny. I have missed you guys, our 3 o'clock fikas and the fruit train the most these past few months!

I also owe a big thank you to all participants across the projects. I am extremely grateful to have been hosted by various institutions and organisations over the years, without their enthusiasm and support this research would not have been what it is today. Tomas, thank you for inviting me to be a part of Experio Lab, working with you and the team has been inspiring. I would like to thank the national and local Experio Lab teams, especially Per, Olga, Louisa, Jonas, Camilla, Sofie amongst others, for being so 
welcoming, willing to share and just generally awesome! Hanna, thank you for opening up the world of person-centred care to me. Linda, it was great collaborating with you and I fondly remember my stays with your family. Katarina, thank you for letting me tag along, working with you has been rewarding and fun. I would also like to thank members of FoU i Sörmland and Region Sörmland for hosting me during my secondment. It has been a privilege to work with you all.

Thank you, Daniela S. and Anna, for hosting me at Politecnico di Milano. Filipe, I had the best time going out in Milan with you to all the fancy aperitivos! I am also grateful to my Design Girls - Daniela P. and Felicitas - grazie mille for the absolutely fun times at Head Office. Special shout out to Manuela, Andrea C., Patricia, Lele, Marianna, Ale, Matteo, Elena, Katarina, Marta, Virma and Giulia. Dank je wel colleagues at Maastricht University and tack så mycket to the folks at CTF for hosting me for shorter periods. Martina, my beloved WP partner, I am so happy I got to share this crazy journey with you. You made it so much more bearable with your enthusiasm and sunny disposition. I look forward to our continued collaboration. Susan, I have enjoyed our refreshing conversations over beer. Sebastian, thank you for being a caring friend and colleague, your genuine smile always lights me up. I also need to thank colleagues I have engaged with across different courses. You have brought fresh perspectives, challenged my assumptions and reshaped my thinking.

Along the way, I've also been extremely fortunate to have met people who have come to be trusted friends and close confidantes. So, thank you... Doanna for virtually taking me under your wing those first months in Linköping and making sure I didn't get lonely on the weekends. Biman, for helping me figure out things even before I landed in Linköping. Amelia, for our ritual lunch-dates, your pearls of wisdom and being a great sounding board, I am so grateful to have met you on Introduction day. Ranjith, for saving me from boredom several times. Gunnar, Ulla and Elsa, tack för att ni öppnade ert hem och era hjärtan för mig. Ni har varit som en familj, ett hem hemifrån. Ni har tagit så bra hand om mig. Jag kommer alltid att värdesätta våra stunder tillsammans. Den värme och generositet som ni har visat mig från första stund har förgyllt min tillvaro. Johan J., for the innumerable dinners, game nights and my first proper Swedish Midsummer celebration. Special thanks to my flat-mates over the years, Erica, Lisa, Simeon, Judit and Kevin, who significantly improved the quality of my home-life. I cherish all the great times we've had! I would also like to express my appreciation for my friends back home - Tresa, Gloria, Raquel, Purva, Elena, Swati, Lorain and Danica, the INKOM crew - Manon, Arienne, Carolin and Lulu, and SBE gang - Maike, Nethal, Raluca, Khalid, who have always listened to me patiently and kept me in the loop of all the happenings. Joao, for being my enduring fellow unicorn. I miss our tealightful dates. I would also like to thank the SNSG especially Cecilia, Matheus, Stefanie, Karol, Katarina, Desiree, Klara and Queli for all the good times. 
Josina, I could not have asked for a better VIP friend, sloth-buddy to share this rollercoaster ride! I have deeply enjoyed our travel, food and writing adventures. Collaborating with you has been extremely enriching. You always push me to think further, try harder, be better and never give up. Your valuable input and critical feedback in the last months have made this work all the better. You have been an inspiration, one of the most amazing people I have had the privilege of working with, and I hope we can continue our adventures together!

Ana, you and Nikša moving to Linköping is perhaps the best thing that could have happened to me (except maybe Andy moving here). You have been a rock, helping me weather the storm this past year. Thank you for the productive working sessions, timely feedback, constant support, for helping me stay on track and being my not-so-secret Sveti Nikola. You bring 'meaning' to my life ;) Big thank you to Nikša for this lovely cover design! I have loved all of our weekend food and drink binges. Thank you both for being so warm-hearted, generous, loving and all-round awesome humans. You make such great friends and neighbours. I cannot wait to share the exciting times ahead with you and your little princess!

I would like to extend my appreciation to members of the Rodrigues, Noronha and Dassel families. I am deeply grateful to Uncle Savio and Aunty Veronica for always encouraging and supporting my academic endeavours. I would also like to thank my husband, Andrea. Andy, there are not enough words to describe how grateful I am to have you in my life. You've made sure I've been well-fed, and put up with my all my early mornings, late nights, constant thesis talk and mood swings. I truly appreciate all the sacrifices you have made to see me through this $\mathrm{PhD}$ process. Thank you doesn't even begin to cover it. This whole journey has probably been the toughest on you but you have kept me grounded through it all. Ich liebe dich!

And last but not the least, I am especially thankful for my parents Santana and Maria, my eternal cheerleaders, for their faith in my abilities and relentless support across the miles. Mama and Dada, thank you for raising me to be a fiercely independent and confident person. Without your unconditional love, support and encouragement, I would never reach the heights I set out to achieve. This thesis is dedicated to you.

Vanessa Rodrigues,

Linköping, April 2020 


\section{Table of Contents}

ABSTRACT ..............................................................................................................II

POPULÄRVETENSKAPLIG SAMMANFATTNING........................................ V

ACKNOWLEDGEMENTS............................................................................ IX

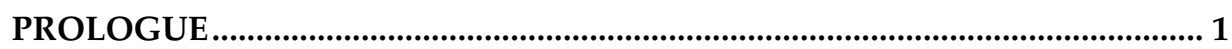

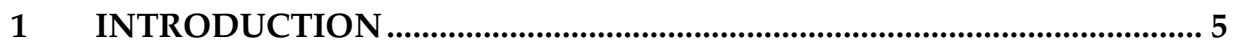

1.1 AIM \& RESEARCH QUESTIONS ............................................................... 9

1.2 SCOPE

1.3 OVERVIEW OF APPENDED PAPERS.............................................................12

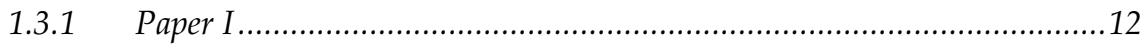

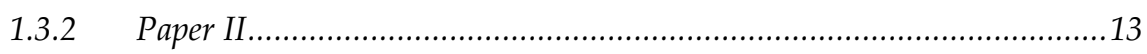

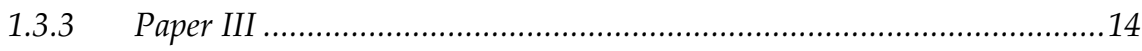

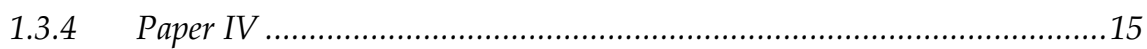

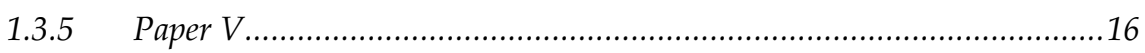

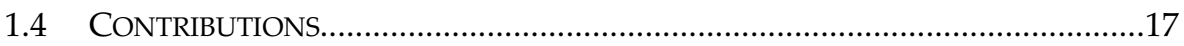

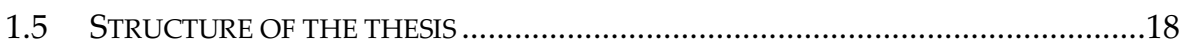

2 THEORETICAL FRAME OF REFERENCE .....................................................19

2.1 THE ADVANCEMENT OF SERVICE RESEARCH................................................19

2.1.1 Towards a Service Logic..................................................................19

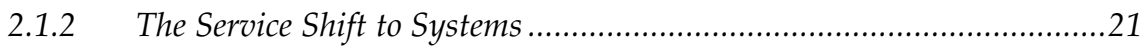

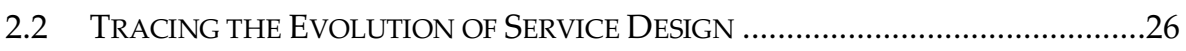

2.2.1 Service Design in New Service Development (NSD) ............................26

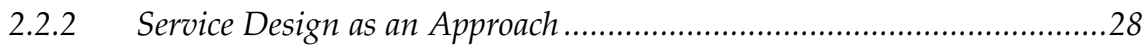




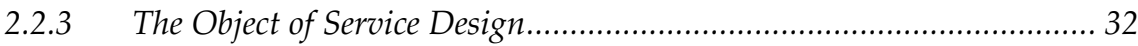

2.2.4 The Practice(s) of Service Design ................................................. 34

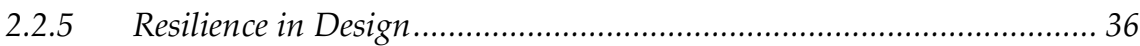

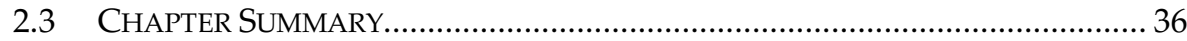

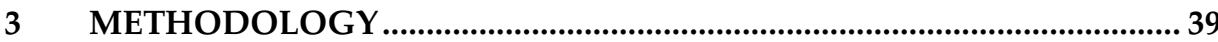

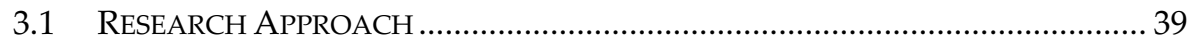

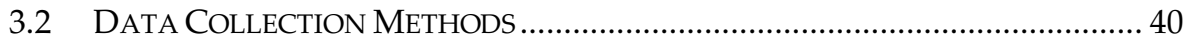

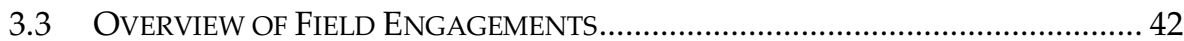

3.3.1 Chronically Engaged 2.0 (SE: Kroniskt Engagerad 2.0) ...................... 43

3.3.2 Safe E Effective Discharge (SE: Trygg och Effektiv Utskrivning) ......... 48

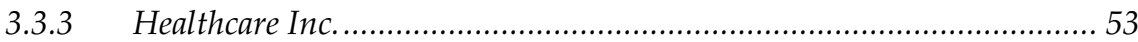

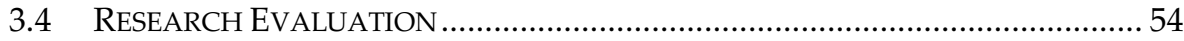

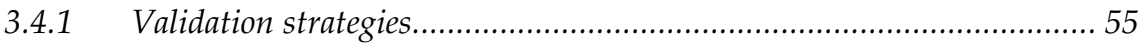

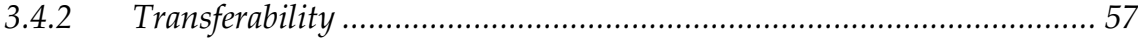

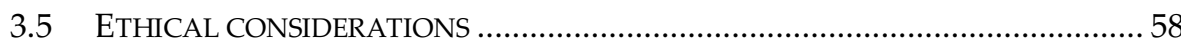

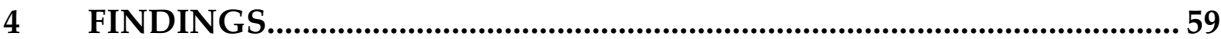

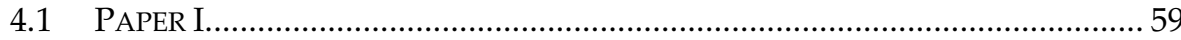

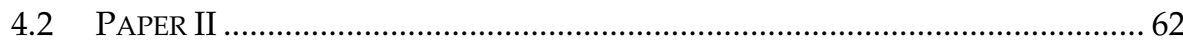

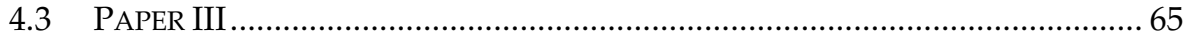

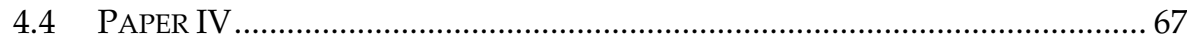

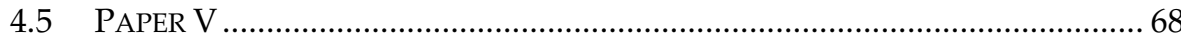

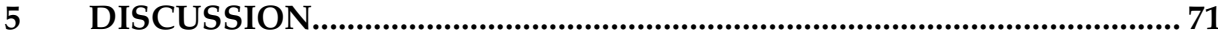

5.1 EXTENDING THE UNDERSTANDING OF RESILIENCE IN SERVICE ...................... 71 
5.2.1 From Individual to Collective..........................................................74

5.2.2 From Intrinsic Property to Intentional Capability ..............................76

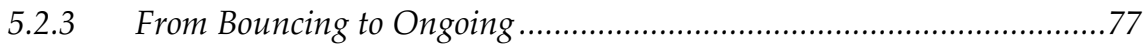

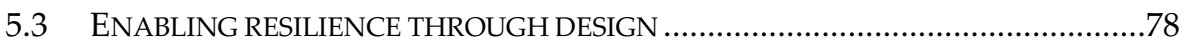

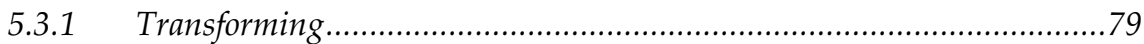

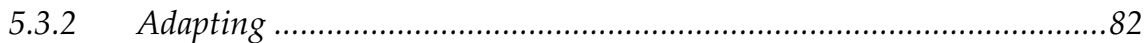

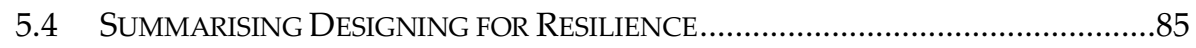

5.4.1 Implications for Design Practice .....................................................89

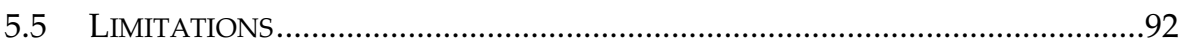

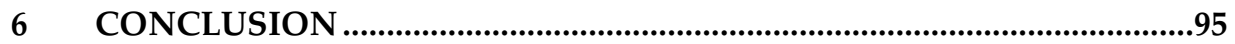

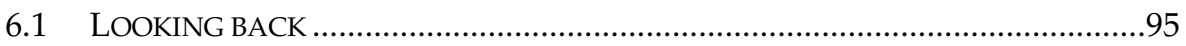

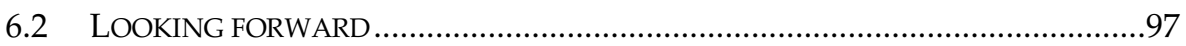

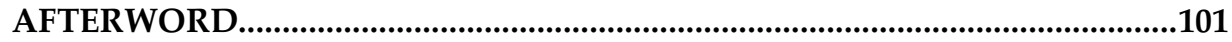

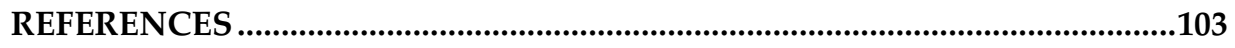

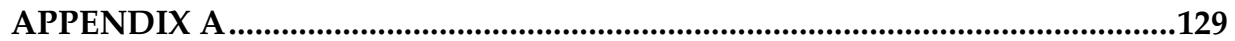

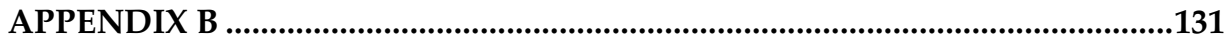

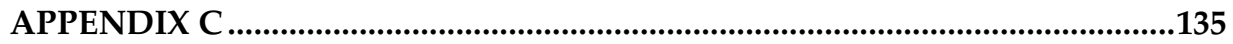




\section{Prologue}

"Nothing will unfold for us unless we move toward what

looks to us like nothing: faith is a cascade."

- Alice Fulton

Every research journey is an exploratory quest for knowledge. According to the Wikipedia entry', "In literature, the object of a quest requires great exertion on the part of the hero, who must overcome many obstacles, typically including much travel." My quest is no different. I am not trained as a designer in any discipline. I do however come from a strong service background armed with a Bachelor's degree in Hospitality and Hotel Administration (which we jokingly referred to as B.Sc. HaHA). Over the course of those three years, I learnt and gained practical knowledge in several subjects spanning food and beverage service, food production, housekeeping, guest relationship management, engineering, hotel law, strategic management and finance that would help me grasp the intricate workings of hotels and hospitality. A culture of service and servitude is embedded throughout the programme, with the famous Indian phrase

\footnotetext{
${ }^{1}$ Extracted from https://en.wikipedia.org/wiki/Quest on 7 November 2019.
} 
"Atithi Devo Bhava", (Hindi: अतिथिदेवो भव; English: "The guest ${ }^{2}$ is equivalent to God") burned into our pliant minds from introductory day. The design aspect is less pronounced but not absent. My brush with design and aesthetics came from learning to artistically plate food, to garnish and serve a cocktail with flair, to lay a festive table, to furnish a room to create a certain atmosphere, letting the feel of fabric, the use of textures and lighting evoke a particular mood, and most importantly shaping the service experience I wanted guests to have. However, none of this struck me as design then. Fresh out of college I was hired as a management trainee at an Indian five-star hotel chain in the Food \& Beverage service. For two and a half years, as Management Trainee and then Assistant Banquet Manager I ate (a lot), slept (barely), lived, breathed hospitality and service, moving tables, chairs, events and mountains (not literally) for guests. All of our planning and introduction of new service complements (e.g. mini-golf and other games during lunch breaks for corporate guests' training sessions) came from understanding the underlying needs of our guests, sometimes from our post-event feedback card but more often an aha moment garnered in informal conversation or observation of the actions on the banquet floor. We tried out new service complements with smaller parties, asked hosts and guests for their feedback before deciding to continue with, improve or discard the idea. We often enacted everyday situations with guests to train our staff how to respond, particularly if it was unexpected or disruptive. We sat late into the evenings sketching floorplans and buffet service layouts, randomly grabbed whatever was at hand in the banquet area to simulate the set-up, figuring out how we separate the foyer when multiple events were taking place so every guest had a smooth experience while navigating the banquet area. None of this struck me as design either.

\footnotetext{
${ }^{2}$ To this day I cannot let go of the hotel vocabulary and find it difficult to refer to guests as users, client or customers.
} 
Fast forward to me doing my Masters in Strategic Marketing at Maastricht University in 2012. I had decided to broaden my horizons and moving to a new country, learning something different fit the bill. I was amazed at how Predictably Irrational (Ariely, 2010) we were and how this irrationality drove us to make choices we didn't necessarily choose for ourselves. I enjoyed my studies and the new outlook it afforded me but something didn't sit right with me. Marketing allowed my creativity and imagination to run wild, but after having been so focused on realising guests' visions of their banquet experience, I struggled with the feeling that my current work imposed fictive aspirations rather than drawing on real ones. I missed the sense of collective accomplishment at the end of each day, knowing that we had achieved for our guests what they wanted. I learnt about New Service Development (Scheuing \& Johnson, 1989) where design was introduced as one of the stages in the development process; service designers were unheard of (Gummesson, 1989). One of the last classes I took was on Service Innovation and that was where I came across Design Thinking - "a methodology that imbues the full spectrum of innovation activities with a human-centered design ethos. By this I mean that innovation is powered by a thorough understanding, through direct observation, of what people want and need in their lives and what they like or dislike about the way particular products are made, packaged, marketed, sold, and supported." (Brown, 2008 , p. 1). I never thought of my hospitality job as particularly innovative but that sentence resonated with me because it captured the essence of my work. The article went on to describe cases using words like brainstorming, ideation, prototyping, refinement, people-first, holistic, exposing me to a rudimentary vocabulary I never knew about or thought I needed. But it roused my curiosity, I wanted to learn more. After graduating, I applied and was accepted as a project management assistant at the Service Science Factory (SSF), where I was first exposed to using design methods. Simultaneously, I signed up for an online course 'Design Thinking for Business Innovation' given by Darden Executive Education on Coursera. It was a good start. When I returned home that autumn, I got my hands on copies of 'This is service design thinking: Basics, tools, cases' (Stickdorn, 
Schneider, Andrews \& Lawrence, 2011) and 'Change by Design' (Brown, 2009). Reading opened up my mind but it also stirred in me the need to do. Opportunity came knocking when Gaby, wrote to me informing of the Service Design for Innovation (SDIN) network and encouraged me to apply. I did not make the cut for the position I initially applied to. I was dejected but a week later I was invited by Stefan to apply for another position at Linköping University. I read the description - service prototyping it said, highlighting roleplay, bodystorming, service walkthroughs. I knew what those words meant now, the promise they held, and thought - 'I can do this'. The interview was done, weeks passed and I waited with bated breath. I started to lose hope, after all I didn't have a design background. Until four weeks later it happened - acceptance to the position. The door had opened and I walked through. 


\section{Introduction}

"There is nothing in a caterpillar that tells you it's going to be a butterfly."

- R. Buckminster Fuller

Disruptions in the form of innovations, economic crises or ecological disasters can render the world temporarily unpredictable, leaving service system actors struggling to survive, slowly adapt or forced to transform. This is more than apparent in the current times we live in. The ongoing pandemic is testament to the fact that unexpected shocks can turn the world topsy-turvy. The enforced lockdowns have forced us to rethink our ways of working, how we conduct our businesses and try to support employees despite all the challenges. Ideas such as basic income, perhaps thought of as untenable, now seem like a plausible reality (Mulgan, 2020).

When faced with such crises, resilience surfaces as a necessary condition for recovering from or adapting to adversity and shocks (Maglio, Kwan \& Spohrer, 2015; Manzini, 2015). Connected with the pandemic, some scholars have also started 'Resilience Journaling', "to focus on the implications of the current crisis on emerging new practices, and behaviours and values that drive learning, innovation and work to potentially build a new future" (Snowden \& Begovic, 2020). 


\section{Chapter 1}

The concept of resilience has found application in a variety of fields, such as engineering, human resource management (Lengnick-Hall, Beck, \& Lengnick-Hall, 2011), child welfare (Skovdal \& Andreouli, 2011), supply chain management (Christopher \& Peck, 2004), disaster management (Bruneau et al., 2003) as well as individual (Luthar, Cicchetti \& Becker, 2000) and organisational psychology (Barnett \& Pratt, 2000). Although resilience has been discussed across several disciplines, its definition and the ways to achieve it remain ambiguous (Taysom \& Crilly, 2017). Elevated to buzzword status in recent years, it seems that everything can and should be resilient (Boin, Comfort, \& Demchak, 2010). Even the European Commission's (2014, p. 10) call for improving resilience in health systems, highlights the need to "adapt effectively to changing environments and identify and apply innovative solutions to tackle significant challenges shortages of expertise/resources in specific areas, unexpected surges in demand (e.g. owing to epidemics), etc. — with limited resources". This statement indicates that resilience can play a role in understanding the broader concept of adaptability.

In today's interconnected world, services are cocreated by multiple actors in networked constellations, indicating increased complexity of the service context (Sangiorgi, Patrício, \& Fisk, 2017). Traditionally limited to dyadic interactions, research on services has now evolved to incorporate many-tomany interactions (Gummesson \& Mele, 2010) amongst actors in service systems (Maglio \& Spohrer, 2008; Maglio, Srinivasan, Kreulen, \& Spohrer, 2006; Spohrer, Maglio, Bailey, \& Gruhl, 2007). Service providers are shifting from a dyadic perspective towards defining their role and contributions within service systems (Blomberg \& Darrah, 2015; Sangiorgi et al., 2017). Such service systems are configurations of people, information, technologies, and other resources that interact with other service systems to cocreate value (Maglio, Vargo, Caswell, \& Spohrer, 2009). As services play an increasingly prominent role in society, service researchers draw attention to the resiliency of service systems as one aspect of continuous improvement required in service systems to sustain our very way of life (Larson, 2016). 
During the COVID-19 crisis, service organisations and systems, particularly healthcare, have been severely impacted by acute shortages of medical personnel and equipment. It has left hospitals and medical clinics struggling to meet demands for care. Other services, such as aviation and retail, have nearly ground to a standstill, and restaurants are resorting to 'delivery only' to satisfy their patrons' needs. In other words, service providers world over are trying to cope with the current situation in ad hoc ways. This underscores the need for developing flexible, adaptive service systems (Ostrom et al., 2015). This need is also echoed in the calls for the design of resilient service systems (Maglio et al., 2015; Manzini, 2015). Service scholars have also reinforced the need for understanding how adaptability might affect the resilience of service systems (Barile, Lusch, Reynoso, Saviano, \& Spohrer, 2016). Some resilience scholars surmise that "the resilience of 'natural' systems, though complex, pales in comparison with evaluation of human systems, largely because humans have foresight and creativity and can adapt in advance to anticipated future states" (Pendall, Foster, and Cowell, 2007 qtd. as cited by De Bruijne, Boin, and Van Eeten, 2010, p. 31). However, the concept of resilience is not without its issues. Others argue that resilience is being used an umbrella term to denote system characteristics and "its definition has become so broad as to render it almost meaningless" (Klein, Nicholls, \& Thomalla, 2003, p. 42). This problem also plagues service research, with the term being used in a rather eclectic way in relation to individuals (Azab, Clark, \& Jarvis, 2018), communities (Cheung, McColl-Kennedy \& Coote, 2017), organisations (Cheung et al., 2017), systems (Lusch, Sagarin, \& Tang, 2016), economies (Borchert \& Mattoo, 2010) and industry sectors (Baron, Harris, Elliott \& Smith, 2005). Despite this fragmented understanding, there is consensus that resilience can be a powerful driver for change in the face of shocks and disruptions.

Within service discourse, researchers recognise service design's potential for innovating complex service systems and value networks (Ostrom et al., 2015). Service design here is understood as a human-centred, creative and iterative methodology for the development of new services Blomkvist, 


\section{Chapter 1}

Holmlid \& Segelström, 2010). I argue that service research scholars could also harness the potential of service design to enable resilience in services. Currently, designers (amongst others) are rallying to tackle issues from designing equipment (AgenteCOM, 2020) to experimenting with policy to address the fallout from the pandemic (Annala, Quaggiotto \& Wong, 2020). Designing for resilient service systems requires not only a better understanding of resilience, but also of how practitioners can contribute to developing such resilience. Through its inclusive, experimental, participatory, transformative and holistic approach (Karpen, Gemser, \& Calabretta, 2017; Stickdorn et al., 2011), service design can provide new, shared and 'orienting' visions for the future (Sangiorgi, 2010). A new, emerging paradigm reframes design's role from mere problem solving to transforming systems, taking the complex nature of the problem situation as its starting point (Dorst, 2019). Based on existing research, service design seems like a promising approach for building much needed resilience in service systems.

A resilience approach to management assumes the unexpectedness of future events and requires a qualitative capacity to accommodate such events (Holling, 1973). This aligns well with the design for service perspective, which acknowledges the potential for creating the right preconditions for service interactions to occur (Meroni \& Sangiorgi, 2011; Wetter-Edman et al., 2014). Other similarities between design and resilience include the blurring distinction between outcome and activity, and the ambivalent status of boundaries and interfaces (Cowley, Barnett, Katzschner, Tkacz, \& De Boeck, 2018). Despite these complementary aspects, the understanding and application of resilience in design practice can be difficult (Baek, Meroni \& Manzini, 2015). Therefore, a framework that approaches resilience at the systemic level, and clarifies the interplay between different aspects of service systems change across scales, is needed for (design) practitioners to be able to address resilience through service design interventions. In other words, a more practical understanding of 
how to enable resilience is required as it would influence the adaptability of systems.

\subsection{Aim \& Research questions}

Against this backdrop, the aim of this thesis is to explore the concept of resilience in service systems in order to provide a richer understanding and better account for how service design can enable resilience in service systems.

In pursuit of this aim, two research questions are formulated to guide the inquiry in this thesis:

RQ 1: How should resilience in service systems be understood?

While resilience originates from an ecological perspective (Holling, 1973), it has been extensively studied in various contexts and disciplines. Its understanding in service research is mainly focused on resilience at the individual level. However, services are not limited to interactions and require consideration of the process and system (Edvardsson \& Olsson, 1996) that support its realisation. Similarly, organisational resilience is a function of both individual and organisational responses (Bhamra, Dani, \& Burnard, 2011). Since these levels are linked, addressing how to support resilience should recognise their inter-connectedness and the influence of relationships in responding to disruptive situations. Given the current shift to a more systemic understanding of service (Sergio, Robert, Javier, Marialuisa, \& James, 2016; Spohrer, Vargo, Caswell, \& Maglio, 2008; Vargo \& Akaka, 2012), an accompanying understanding at the systemic level is required. I problematise the existing literature on resilience within service research and address the assumptions hampering a better understanding of resilience from a service systems perspective. However, this work strives to create an understanding of service system resilience rather than define a truth about it (Alvesson \& Sandberg, 2011). 


\section{Chapter 1}

RQ 2: How might Service Design enable resilience in service systems?

In addition to understanding resilience in service systems, designing resilient service systems demands more practical knowledge of the process of intentionally building resilience in such systems. Service design is a promising approach to support adaptation to systems change. Over the last two decades, Service design as a design practice and research area has strengthened its position as a design-led approach to service innovation (Kimbell \& Blomberg, 2017; Meroni \& Sangiorgi, 2011). Research has shown that design, together with management and engineering approaches, can contribute to envisioning and designing complex service systems (Blomberg \& Darrah, 2015; Legeby, McAleenan, Andersson, \& Holmlid, 2018; Patrício, Fisk, Falcão e Cunha, \& Constantine, 2011). The Design for Service perspective acknowledges that design has the ability to only create the right preconditions that facilitate certain forms of interactions and relations, but not to accurately plan and regulate the service (Kimbell, 2011; Wetter-Edman et al., 2014). This exploratory work adopts this more inclusive view, and through the study of three field engagements in the healthcare context, investigates how a human-centred, participatory and experimental approach can foster resilience in service. Taking an abductive and reflexive approach (Alvesson \& Sköldberg, 2009), this thesis iteratively moves between theory and practice to answer the research questions (Figure 1.1). 
Introduction

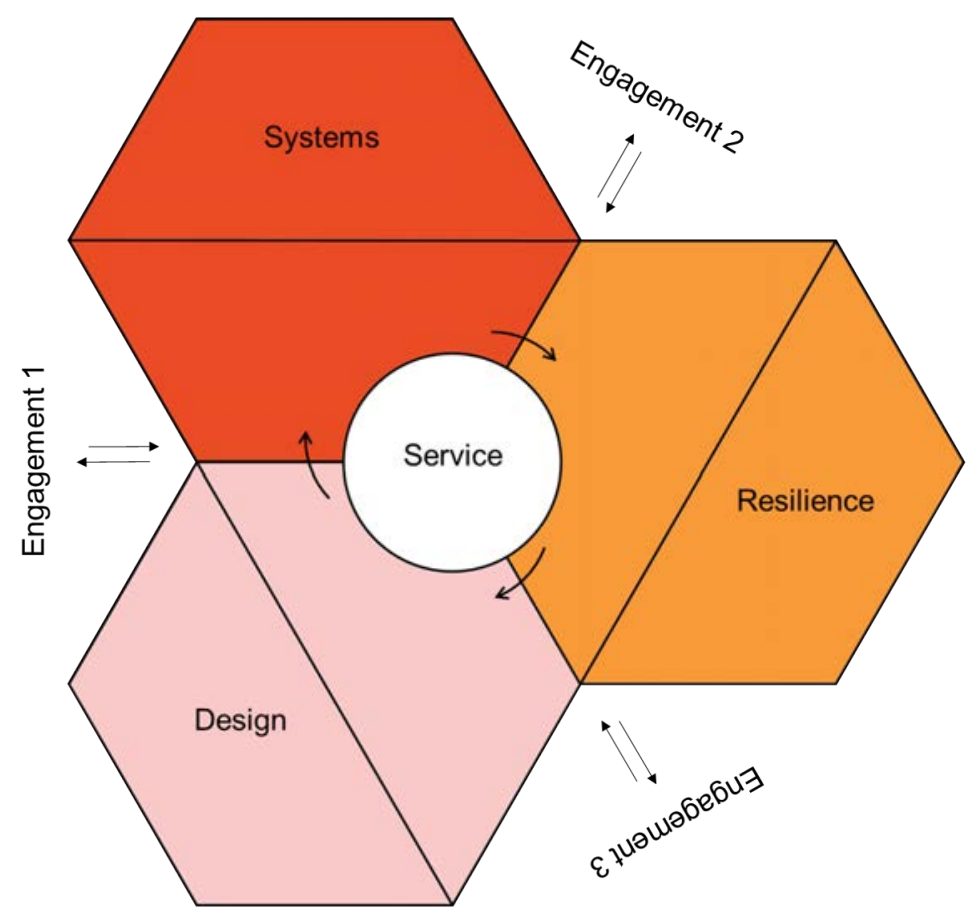

Figure 1.1: Dialogic approach between theoretical and empirical inputs. Author's own illustration.

\subsection{Scope}

The main audience of this thesis is service research scholars, firstly those working with service design and secondly those working with service. This work might also be of general interest to other resilience scholars, design research scholars, design practitioners and those interested in the practice of service design. This thesis is positioned in service research, building on both design and service disciplines to inform its understanding of service design. It develops a multi-scalar understanding of resilience drawing on literature from service research, systems thinking, resilience theory and service design. While co-design and participatory design have influenced service design, these are not discussed in depth in this work. The theorising of resilience serves as the conceptual glue that fuses the studies carried out in individual field engagements. This thesis does not examine the role of the designer in supporting service development (Wetter-Edman, 2014; Yu 
\& Sangiorgi, 2018a) or service design as an approach to innovation (Korper, Holmlid \& Patricio, 2018; Lassila, Rieple \& Ennis, 2017). Instead, this thesis uses a theoretical resilience lens to gain a nuanced understanding of how service design can be applied to foster resilience. In doing so, it also touches upon adoption of service design approaches and describes specific interventions that help cultivate resilience in services. However, this framework is still in its nascent stages. Identifying and constructing assessment measures for resilience in services is beyond the scope of this thesis.

\subsection{Overview of appended papers}

This section briefly summarises each of the paper included in the thesis. For an overview of the distribution of work please see Appendix A.

\subsubsection{Paper I}

Malmberg, L., Rodrigues, V., Lännerström, L., Wetter-Edman, K., Vink, J., \& Holmlid, S. (2019). Service Design as a Transformational Driver Toward Person-Centered Care in Healthcare. In M. A. Pfannstiel \& C. Rasche (Eds.), Service Design and Service Thinking in Healthcare and Hospital Management: Theory, Concepts, Practice (pp. 1-18). Cham: Springer International Publishing.

In this book chapter, we forward service design as a key driver to aid in catalysing the transformation of health service systems toward personcentred models of care. We integrate literature on service design and person-centred care (PCC) to better understand how a service design approach can aid in the transition toward PCC. Synthesised from existing literature, this chapter offers a framework for transitioning from the biomedical model toward PCC, highlighting key changes across four dimensions: contexts, roles, processes, and outcomes. We then show the alignment between PCC and SD across these dimensions and elucidate how SD can help to catalyse related changes with the support of specific methods. In doing so, this chapter offers a guide for healthcare practitioners 
looking to use SD to support the transformation toward PCC and builds a platform for future research at the intersection of SD and PCC. This thesis links these dimensions as places to intervene when designing for resilience in service systems.

\section{Background and author contributions}

This chapter was the initiative of the first and fourth author. I have contributed with the development of the framework transitioning from the biomedical model to PCC, the discussion of the alignment and the knowledge of methods that can support the transition across the identified dimension. This work draws on all of the authors collective experiences within the context of Experio Lab and the Swedish healthcare system in general. The preparation of the manuscript was led by the first author with support from all other authors.

\subsubsection{Paper II}

\section{Rodrigues, V., Holmlid, S. Mahr, D., \& Odekerken-Schröder, G., Leveraging service design to enable resilience in services. (To be submitted).}

This paper builds on the ideas presented at the QUIS 16 conference. It is an empirical paper that defines service resilience in an effort to move toward a common understanding of the term in the service context. The theoretical perspective underpinning this paper is an analytical framework from resilience thinking on social-ecological transformations. It uses this framework to examine the field engagement Safe and Efficient Discharge (SED) as an empirical case, to explore how service design can contribute to transformation in service systems. Here we define service system resilience as the collective capacity for intentional action in responding to ongoing change, coordinated across scales in order to create value. It identifies three meta-stages - familiarising, experimenting and anchoring that occur during design processes with transformational aims. It identifies nineteen specific design 
Chapter 1

practices that occurred during this process and explicitly links them to factors that contribute to enabling resilience.

\section{Background and author contributions}

This paper is developed for submission to a service journal. My co-authors have contributed with critical feedback. One of the co-authors has been partially involved in data collection. I have done the writing and analysis iteratively and with appropriate feedback.

\subsubsection{Paper III}

Rodrigues, V., Blomkvist, J., \& Holmlid, S. (forthcoming). Patterns of disruption: diagnosing response mechanisms in actor networks. Accepted to ServDes 2020.

Paper III deals with the response of healthcare personnel to disruptions in service. This paper focuses on the network aspects of employee response. This qualitative study utilises a modified Critical Incident Technique (CIT) method with a generative design activity (Sanders, 2000) to explore how actors respond in disruptive situations. First, it presents an in-depth qualitative investigation of deviating service situations, identifying eight patterns of service disruptions. Second, it develops a disruption ripple model that allows a conceptual exploration of the focal service-providing actor's network activation in disruptive situations. Third, it identifies five tensions affecting network actors' response to disruptions. Fourth and finally, it methodologically contributes with a modified Critical Incident Technique augmented with a generative actor mapping activity. 


\section{Background and author contributions}

The paper is the outcome of my second secondment at Politecnico di Milano in collaboration with Healthcare Inc ${ }^{3}$. I led the preparation of the interview protocol and took part in all 10 interviews conducted. 6 of these interviews were conducted with a translator in Italian and I conducted the other 4 interviews in English. The Italian interviews were transcribed and translated by a translator. I carried out the data collection, compilation and analysis, with support from co-authors to interpret and understand the findings.

\subsubsection{Paper IV}

\section{Rodrigues, V., \& Holmlid, S. (2017). Discovering Service Variations through Service Prototyping. The Design Journal, 20 (sup1), S2247- S2257.}

Paper I investigates how the use of a service prototyping technique enables participants to explore the variations inherent in services. The challenge of dealing with variations is an everyday reality for most services, particularly those such as healthcare. The heterogeneous nature of services has been attributed to difficulty in standardization related to outcomes, production performance, time and predominantly the participation of customers (Moeller, 2010).

In terms of variation, prototyping the service facilitated partial expression of at least four out of the five types of variability (Frei, 2006) introduced by customers, in this case patients. From the value creation perspective, this study maps the articulated variations to the specific spheres within the service logic framework (Grönroos, 2008; Grönroos \& Voima, 2013). This paper clarifies how prototyping a service allows people untrained in design

${ }^{3}$ Fictitious name used to preserve anonymity. 
to diagnose variations that may occur in a future service and the decisionmaking process in accommodating variation. Further, the knowledge gained enables improved value co-creation opportunities in a service.

\section{Background and author contributions}

This study was based on the ideation and service prototyping workshop carried out as part of the Chronically Engaged 2.0 (CE2) project. The project's aim of developing healthcare services for individuals diagnosed with chronic illnesses guided the development of the prototypes. The project was commissioned by Region Sörmland and my position was funded as part of my first secondment at Experio Lab.

I did not take part in the seminars/workshops preceding the service prototyping. I, along with two senior researchers, was partially responsible for preparation and design of the service prototyping exercises, but participated only as an observer during the actual exercise. The data was compiled and primarily analysed by me, supported by input from other observers. The final manuscript was prepared by me with the support of my co-author.

\subsubsection{Paper $V$}

Rodrigues, V., Blomkvist, J., \& Holmlid, S. (2018). Perceived Action Potential: A strong concept in development. In ServDes2018. Service Design Proof of Concept, Proceedings of the ServDes. 2018 Conference, 18-20 June, Milano, Italy (Vol. 150, pp. 1162-1174). Linköping University Electronic Press.

Paper IV draws on strong concepts from interaction design as a generative intermediate-level form of knowledge, to conceptualise perceived action potential (PAP) as a strong concept through the use of illustrative examples. PAP refers to the subjective interpretation of an individual's (own) scope of action in new or unforeseen situations. As active participants of a service, users bring their resources, competences and capacities into these interactions. How actors engage in a service is largely influenced by relation- 
ships and their willingness and ability for resource integration. Thus, trying to comprehend the subtleties of what drives actors' resource integration activities could be valuable when designing for service. It highlights improvisation, mandate and resources that enable improvisation as design elements.

\section{Background and author contributions}

This paper builds on the result from Paper IV to conceptualise PAP. The paper utilised empirical illustrations from the reflection films developed in the Kroniskt Engagerad 2.0 project, a co-author's work with a large telecom service provider and a real-life example from my own experience. While I led the writing, analysis and preparation of the document, all tasks were supported by the co-authors.

\subsection{Contributions}

This thesis offers three main contributions in response to the research questions. First, it defines service system resilience as the collective capacity for intentional action in responding to ongoing change, coordinated across scales in order to create value, supported by alternative assumptions underpinning the understanding of resilience. Second, building on two approaches to change (i.e., adaptability and transformability) and insights from the empirical material, it articulates the strategic focus and corresponding response actions in order to enable resilience when dealing with different types of change. By specifying these two approaches to change, it enables service design practitioners to adjust the aims of their practice depending on the nature of change. Third, it provides a practical framework detailing where and how service design can intervene in a system to influence factors that enable resilience. By identifying the multi-scalar oscillating nature of resilience in service systems, it highlights the shifting object of service design when designing for resilience. 


\subsection{Structure of the thesis}

This is a compilation thesis and as such, it contains two parts: a kappa, which covers and summarises the work in the individual papers, and a section consisting of the appended research papers. Following this introduction (Chapter 1), this work in this research has been structured into five chapters:

- Chapter 2 - Theoretical Frame of Reference: description of the theoretical domain of service systems and service design in service literature.

- Chapter 3-Methodology: a summary of the methodological approach, empirical field engagements of this study, the methods employed in each context, evaluation criteria for the research, and ethical considerations.

- Chapter 4 - Findings: a description of the findings from the individual papers.

- Chapter 5 -Discussion: a discussion of the findings in relation to the research questions - defining service system resilience, outlining alternative assumptions, summarising designing for resilience and the limitations of this research.

- Chapter 6 - Conclusion: a summary of the contributions and opportunities for future research. 


\title{
2 Theoretical Frame of Reference
}

\author{
"Reading furnishes the mind only with materials of knowledge; it \\ is thinking that makes what we read ours."
}

- John Locke

This chapter presents an overview of the theoretical frames of reference used in this thesis. I have employed a problematisation approach (Alvesson $\&$ Sandberg, 2011) to identify and understand the underlying assumptions in the literature. While the thesis draws on multiple streams of literature to relate this work, it positions itself in relation to service research.

\subsection{The advancement of service research}

Research on services is primarily associated with marketing and operations in the business management stream of literature. The first sub-section traces the emergence of service research and its changing logic over the years. The second sub-section describes the shift to a systems perspective and problematises issues in current service system literature in relation to understanding resilience in service systems.

\subsubsection{Towards a Service Logic}

In an effort to lay the groundwork for service research, scholars sought to define services and how to market them, frequently describing them in opposition to goods. This period between 1950 to 1980 has been referred to as Crawling out (Briscoe, Keränen, \& Parry, 2012). Shostack (1977) criticized the traditional marketing mix for being ill-equipped to deal with 


\section{Chapter 2}

the intangibility inherent to services. Several years later, Zeithaml, Parasuraman and Berry (1985) proposed four unique service features based on how services were treated in extant literature - Intangibility, Heterogeneity, Inseparability, and Perishability (IHIP). Intangibility refers to the invisibility of service elements, Heterogeneity concerns variability in service performance and outcomes, Inseparability refers to simultaneous production and consumption, and Perishability refers to the incapability to store services. Amongst these, Intangibility was considered the most critical, as it from this characteristic that all others depart (Zeithaml et al., 1985). While the IHIP model was accepted and favoured at the time, it has recently come under criticism. The main critique is related to the understanding of services based on what they are not, described in relation to characteristics ascribed to products, thereby obscuring possibilities of identifying important aspects of services (Wetter-Edman, 2011). Lovelock and Gummesson (2004) demonstrated the ambiguous interpretation of these features that were inapplicable to all types of services. New conceptualisations of the nature of services emerged emphasising service viewed as a category of market offerings or as a perspective on value creation (Edvardsson, Gustafsson, \& Roos, 2005). Others include the property of non-ownership and access to resources (Lovelock \& Gummesson, 2004), creation of value by actors in a value constellation as opposed to the traditional value chain (Normann, 2001; Normann \& Ramírez, 1993) and the relational traits of the service encounter (Grönroos, 2001).

The turn of the millennium marked the beginning of the Creating Language phase in service research (Briscoe et al., 2012). Nearly two decades after the IHIP, the views converged to give rise to a new service (dominant) logic for marketing (Grönroos, 2006; Vargo \& Lusch, 2004a), where the fundamental basis of economic exchange is service provision rather than goods. Service logic frames service as a perspective on value cocreation (Edvardsson et al., 2005). There are two distinct streams of literature that underpin this new logic: service logic (SL) (Grönroos, 2006, 2008) and 
service-dominant logic (Vargo \& Lusch, 2004a, 2008). SL positions the study of services directly in their marketing context (Grönroos, 2006). It focuses on interaction between the provider and customer as the basis for customers' value cocreation activities (Grönroos \& Ravald, 2011; Grönroos \& Voima, 2013). SDL distinguishes between 'service' as a fundamental activity of economic exchange, and 'services' as a segment of market offerings in contrast to goods (Vargo \& Lusch, 2004b). In this SDL view, service is broadly defined as the integration of resources for the benefit of another actor (Vargo \& Lusch, 2008). The main focus is on resource integration by actors in a value constellation (Normann \& Ramírez, 1993) or a service system (Maglio et al., 2006) to co-create value and new potential resources (Lusch \& Vargo, 2014). Value is defined uniquely and phenomenologically by the beneficiary (i.e., the person benefitting from the service) on the basis of value-in-use (Vargo \& Lusch, 2008; Vargo, Lusch, Akaka \& He, 2010). Such value cannot be delivered but only offered through value propositions (Vargo \& Lusch, 2016). As SDL evolved, the focus has shifted toward service ecosystems as the context and unit of analysis for value cocreation (Akaka \& Vargo, 2015; Vargo \& Akaka, 2012; Vargo \& Lusch, 2011, 2016). However, SDL is at a meta-theoretical level of abstraction, which makes it harder to directly apply to more practical inquiries (Vargo, Koskela-Huotari, \& Vink, 2020). The work in this thesis adopts an overarching service logic perspective with a focus on value-inuse. While SDL is highly abstracted (Wetter-Edman, 2009) and its conceptualisation of value cocreation has been critiqued as unsuitable for analytical purposes (Grönroos \& Voima, 2013), I draw on this perspective to inform my work as it provides a more systemic view than SL.

\subsubsection{The Service Shift to Systems}

Systems thinking is a perspective that recognises systems as assemblages of components that are all interconnected and essential, and whose interrelationships are at least as important as the components themselves (Norman \& Stappers, 2015). While systems theory is not new, there has 


\section{Chapter 2}

been a growing interest in the field of business and service management. The last few decades have seen a shift in service research from dyadic interactions to many-to-many interactions (Gummesson, 2008) among actors in value networks (Allee, 2002; Kothandaraman \& Wilson, 2001) occurring within a service system (Mele \& Polese, 2011). SDL has played a role in extending the view of service to a systems perspective (Vargo \& Lusch, 2016). Multiple definitions of service systems have been offered over the years. Service science defines service systems as "a configuration of people, technologies, and other resources that interact with other service systems to create mutual value” (Maglio et al., 2009, p. 395). Service systems are distinct from other systems as they are crucially dependent on sharing capabilities among other entities to create joint value (Maglio et al., 2015). Recently, there has been a turn to biological systems as an underlying metaphor for insights to explain and understand this phenomenon (Mars, Bronstein \& Lusch, 2012). A service ecosystem can be defined as a "relatively self-contained, self-adjusting system of resource-integrating actors connected by shared institutional logics and mutual value creation through service exchange" (Vargo \& Akaka, 2012, p. 207). Thus, value cocreation is coordinated through actor-generated institutions and institutional arrangements. However, this definition can obscure the intentionality, aspiration to a greater good and agency of actors evident in service systems (Mars et al., 2012). It also favours mutualism, at the risk of overlooking other forms of systems relationships such as competition, predation and commensalism (ibid). An emerging body of literature shows how service exchange can sometimes also result in negative value outcomes for some actors due to trade-offs, misuse and misintegration of resources (Laud et al., 2019; Plé \& Chumpitaz Cáceres, 2010). Further, different actors' value determination and experience across system levels are contested (Helkkula, Linna, \& Kelleher, 2013). The variety of actors and functions embedded in the ecosystem also influence the emergence of organisational hierarchy and structure (Mars et al., 2012). Despite these limitations, the ecosystem metaphor is useful to encourage systems thinking. 
Using the ecosystems metaphor also results in adopting analogous vocabulary, to understand and explain service system phenomena (Mars et al., 2012). Resilience is one such concept that has been touched upon in discussions of service systems (Frow et al., 2014; Lusch \& Spohrer, 2012). Some researchers have specifically called for attention to the resiliency of service systems (Lusch et al., 2016; Lusch \& Spohrer, 2012) and how they might be designed (Maglio et al., 2015). A targeted literature search through all years of the top six Service Journals (see Paper II for detailed methodology) - Journal of Service Management ${ }^{4}$, Journal of Services Marketing, Journal of Service Research, Journal of Service Theory and Practice ${ }^{5}$, Service Industries Journal and Service Science - yielded 17 papers that discussed resilience (see Table 2.1).

Table 2.1: Resilience focus and extracted definitions from literature in the six top service journals

\begin{tabular}{|c|c|c|c|}
\hline Author(s), Year & $\begin{array}{l}\text { Resilience } \\
\text { focus }\end{array}$ & Paper Type & Definition of Resilience \\
\hline $\begin{array}{l}\text { Borchert and } \\
\text { Mattoo (2010) }\end{array}$ & $\begin{array}{l}\text { Economic } \\
\text { resilience }\end{array}$ & $\begin{array}{l}\text { Descriptive } \\
\text { analysis }\end{array}$ & $\begin{array}{l}\text { Not provided. It refers to resilience as } \\
\text { the property of a specific economic } \\
\text { sector (services). }\end{array}$ \\
\hline $\begin{array}{l}\text { Navarro- } \\
\text { Espigares, } \\
\text { Martín-Segura, } \\
\text { and } \\
\text { Hernández- } \\
\text { Torres (2012) }\end{array}$ & $\begin{array}{l}\text { Economic } \\
\text { resilience }\end{array}$ & $\begin{array}{l}\text { Empirical } \\
\text { Quantitative }\end{array}$ & $\begin{array}{l}\text { Builds on the so-called engineering } \\
\text { resilience, concentrates on the stability } \\
\text { of a system near an equilibrium or steady } \\
\text { state (Holling, 1973). }\end{array}$ \\
\hline $\begin{array}{l}\text { Akgün, Keskin, } \\
\text { and Koçak Alan } \\
\text { (2017) }\end{array}$ & $\begin{array}{l}\text { Emotional } \\
\text { resilience }\end{array}$ & $\begin{array}{l}\text { Empirical } \\
\text { Quantitative }\end{array}$ & Not provided. \\
\hline $\begin{array}{l}\text { Azab et al. } \\
(2018)\end{array}$ & $\begin{array}{l}\text { Emotional } \\
\text { resilience }\end{array}$ & $\begin{array}{l}\text { Empirical } \\
\text { Quantitative }\end{array}$ & $\begin{array}{l}\text { Defined as "when beset by problems and } \\
\text { adversity, sustaining and bouncing back }\end{array}$ \\
\hline
\end{tabular}

\footnotetext{
${ }^{4}$ Formerly International Journal of Service Industry Management

${ }^{5}$ Formerly Managing Service Quality
} 


\begin{tabular}{|c|c|c|c|}
\hline Author(s), Year & $\begin{array}{l}\text { Resilience } \\
\text { focus }\end{array}$ & Paper Type & Definition of Resilience \\
\hline & & & $\begin{array}{l}\text { and even beyond (resilience) to attain } \\
\text { success" according to Luthans, Youssef, } \\
\text { and Avolio }(2007, \text { p. } 3) \text {. }\end{array}$ \\
\hline $\begin{array}{l}\text { Anasori, } \\
\text { Bayighomog, } \\
\text { and Tanova } \\
\text { (2019) }\end{array}$ & $\begin{array}{l}\text { Emotional } \\
\text { resilience }\end{array}$ & $\begin{array}{l}\text { Empirical } \\
\text { Quantitative }\end{array}$ & $\begin{array}{l}\text { Defined as "when beset by problems and } \\
\text { adversity, sustaining and bouncing back } \\
\text { and even beyond (resilience) to attain } \\
\text { success" according to Luthans et al. } \\
\text { (2007, p. 3). }\end{array}$ \\
\hline $\begin{array}{l}\text { Akgün, Erdil, } \\
\text { Keskin, and } \\
\text { Muceldilli } \\
(2016)\end{array}$ & $\begin{array}{l}\text { Individual } \\
\text { resilience/ } \\
\text { Resilience of } \\
\text { connections }\end{array}$ & $\begin{array}{l}\text { Empirical } \\
\text { Quantitative }\end{array}$ & Not provided. \\
\hline $\begin{array}{l}\text { Senbeto and } \\
\text { Hon (2020) }\end{array}$ & $\begin{array}{l}\text { Individual and } \\
\text { organisational } \\
\text { resilience }\end{array}$ & $\begin{array}{l}\text { Empirical } \\
\text { Quantitative }\end{array}$ & $\begin{array}{l}\text { Individual resilience can be conceived as } \\
\text { either a personal trait - a person has } \\
\text { inherited psychological capacity - or as a } \\
\text { capacity that a person can develop } \\
\text { through training or person-environment } \\
\text { interactions (Egeland, Carlson, \& } \\
\text { Sroufe, 1993). }\end{array}$ \\
\hline Varca (2004) & $\begin{array}{l}\text { Psychological } \\
\text { resilience }\end{array}$ & Conceptual & $\begin{array}{l}\text { The ability to recover normal energy and } \\
\text { enthusiasm rapidly, following a } \\
\text { discouraging situation. }\end{array}$ \\
\hline $\begin{array}{l}\text { Barnes and } \\
\text { Collier (2013) }\end{array}$ & $\begin{array}{l}\text { Psychological } \\
\text { resilience }\end{array}$ & $\begin{array}{l}\text { Empirical } \\
\text { Quantitative }\end{array}$ & $\begin{array}{l}\text { Not provided. It refers to resilience as } \\
\text { part of the construct under work } \\
\text { engagement. }\end{array}$ \\
\hline $\begin{array}{l}\text { Barnes, Collier, } \\
\text { and Robinson } \\
\text { (2014) }\end{array}$ & $\begin{array}{l}\text { Psychological } \\
\text { resilience }\end{array}$ & $\begin{array}{l}\text { Empirical } \\
\text { Quantitative }\end{array}$ & $\begin{array}{l}\text { Defined as "when beset by problems and } \\
\text { adversity, sustaining and bouncing back } \\
\text { and even beyond (resilience) to attain } \\
\text { success" according to Luthans et al. } \\
(2007, \text { p. 3). }\end{array}$ \\
\hline Loomba (2017) & $\begin{array}{l}\text { Psychological } \\
\text { resilience }\end{array}$ & Conceptual & $\begin{array}{l}\text { An ability of being unfazed by } \\
\text { considerable challenges in life, } \\
\text { consistently overcoming them and } \\
\text { bouncing back. }\end{array}$ \\
\hline $\begin{array}{l}\text { Shneikat and } \\
\text { Ryan (2017) }\end{array}$ & $\begin{array}{l}\text { Psychological } \\
\text { resilience }\end{array}$ & Descriptive & $\begin{array}{l}\text { Characterized by the ability to cope } \\
\text { effectively, recover and maintain an } \\
\text { equilibrium in spite of traumatic life } \\
\text { events. }\end{array}$ \\
\hline
\end{tabular}




\begin{tabular}{|c|c|c|c|}
\hline Author(s), Year & $\begin{array}{l}\text { Resilience } \\
\text { focus }\end{array}$ & Paper Type & Definition of Resilience \\
\hline $\begin{array}{l}\text { Gupta, } \\
\text { Shaheen, and } \\
\text { Das (2018) }\end{array}$ & $\begin{array}{l}\text { Psychological } \\
\text { resilience }\end{array}$ & $\begin{array}{l}\text { Empirical } \\
\text { Quantitative }\end{array}$ & $\begin{array}{l}\text { Defined as "when beset by problems and } \\
\text { adversity, sustaining and bouncing back } \\
\text { and even beyond (resilience) to attain } \\
\text { success" according to Luthans et al. } \\
\text { (2007, p. 3). }\end{array}$ \\
\hline $\begin{array}{l}\text { Baron et al. } \\
(2005)\end{array}$ & Service sector & Conceptual & $\begin{array}{l}\text { Not provided. It uses the term resilience } \\
\text { in reference to a crisis. }\end{array}$ \\
\hline $\begin{array}{l}\text { Lusch et al. } \\
(2016)\end{array}$ & $\begin{array}{l}\text { Service } \\
(\text { Eco)System } \\
\text { resilience }\end{array}$ & Conceptual & Not provided. \\
\hline $\begin{array}{l}\text { Maglio et al. } \\
(2015)\end{array}$ & $\begin{array}{l}\text { Service system } \\
\text { resilience }\end{array}$ & Conceptual & $\begin{array}{l}\text { Resilience is "the ability to prepare and } \\
\text { plan for, absorb, recover from, or more } \\
\text { successfully adapt to actual or potential } \\
\text { adverse events" (Committee on } \\
\text { Increasing National Resilience to } \\
\text { Hazards and Disasters 2011, p. 1). }\end{array}$ \\
\hline $\begin{array}{l}\text { Cheung et al. } \\
\text { (2017) }\end{array}$ & $\begin{array}{l}\text { Social resilience } \\
\text { (community } \\
\text { resilience) }\end{array}$ & $\begin{array}{l}\text { Empirical } \\
\text { Qualitative } \\
\text { (Embedded } \\
\text { Case Studies) }\end{array}$ & $\begin{array}{l}\text { Community Resilience has seven factors: } \\
\text { Bonding Social Capital, Bridging Social } \\
\text { Capital, Linking Social Capital, Social } \\
\text { Cohesion, Preparedness, Collective } \\
\text { Efficacy and Neighborliness (Norris et } \\
\text { al., 2008). }\end{array}$ \\
\hline
\end{tabular}

Several things stand out here. First, the majority of resilience papers concern individual resilience as a psychological or emotional capacity. These pre-dominantly quantitative studies focus on frontline staff and organisational employees' resilience as a personal trait or capacity. The definitions are correspondingly constructed in relation to these individual qualities rendering them unsuitable for understanding resilience at a systemic level. Amongst all the papers only two conceptual papers focus on system resilience. Second, all usages of resilience stress the importance of recovery, bouncing back and to some extent adapting to adverse events or crises. This view assumes that resilience manifests mostly as a response to a crisis, adversity or some kind of disruption. This discounts the possibility 


\section{Chapter 2}

of recognising or understanding how resilience might manifest as an individual flourishes in more benign conditions (Seligman \& Csikszentmihalyi, 2014). Third, the extant views on resilience emphasise bouncing back to an equilibrium state. This is also evident in other service literature which assume an equilibrium state (Frow et al., 2014; NavarroEspigares et al., 2012; Van Riel et al., 2019). This is problematic in two ways. One it suggests bouncing back to the existing state as desirable which might not necessarily be true nor feasible in the face of change. Two, even though one definition suggests bouncing forward, it still assumes an equilibrium state of stability in the new state. This might also not hold true in all cases of changes. Thus, while resilience has a well-defined understanding at the individual level, there is a need for a better understanding and development of resilience as a concept at the system level that is more robust and comprehensive.

\subsection{Tracing the Evolution of Service Design}

The theoretical underpinnings of Service Design ${ }^{6}$ span a range of academic fields from design to management (Karpen et al., 2017). This fragmentation makes solid theoretical grounding of Service Design a difficult task, with the evolving conceptualisations of service and design shaping the way service design has been conceived of and understood over time (Sangiorgi \& Prendiville, 2014). This section traces the development of Service Design in the service marketing and design literature streams.

\subsubsection{Service Design in New Service Development (NSD)}

The Walking Erect period between 1986 to 1992 saw services marketing being accepted fully as a discipline in its own right (Briscoe et al., 2012) with research spanning the design and management of service encounters

6 For clarity, 'Service Design' or SD in capital letters is used to describe the discipline and distinguish it from 'service design' as a phase in New Service Development (NSD). 
(Bitner, Booms \& Tetreault, 1990), to the role of intangibles and the physical environment in the customer's evaluation of the service (Bitner, 1992). The shift in the understanding of service away from goods-dominant logic spurred research on New Service Development (NSD), which drew heavily on existing new product development (NPD) literature (Biemans, Griffin, \& Moenaert, 2016; Edvardsson, Haglund, \& Mattsson, 1995). Several researchers discussed distinguishing factors of successful services and development process models (Bowers, 1986; Cooper \& de Brentani, 1991; de Brentani, 1989; Scheuing \& Johnson, 1989). Service engineering, with a more technical-methodological approach, was developed almost in parallel to NSD in the mid-nineties in Germany and Israel (Bullinger, Fähnrich, \& Meiren, 2003). It utilises engineering tools and methods for the design and development of innovative services. However, NSD gained more traction in service research over the years.

Within service marketing, the roots of service design can be traced back to the work of Shostack $(1982,1984)$ who pointed out the pervasiveness of poorly planned services and the need for a more rational, systematic approach to the design, development and control of services. To address this need, she put forth the service blueprint as a method for visualising the processes of creating and managing services (Shostack, 1982, 1984). Initial NSD literature also pointed to the lack of service designers (Gummesson, 1989) and the absence of a service design tradition, where the process is informed by those with a thorough understanding of the consumer needs (Edvardsson et al., 1995). Early service development concepts have been derived from a quality management perspective (Edvardsson \& Olsson, 1996), wherein design is understood as one stage in the process of NSD or in the redesign of an existing service (Alam \& Perry, 2002; Edvardsson, 1997; Scheuing \& Johnson, 1989). When designing for quality in services, the specification of the service concept, service process and service system is the main task for service development, with the understanding that this entails creating the right pre-requisites (Edvardsson \& Olsson, 1996). Developing the service concept became crucial in service design planning 


\section{Chapter 2}

(Goldstein, Johnston, Duffy, \& Rao, 2002) with customer involvement recommended in the idea generation, service design and service-testing phases (Alam \& Perry, 2002). The underpinning product logic is evident in the focus on implementation as a separate phase after design (Overkamp \& Holmlid, 2016; Yu \& Sangiorgi, 2014) and the emphasis on the design of the process to achieve right output of the service (Blomkvist, 2014). Most NSD models appear as linear and sequential with stage-gate processes (Alam \& Perry, 2002; Scheuing \& Johnson, 1989), although circular models (Johnson, Menor, Roth \& Chase, 2000) and non-sequenced suggestions (Holmlid \& Evenson, 2007; Holmlid, Mattelmäki, Visser, \& Vaajakallio, 2015) do exist. However, these traditional approaches end with the launch and do not provide methods and strategies for continued development (Holmlid, 2012, 2014; Yu \& Sangiorgi, 2018b). While improvisation and creativity are recognised as complimentary to the development process, no concrete direction is provided (Edvardsson et al., 1995).

Collectively, this research has advanced knowledge on how services are designed and developed. However, in this context, the meaning of service design is mostly obscured as part of a process (Yu \& Sangiorgi, 2014) with an emphasis on planning and control (Holmlid, Wetter-Edman, \& Edvardsson, 2017) focussing on new services as an outcome (Edvardsson et al., 1995).

\subsubsection{Service Design as an Approach}

Almost in parallel, while design in NSD was developing in the service marketing field, Service Design (SD) emerged as a practice in the 90 s within the design discipline, offering an outside-in approach to service development and innovation, with a focus on experiential value (Mager, 2009; Wetter-Edman et al., 2014). Under the 'new design agenda', Service Design became accepted as a profession, with Livework opening as the first service design agency (Sangiorgi \& Prendiville, 2014). SD represents a human-centred, creative, iterative approach to the creation of new services (Blomkvist et al., 2010). It has been described as an outside-in perspective 
on service development, positioned relative to industrial and interaction design (Holmlid, 2007; Holmlid \& Evenson, 2008; Sangiorgi \& Clark, 2004); as design of interactions and product service systems (Pacenti \& Sangiorgi, 2010); as design of people (Penin \& Tonkinwise, 2009) and as a meta activity (Dubberly \& Evenson, 2010).

Irrespective of domains, the design process on a general level remains quite similar. Although such process models acknowledge the iterative nature of design, they are often presented as linear, phased models to support understanding both in practice circles and academic discourse (see e.g. Aguirre, Agudelo, and Romm (2017); Costa, Patrício, and Morelli (2018); Stickdorn et al. (2011); Yu and Sangiorgi (2018b)). One of the most popular models is the Double Diamond process developed by the Design Council (2007). The two diamonds represent sub-processes of exploring the breadth and depth of an issue (i.e., divergent thinking) and taking selective action (i.e., convergent thinking). The discovery phase is primarily about (design) research that helps identify user needs without making assumptions. The definition stage entails interpretation of these needs as insights and alignment of stakeholder objectives. The next generative stage involves development of alternatives. These alternatives are tested, refined and narrowed down to be delivered as a final solution.

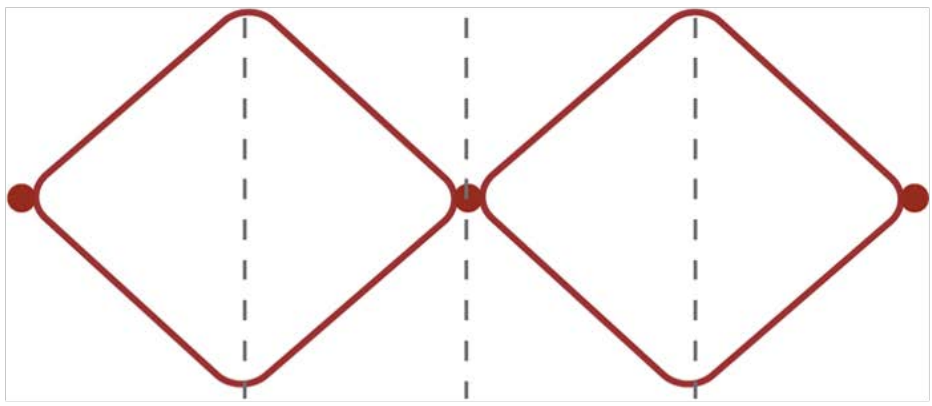

Discover Define Develop Deliver

Figure 2.1: The Double Diamond process adapted from Design Council, UK 


\section{Chapter 2}

Long considered as the bible of service design, the book This is Service Design Thinking (2011), offers five principles that define service design thinking: user-centred, co-creative, sequencing, evidencing, and holistic. User-centred refers to service designers' attitudes towards putting the user at the heart of the design process (Holmlid, 2009; Segelström \& Holmlid, 2015). This requires the capacity to empathise with customers, understanding their genuine needs and expectations (Fayard, Stigliani and Bechky, 2017). Co-creative refers to the service designers' belief that all relevant stakeholders need to be involved in the service design process (Holmlid et al., 2015; Sanders \& Stappers, 2008). Service design involves taking a holistic perspective (Fayard et al., 2017; Stickdorn et al., 2011), requiring the consideration of all elements of a service at varying levels. Sequencing refers to the very nature of services as sequences of interrelated actions and events; the design of a service requires the orchestration of such sequences (Følstad \& Kvale, 2018; Koivisto, 2009). Evidencing refers to service designers' tendency in practice to evidence intangible elements of the service through visualisation and prototyping (Halvorsrud, Kvale, \& Følstad, 2016). Service research scholars (Karpen et al., 2017) have identified six service design principles - design as human- and meaningcentred, co-creative and inclusive, transformative and betterment-oriented, emergent and experimental, explicative and experientially explicit, and holistic and contextual, that echo those of Stickdorn and colleagues (2011).

Adopting a service perspective, Meroni and Sangiorgi (2011) propose 'design for services' considering the potential capacity to create the right conditions for interactions to happen; partially echoing the view of Edvardsson and Olsson (1996) of creating the right prerequisites of service. Kimbell (2011, p. 49) uses the term 'designing for services' as one way of looking at SD (see Figure 2.2), where "the purpose of designers' enquiry is to create and develop proposals for new kinds of value relation in a sociomaterial world". This view of service design is firmly rooted in the design tradition, where design can be variably interpreted as a product, process, and practice (Wetter-Edman, 2011). It builds on Simon's (1969, p. 111) idea 
of transforming "existing conditions into preferred ones". It recognises the inability to fully plan services and that designing for service is never complete (Garud, Jain, \& Tuertscher, 2008; Kimbell, 2011). This view is also apparent in the 'design-after-design' in participatory design, where some participation and design activities are deferred until after the project, to address challenges in designing beyond the specific project (Bjögvinsson, Ehn, \& Hillgren, 2012).

Ways of thinking about service

Products and services are different [IHIP]

Service as basis for economic exchange[S-D logic]
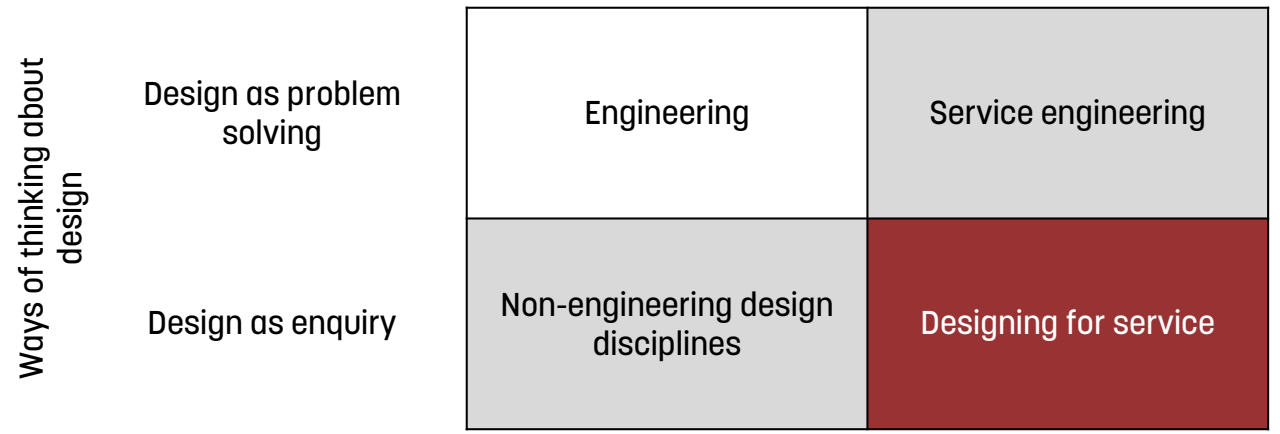

Figure 2.2: Approaches to Service Design according to Kimbell (2011). Adapted from Kimbell (2011, p. 45)

In the past decade, attempts have been made to bridge these two distinct but overlapping streams of literature in addressing NSD and value creation (Wetter-Edman, 2011; Wetter-Edman et al., 2014; Yu \& Sangiorgi, 2014, 2018b). Aligning with the design for service perspective, Service Design has been linked to service innovation, organisational change, enhancing customer experience, improvement of well-being and service inclusion (see e.g., Anderson, Nasr, and Rayburn (2018); Fisk et al. (2018); Kurtmollaiev, Fjuk, Pedersen, Clatworthy, and Kvale (2018); Patrício, Gustafsson, and Fisk (2018); Wetter-Edman (2014); Zomerdijk and Voss (2010)), giving a strong impetus to the uptake of service design. 


\subsubsection{The Object of Service Design}

The previous section has provided a background of the evolution of Service Design in the service and design disciplines. This section aims to shed light on the object of design in SD. Within the NSD stream of literature, the earliest reference to service material comes from the conceptualisation of service evidence (Shostack, 1977) as a combination of discrete tangible and intangible elements that make up the service. This was later incorporated into the service blueprint (Shostack, 1982, 1984) that focused on interactions in the service with evidence being one of the elements. Edvardsson and Olsson (1996) focused on the prerequisites to service - the service concept which captures what is to be done and how, the service process as a sequence of activities and the service system that provides the resources for these activities. The service system includes staff, customers, the physical/technical environment, and organisation and control. While they provide most detail on the service system development, they contradictorily describe the service system as static. This is problematic since the system consists of staff and customers that interact and these elements cannot be considered as static. A systems view is inherently dynamic, distinct from a structure which is static (Barile \& Saviano, 2011).

Early work separating the object of design as symbols, artefacts, interactions, and systems (Buchanan, 2001) continues to be significant in the design field. Others have also explored service as a design material (Blomkvist, Clatworthy, \& Holmlid, 2016; Clatworthy, 2011; Secomandi \& Snelders, 2011). While forming services, the material of service design fluctuates between the concrete and the abstract throughout the design process (Blomkvist, Clatworthy, et al., 2016). In their book chapter titled 'The object of service design', Kimbell and Blomberg (2017) attempt to answer the simple, yet perplexing question: What is it that service designers actually design? The authors identify three perspectives on understanding the object of service design: the service encounter, the value cocreating system, and the socio-material configuration, drawing on creative design 
and technology, social sciences with a focus on anthropology, and business and management to underpin their argument. The service encounter focuses on the experience customers have as they engage in interactions with the various touchpoints (Zomerdijk \& Voss, 2010) constituting the service. Service designers control the customer experience delivered over time by designing various touchpoints: "The tangible elements that make up the experience of using a certain service" (Fayard, et al., 2016, p. 6). To name a few, touchpoints can be physical spaces (e.g., retail shop), digital platforms (e.g., an app), or interactions with a call centre (e.g., a phone call). It is through encounters with all these different touchpoints that the service is enacted and the experience delivered. The service encounter emphasises what happens in the interactions between customers and providers. Thus, the focus is on multiple actors being (for example) users and customers, or staff and volunteers. Secomandi and Snelders (2011) argue that touchpoints remain poorly conceptualised in design, and critique their portrayal from a service evidence perspective as relegating design activity to mere accessorising. Instead, they argue for the material heterogeneity of the service interface as the object of design. In their review, they highlight that in each of the descriptions of the interface what stands out is not the intangibility but the heterogeneity of the service interface. This is contrast to the reported emphasis on intangibility as the most crucial of service from which others follow (Zeithaml et al., 1985).

The second object of service design, according to Kimbell and Blomberg (2017), is the value cocreating system. This is oriented toward the dynamic exchanges of resources and competences through which actors achieve certain outcomes for organisations and individuals. From this perspective, the focus on users and customers and their experiences is minimised, with an emphasis on the resource exchanges between entities within the system. Finally, the authors argue that the third object of service design is the sociomaterial configuration. This focuses on the dynamic arrangement of actors through practice, and emphasises the messiness and sociality of the service context. While the service encounter approach treats human actors as 


\section{Chapter 2}

having agency, the socio-material configuration approach argues that actors exert agency through their inter-relating. In other words, actors co-articulate the service in practice.

\subsubsection{The Practice(s) of Service Design}

A stream of research has explored how designers think and what designers do. Schön (1983) describes individual, professional practices as occurring through "reflection-in-action" while using judgement to reframe problems. Design as an emphatic and user-centred practice (Norman, 1998) has been forwarded as a creative (Dorst \& Cross, 2001) way of problem solving (Buchanan, 1992) to address wicked problems (Rittel \& Webber, 1973). Kimbell (2009b) highlights considering artefacts and experiences, assembling sets of relations, designing business models, making services tangible, and taking a holistic and detailed view of service as essential practices. In studying the specific activities of designers, others highlight visualising (Segelström, 2009) and prototyping (Blomkvist \& Holmlid, 2010) as integral to designers' work. After a rigorous review of service design literature, Karpen et al. (2017) identify six broad categories of interactive Service Design practices - representing, bonding, envisioning, reframing, aligning with brand values and condensing. The design practices of sensing surprise, perceiving multiples and embodying alternatives can significantly reshape actors' mental models (Vink, Edvardsson, WetterEdman, \& Tronvoll, 2018). In discussing how service design practices contribute to changing the rules of the game in healthcare, Vink and colleagues (2019) highlight five characteristics of service design practicesmultidisciplinary, experiential, participatory, experimental, and reflective. However, Kimbell (2009a, p. 10) also critiques the emphasis on designer's role. Rooted in Science and Technology studies, she offers an alternative conceptualisation of 'design-as-practice'. According to Kimbell (2009a) "design-as-practice mobilises a way of thinking about the work of designing that acknowledges that design practices are habitual, possibly rulegoverned, often shared, routinised, conscious or unconscious, and that they 
are embodied and situated." This acknowledges the role of the designers but also opens the design process to other stakeholders and their practices.

Design has also been referred to as a transformative practice that has the potential to create more sustainable services (Sangiorgi, 2010). More recently, transformation design was introduced by Burn and colleagues (2006) at Design Council to express design's expansive potential. They posit that designers' skills are intended to "transform the ways in which the public interacts with systems, services, organisations and policies" (Burns et al., 2006, p. 6). Designers and design researchers have been exploring the transformative role of design in triggering change in organisations (Junginger \& Sangiorgi, 2009) and communities (Meroni, 2007), and its potential for transforming public services (Parker \& Heapy, 2006). Transformations in service and design research have been mainly investigated from the perspective of shifts in organisational thinking and culture as a consequence of utilising or adopting service design (Bailey, 2012; Kurtmollaiev et al., 2018; Malmberg \& Wetter-Edman, 2016; WetterEdman \& Malmberg, 2016). While design research has studied such transformational aspects for some time, the idea of transformative service research aiming at improved wellbeing (Anderson \& Ostrom, 2015) is now beginning to take hold. This research area sees SD a complimentary perspective in achieving its transformational aims (Alkire et al., 2019; Anderson et al., 2018). Surprisingly, research on transformation in service literature is prioritised under 'servitization' i.e. the evolution of a goodsbased organisation to a service-led one (Ostrom et al., 2015). While this is important to help product-led companies' transition, it downplays the transitioning between differing service/business logics. The other characteristic of these existing transformation studies is the focus on organisational aspects of change while overlooking the larger system-related aspects of change and transformation. As service research attempts a shift to systems perspectives, there is a need to address system transformations, the role of service design in navigating such transformations and the practices associated with it. 


\subsubsection{Resilience in Design}

Within design literature, resilience has been explored in design for social innovation and sustainability streams of literature. Here, the focus has been on building and strengthening community resilience and designing environmentally, economically and socially sustainable outcomes. Scholars have applied a socio-technical systems perspective to understand the role of technical design interventions in strengthening community resilience (Baek et al., 2015). Design-led methods such as what-if scenario cards and playful triggers have been used to build community resilience for disaster preparedness (Akama, 2014). The red thread in building community resilience is the emphasis on actor engagement and the strengthening of social relationships. Further, Baek et al. (2015) introduced a framework to diagnose community resilience as an operational concept, by analysing the social relationships within the system network to design corresponding technical systems. The challenges in this project arose from defining the system state, which refers to a set of variables influencing resilience, and locating the critical thresholds, which is a border between two states. However, this approach too emphasises resilience as an abstract property that a system possesses. Despite this, architectural and planning design scholars have identified parallels between design and resilience relating to "the valorisation of processes over states, the loss of faith in 'planning', the ambivalent status of boundaries and interfaces, and open-ended political possibilities" (Cowley et al., 2018, p. 1). This indicates the prospect of fruitful dialogue between the complementary streams of SD and resilience.

\subsection{Chapter Summary}

In this chapter, I have given a brief history of the service research field and its evolution towards a service logic. I have highlighted the contemporary shift to service systems as a unit of analysis for value co-creation. I have problematised the existing view of resilience in service literature as limited mainly to the individual level, as an intrinsic trait or a property that 
manifests in response to crises, and as indicating the return to an existing equilibrium state. Therefore, I argue that there is a need for a better understanding and development of resilience as a concept at the system level that is more robust and comprehensive.

I contrast the design for service view with the traditional view of service design in New Service Development (see Table 2.2). I discuss the objects of service design viewed from varying perspectives, underline the transformative role of service design as a practice and briefly discuss resilience in design literature. As service research attempts a shift to systems perspectives, there is a need to address system transformations, the role of service design in navigating such transformations and the practices associated with it. To do so, it is necessary to understand the interplay of system dynamics across different scales and its impact on systems resilience.

Table 2.2: Summary comparison of Service Design perspectives

\begin{tabular}{|c|c|c|}
\hline & $\begin{array}{l}\text { New Service } \\
\text { Development (NSD) }\end{array}$ & Designing for Service \\
\hline Service view & Service as a market offering & $\begin{array}{l}\text { Service as a fundamental } \\
\text { activity of economic } \\
\text { exchange }\end{array}$ \\
\hline Service Design viewed as & $\begin{array}{l}\text { Stage or phase in process of } \\
\text { development }\end{array}$ & $\begin{array}{l}\text { Creative, iterative process } \\
\text { rooted in user's needs }\end{array}$ \\
\hline Emphasis on & Planning and control & $\begin{array}{l}\text { Creating conditions for } \\
\text { service to occur }\end{array}$ \\
\hline Outcomes & $\begin{array}{l}\text { Designed service as an end } \\
\text { product }\end{array}$ & $\begin{array}{l}\text { Developing proposals for } \\
\text { new kinds of value relations }\end{array}$ \\
\hline Value perspective & Value-in-exchange & Value-in-use \\
\hline Object of design & $\begin{array}{l}\text { Touchpoints and service } \\
\text { interface }\end{array}$ & $\begin{array}{l}\text { Socio-material } \\
\text { configurations }\end{array}$ \\
\hline
\end{tabular}





\section{Methodology}

It needs to be messy and heterogeneous, because that is the way it, research, actually is. And also, and more importantly, it needs to be messy because that is the way the largest part of the world is messy, unknowable in a regular and routinised way.

Unknowable, therefore, in ways that are definite or coherent.

[... ] Clarity doesn't help. Disciplined lack of clarity, this may be what we need.

- John Law

This chapter presents the methodology used in this thesis and an overview of the field engagements. The following sections describe the research approach, the methods, data collection and analyses applied in the individual studies, the research evaluation criteria and ethical considerations.

\subsection{Research Approach}

As the purpose of this research is exploratory, it adopts an emerging qualitative approach to inquiry. The basis for the exploration described in this thesis is three field engagements described in section 3.3. Qualitative research situates the observer in the world and consists of a set of interpretative practices that render the world visible (Denzin \& Lincoln, 2011). This thesis seeks to formulate an understanding of resilience in service systems and how service design can enable it. In doing so, it assumes a social constructivist worldview. This ontological view subscribes to the existence of multiple, varied realities. It affords more open-ended questions 


\section{Chapter 3}

where individuals can construct the meaning of situation typically through interactions with others and the negotiation of historical and cultural norms (Creswell \& Poth, 2018). I have undertaken this research in the context of healthcare, paying attention to the rules, norms and structures idiosyncratic to the setting. The epistemological view of the work is that knowledge is co-constructed between the researcher and researched and is shaped by individual experiences. This work relies on participants' perspectives and provides an interpretation of their subjective meanings.

I have attempted to have an abductive and reflexive approach (Alvesson \& Sköldberg, 2009) through a dialectical move between theory and the empirical context, careful interpretation and reflection. Theory has served to construct my understanding of Service Design and resilience in service research. This in turn has informed my understanding and interpretation of the empirical work as it has progressed. I also value the empirical "talkback" (Schön, 1983), the realisation in the analysis process, which enabled me to focus on both the interactional aspects and system-related issues. Barad (1996, p. 170) points out "as a matter of principle, there is no unambiguous way to differentiate between the "object" and the "agencies of observation" - no inherent/naturally occurring/ fixed/universal/Cartesian cut exists. Hence, observations do not refer to objects of an independent reality. "In my position as a researcher, I make this agential "cut" of what is under consideration and what is not, both in my reading of theory and the empirical material. As such, the work in this thesis reflects a situated, partial perspective (Haraway, 1988). I acknowledge that my own historical, cultural and personal experiences have shaped my interpretation and affect the results presented in this work.

\subsection{Data Collection Methods}

Interpretive research does not predefine dependent and independent variables, but focuses on the complexity of views and human sense-making in emergent situations (Kaplan \& Maxwell, 1994). 
Observation is one of the fundamental methods of data collection in qualitative research. The researcher notes phenomena of interest in a field setting through selected note-taking medium and records it for scientific purposes. In the field, my engagement has varied from 'participant as observer' wherein I have participated in the activity on site, to 'observer as participant' outside the group/activity under study without direct interaction, to 'complete observer' unnoticed by people under study. During observations I have made both descriptive and reflective notes including insights, confusions, ideas and initial interpretations. In all engagements, I have been introduced to all participants or at least a few key people in the field setting where I have been a complete observer. Every observation episode was followed up by writing a reflection or thick description.

An interview is considered as a social interaction where "knowledge is constructed in the interaction between interviewer and interviewee" (Brinkmann \& Kvale, 2015, p. 4). The main advantages of interview method of data collection are that:

- direct contact with informants often leads to focussed, constructive suggestions,

- detailed information on the phenomena of interest can be obtained, and

- it does not require a large number of informants to collect rich data.

In this thesis, I have conducted semi-structured interviews during my secondment at Healthcare Inc. and utilised an interview protocol consisting of four parts (See Appendix B). Other interview data accessed as part of the field engagements is treated as secondary data in the document category, since I was not the interviewer. While conducting the interviews care was taken to ensure the comfort of the informant and they were informed of the research purpose, how their data would be used, confidentiality, 


\section{Chapter 3}

anonymity and their right to withdraw. The interviews were recorded using multiple devices for obtaining both audio and video documentation.

This data is supplemented by documents in the form of official reports, organisational documents, official guidelines and other publicly available archival data. Project leaders have also maintained diaries and reflective notes, which I have accessed. Workshops have resulted in the production of several artefacts ranging from idea troves, journey maps, actor maps and service prototypes amongst others. In addition, audio-visual materials have supported the analysis as all settings have been photographed and where possible several activities have been audio and/or video recorded.

\subsection{Overview of Field Engagements}

For the purpose of readability, this section presents a comprehensive synopsis of the field engagements that have informed the work presented in this thesis in chronological order. Table 3.1 provides an overview of the data collection and analysis.

Table 3.1: Overview of Field Engagements

\begin{tabular}{|c|c|c|c|c|c|}
\hline $\begin{array}{l}\text { Engage- } \\
\text { ment } \\
\text { (Paper) }\end{array}$ & Focus & $\begin{array}{l}\text { Paper } \\
\text { Type }\end{array}$ & Method & $\begin{array}{l}\text { Data } \\
\text { Collection }\end{array}$ & $\begin{array}{l}\text { Data used } \\
\text { for }\end{array}$ \\
\hline $\begin{array}{l}\text { Chronically } \\
\text { Engaged } \\
2.0 \\
\text { (Paper IV) }\end{array}$ & $\begin{array}{l}\text { Understanding } \\
\text { variations and } \\
\text { their role in } \\
\text { service } \\
\text { development } \\
\text { through } \\
\text { prototyping }\end{array}$ & Empirical & $\begin{array}{l}\text { Participant } \\
\text { Observations, } \\
\text { Service } \\
\text { Desktop } \\
\text { Walk- } \\
\text { throughs, } \\
\text { Team } \\
\text { discussions }\end{array}$ & $\begin{array}{l}\text { Service } \\
\text { prototypes, } \\
\text { Video } \\
\text { recordings, } \\
\text { Audio } \\
\text { recordings, } \\
\text { Photographs, } \\
\text { Observation } \\
\text { notes, } \\
\text { Debrief notes }\end{array}$ & $\begin{array}{l}\text { Content } \\
\text { analysis of } \\
\text { transcripts } \\
\text { with } \\
\text { inductive } \\
\text { coding }\end{array}$ \\
\hline $\begin{array}{l}\text { Chronically } \\
\text { Engaged } \\
2.0 \\
\text { (Paper V) }\end{array}$ & $\begin{array}{l}\text { Development } \\
\text { of Perceived } \\
\text { Action } \\
\text { Potential (PAP) }\end{array}$ & $\begin{array}{l}\text { Concep- } \\
\text { tual }\end{array}$ & $\begin{array}{l}\text { Participant } \\
\text { Observations, } \\
\text { Reflection } \\
\text { films }\end{array}$ & $\begin{array}{l}\text { Observation } \\
\text { notes, Video } \\
\text { recordings }\end{array}$ & $\begin{array}{l}\text { Empirical } \\
\text { illustration }\end{array}$ \\
\hline
\end{tabular}




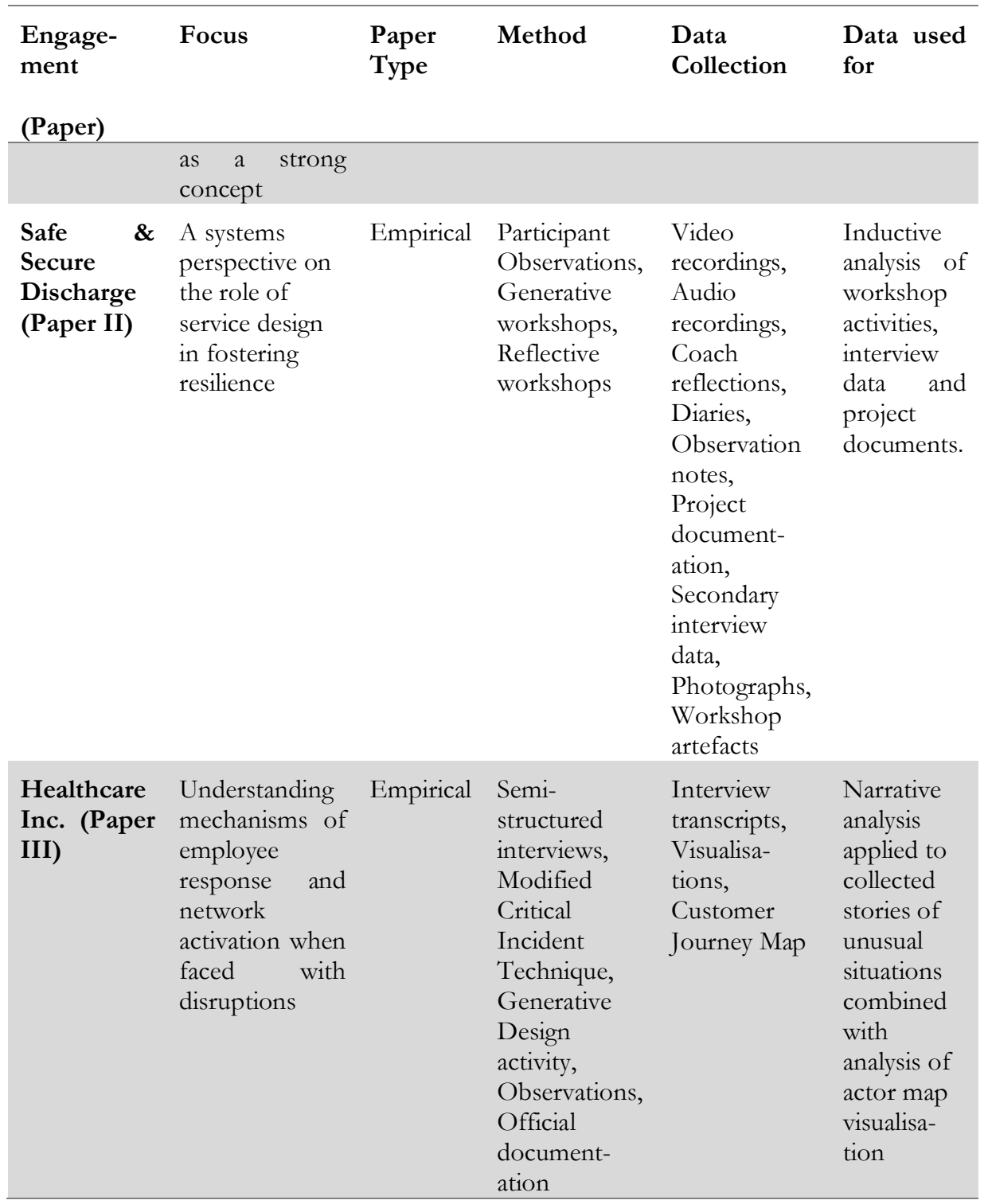

\subsubsection{Chronically Engaged 2.0 (SE: Kroniskt Engagerad 2.0)}

In fall 2014, the Sörmland County Council and the Primary Healthcare Centre (PHC) City, Eskilstuna, participated in a national project "Chronically Engaged". In the project, solutions were sought to create better conditions for chronically ill patients to manage their life situation 


\section{Chapter 3}

and contacts with the healthcare centre. Following this, the County Council decided on March 11, 2015 that a working methodology for person-centred care (PCC) should be introduced in the county council of Sörmland (LSLED15-0002-8). The new Patient Act also requires changed ways of working to strengthen the patient's position and opportunity for participation. The Chronically Engaged 2.0 (CE2) project aimed to seize and disseminate insights from the previous Chronically Engaged project to more care units and at the same time introduce person-centred care in participating units. Person-centred care in this context is defined as care where the patient is seen and respected as an equal partner and where care is based on the person's conditions, resources and hindrances. It also enables the person's participation in the design of care. Service Design as a method was used to gain a deep understanding of the users' (patients) needs and drive the project. The innovation model (see: https://innovationsguiden.se/) promoted by the Swedish Association of Local Authorities and Regions (SKL) was also used to support the improvement process. Figure 3.1 provides a visual timeline of the project.

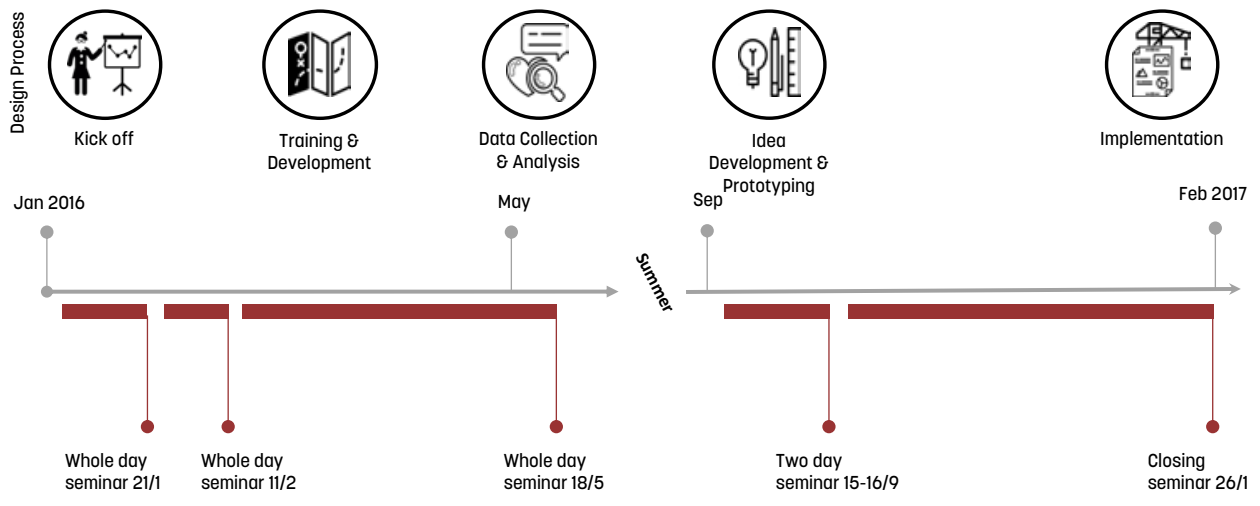

Figure 3.1: Chronically Engaged 2.0 Project Timeline

The project sought the following outcomes:

- that all staff involved in the project feel an increased ability to draw on patients and their close relatives as a continuous resource in care, 
- that participating patients in the project feel seen, heard and have been given the opportunity to contribute to the development of PCC.

- that the improvement methodology, solutions and tools developed in the project can be a model for the other county councils and the rest of Sweden.

\section{Participants and context}

In the Chronically Engaged 2.0 project, cross-professional teams from four PHCs in the county council of Sörmland, together with their patients, developed care processes to address the needs of chronically ill patients.), Diabetes (PHC A \& B), hypertension (PHC C) and Cardio-Obstructive Pulmonary Disease (COPD) (PHC D) were chosen as the focal chronic conditions at participating units. The project team consisted of a project leader, the co-ordinator for PCC and a hired service designer. Participating teams received training on PCC, improvement work and Service Design methods during five full-day seminars on four occasions. The seminars included time for hands-on practice of methods and reflection. I was roped in to actively work on the project in August 2016 as an extra resource through my secondment at Experio Lab, with whom the County Council of Sörmland has an established connection. My role in the project was framed as a design researcher who would contribute with service management and Service Design knowledge. This work also involved cofacilitation of a service prototyping workshop for the participating teams along with two senior researchers and the project leaders. Follow-up work to this session entailed giving constructive feedback and enabling participant reflection to refine their proposed service additions or changes.

The year-long project aimed at introducing patient-centred care through increased patient participation and dissemination of patient-centric ways of working, with Service Design guiding the project process. The teams were encouraged to have a designated project manager and set aside 1-2 hours per week for the project. To uncover patient needs, the units actively involved 121 patients through several activities such as interviews, diaries, 


\section{Chapter 3}

surveys, suggestion-boxes, open house, patient council, information meeting, cooking course, film making and seminars. A large number of quotes (approx. 390) were also collected in connection with patient visits, open houses, vaccination mingles or health checks. The material collected was formulated by the teams into comprehensive insights that highlighted patient needs concerning increased knowledge about self-care, increased accessibility and continuity in care, the importance of deferential treatment of patients in consultations and the inadequate attention to patients' mental health. Based on the insights, ideas were generated, and selected ideas were prototyped during the team seminar held between 15-16 September 2016. This session resulted in the development of tentative solutions that were tested in unit operations.

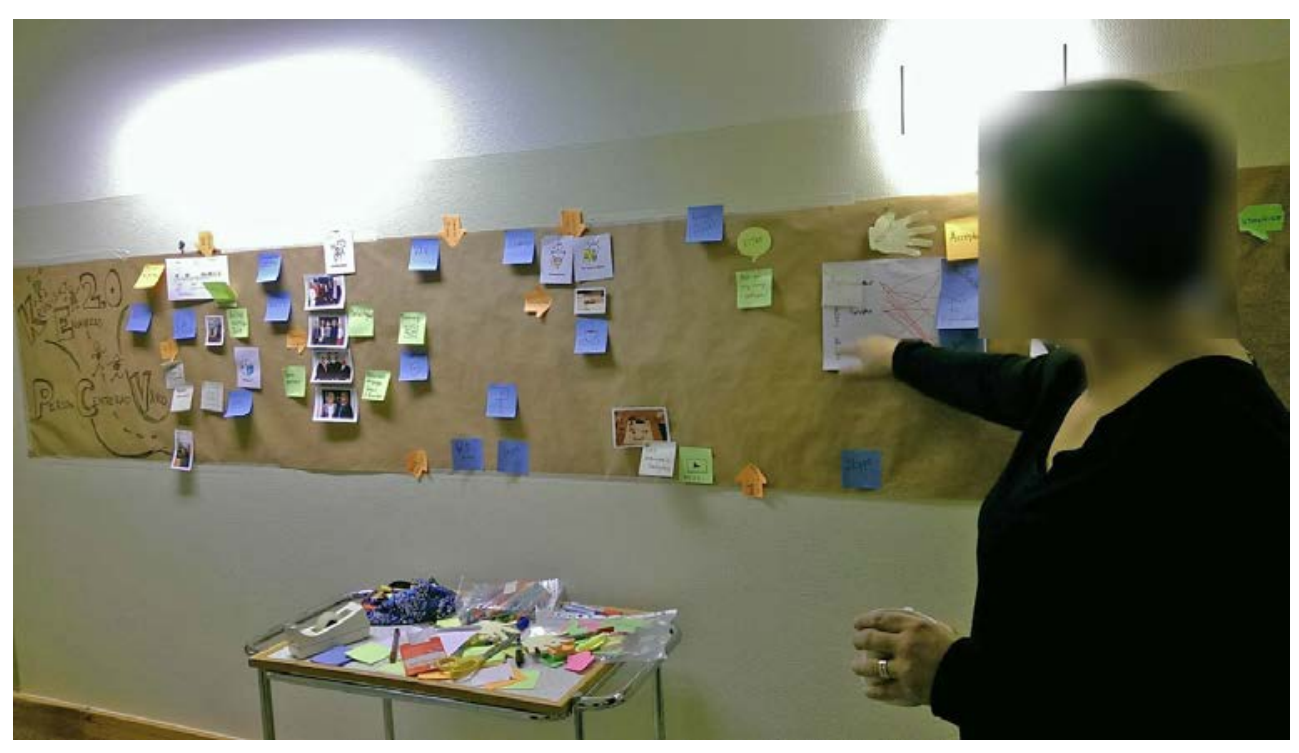

Figure 3.2: Mapping the overall CE2 project journey. Photo taken by author. 
For a detailed overview of participating teams and the prototyping workshop see Rodrigues and Holmlid (2017). In parallel with the team's work, the overall project team also worked on the production of three reflection films ${ }^{7}$ drawing on insights from the collected data (see Figure 3.2) and other PCC-related work being carried out in the County Council. I did not directly interact with any patients except on one occasion while documenting the cooking course aimed at diabetes patients.

\section{Data collection and analysis}

All four team presentations and discussions of the desktop walkthrough (Blomkvist, Fjuk, \& Sayapina, 2016) (seen in Figure 3.3) during the prototyping seminar were video recorded. Any ambiguous aspects were clarified in the discussions following the presentations. This was also complemented by workshop debriefing, observatory field notes and informal discussions with participants while they were fleshing out their prototypes. The workshops were held in Swedish. Hence, all files were transcribed verbatim in Swedish and translated to English by a native speaker. The transcripts were coded iteratively and qualitative content analysis was used (Graneheim \& Lundman, 2004). Content analysis is a flexible text analysis method that describes a category of analytic approaches ranging from intuitive, interpretive to systematic, strict textual analyses (Rosengren, 1981). The conventional content analysis method was chosen since it allows for the subjective interpretation of the context of various forms of text data (Hsieh \& Shannon, 2005) without enforcing preconceived categories. The results were then discussed from the perspective of the service logic framework (Grönroos \& Voima, 2013) and the types of variability were compared to the findings of Frei (2006). This approach is not be confused with the Grounded Theory method or phenomenology. While these approaches share a similar analytical method, content analysis

\footnotetext{
${ }^{7}$ See http://www.landstingetsormland.se/reflektionsfilm
} 
Chapter 3

falls short of theory development or providing a nuanced understanding of lived experience (Hsieh \& Shannon, 2005), neither of which was the purpose of this study.

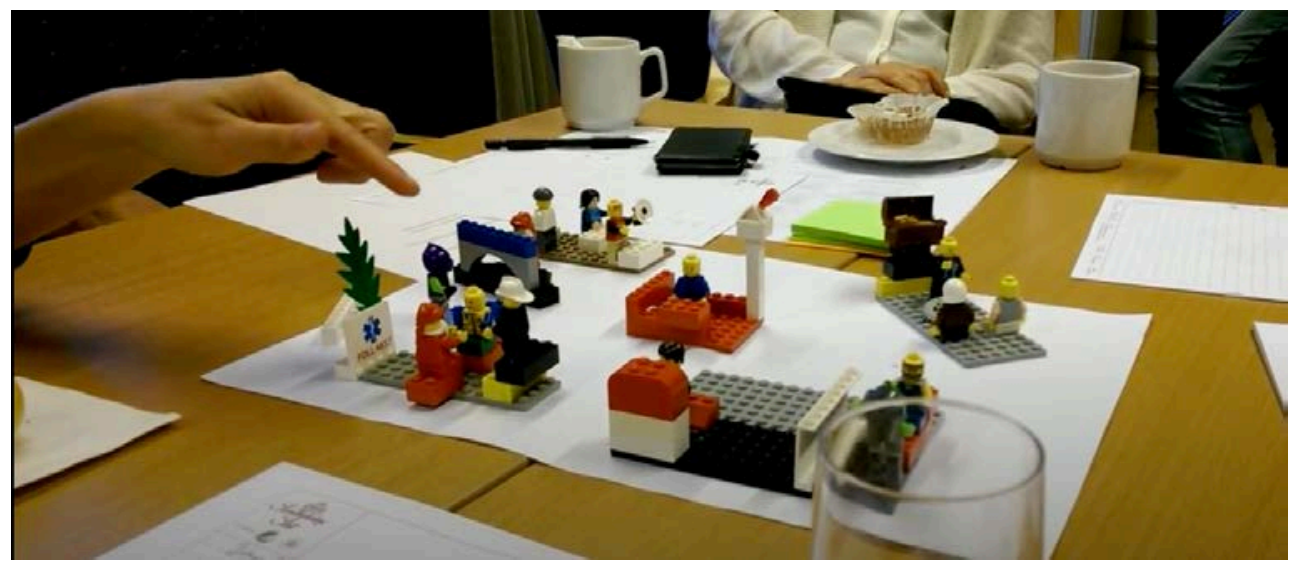

Figure 3.3: Prototype of service using the desktop walkthrough method. Screenshot of video taken by author.

\subsubsection{Safe \& Effective Discharge (SE: Trygg och Effektiv Utskrivning)}

The Safe \& Effective Discharge (SED) was an intervention research project carried out by the County Council of Sörmland at the regional level in Sweden in 2017. The project was initiated with the purpose of exploring the introduction and subsequent application of a new set of guidelines for the patient discharge process. These guidelines were developed locally in response to forthcoming government legislation directing the cooperation between different actors in public healthcare, including the county council and municipalities involved in the inpatient care and discharge processes. The new legislation is aimed at ensuring a patient-centred, safe and effective discharge process. Collaboration between these actors is imperative to ensure positive patient outcomes and experience post-hospitalisation. The regional guidelines propose ways to streamline the collaboration between the hospital inpatient care managed by the regional actors and posthospitalisation health and social care managed by the municipality. This 
implied considerable change in the staff's way of working. It included the introduction of the role of a coordination nurse who would serve as the point of contact for all actors involved in this process. The goal of this project was to develop person-centred approaches and routines through Service Design, and that these should be reflected in the guideline document. Service Design served as both an approach and methodology with the user's needs and experiences as its cornerstone. In this project, it was intentionally used to create and offer participants space for experimentation with new ways of thinking and doing. Figure 3.4 provides a visual timeline of the SED project.

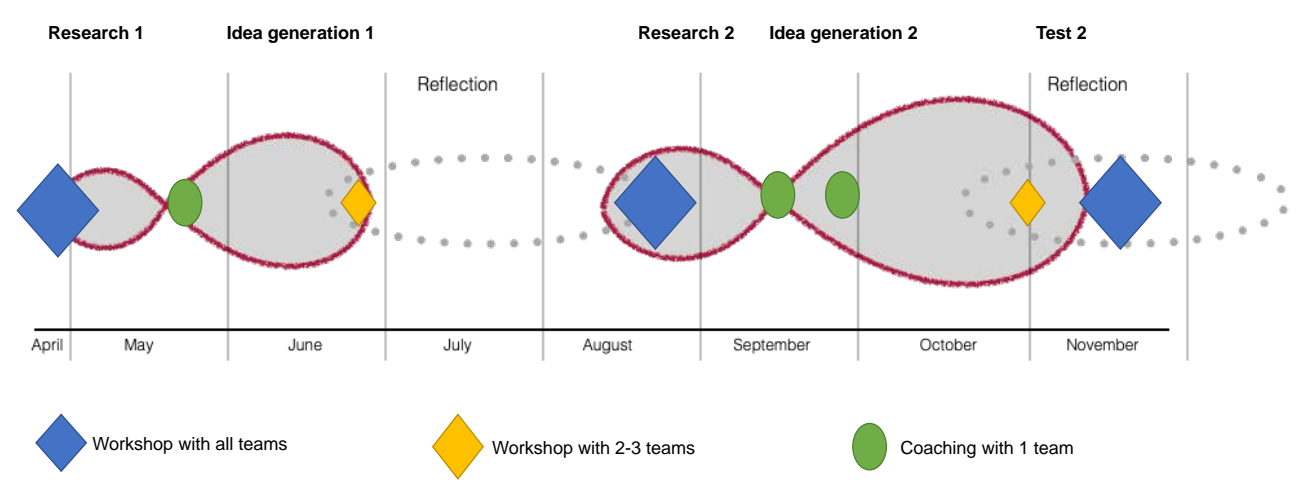

Figure 3.4: Safe \& Secure Return Home Project Timeline. Reproduced with permission from Katarina Wetter-Edman.

\section{Participants and context}

The intervention research project was led by a senior design researcher, assisted by another design researcher who planned and managed the complete process. They were supported by two coaches and two doctoral students including myself for the duration of the entire project. My participation in this project was an extension of my secondment at Experio Lab. In contrast with CE2, I was involved in the SED project from the start to finish. While primarily participating in the capacity of a design researcher, I contributed to workshop planning, facilitation, coaching, analysis and reflection activities. Spanning 8 months from April to November 2017, the project included 55 participants, in 8 teams, from more than 20 different 


\section{Chapter 3}

organisations associated with Sörmland's public sector entities. The project was planned to be conducted in two loops (see Figure 3.4) to enable iterative learning through repetition. At the first meeting, teams started out by framing an issue in relation to the discharge process. Following this they conducted exploratory user research, analysed their data and outlined their preliminary insights. This formed the basis for the actor-mapping exercise (modified from Čaić, Odekerken-Schröder, and Mahr (2018)) which was conducted in smaller sessions including 2-3 groups indicated by yellow diamonds in Figure 3.4. During this generative workshop (Sanders \& Stappers, 2012), the teams first mapped the existing service work processes and related system actors (Figure 3.5). In the next iteration, they mapped the reimagined service process informed by the guidelines and based on their insights (Figure 3.6).

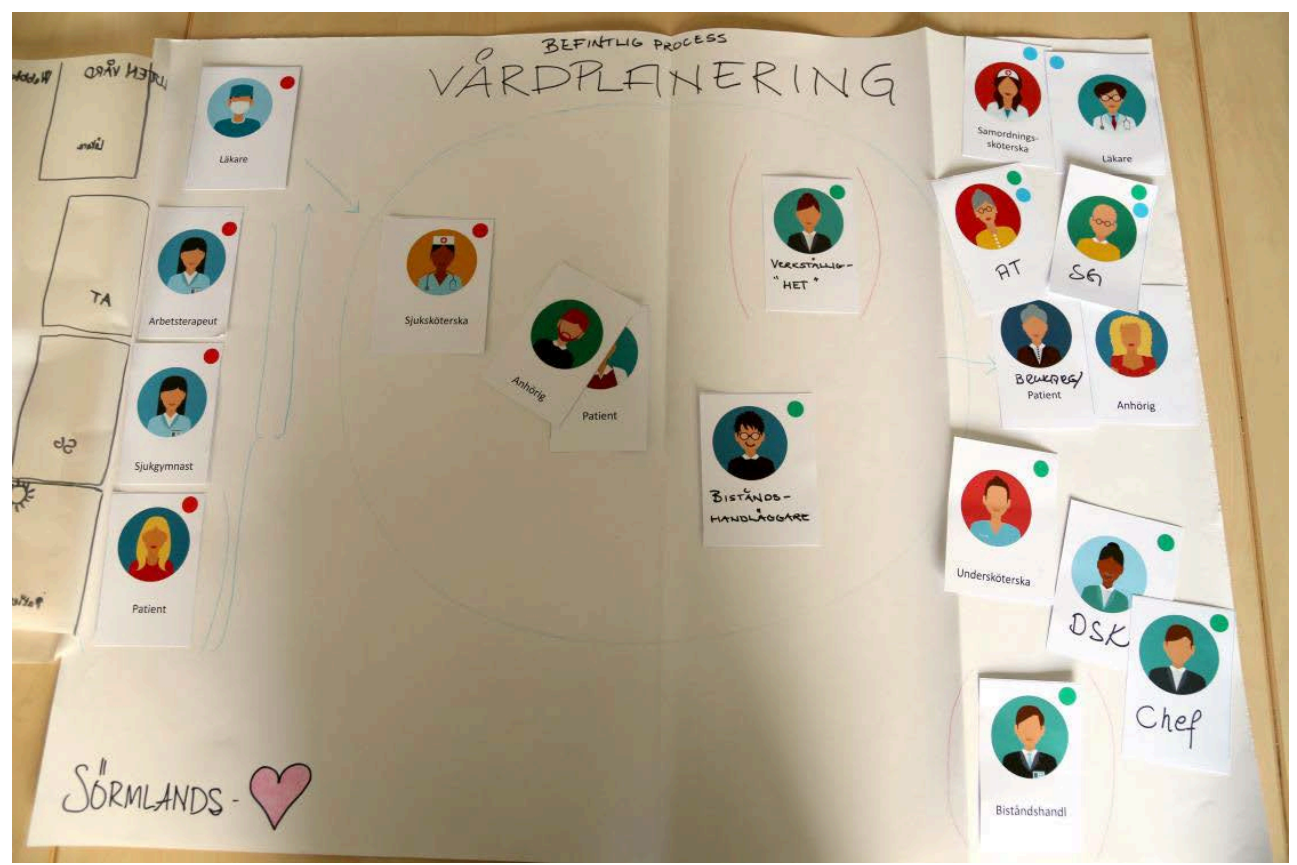

Figure 3.5: Generative Actor Mapping - The Status Quo. Photo taken by author.

The intention of the initial iteration was to reach a first prototyping stage. This was also the motivation for my participation and of primary interest to this research. However, due to unexpected difficulties in team formation 
and time restrictions this objective was not completely achieved. After the completion of the first loop, participants were given time to reflect on and make sense of the process and the insights they had gathered. During the second loop, participants repeated the process, building on their previous insights to refine the activities they undertook in the first loop. They used approaches and methods from Service Design to develop, adapt and/or find new solutions to routines, activities and flows in the discharge process that corresponded to the new guidelines, all the while maintaining a patientcentred perspective. The teams utilised prototyping techniques such as roleplay and service walkthrough (Blomkvist, 2012) to simulate their service ideas which advanced their understanding of future collaboration with other institutions. These prototyping sessions were conducted in smaller groups similar to the mapping exercise. In addition, teams also received coaching on-site or via Skype at several spaced intervals during the course of the project. For an overview of the workshop activities see Appendix C.

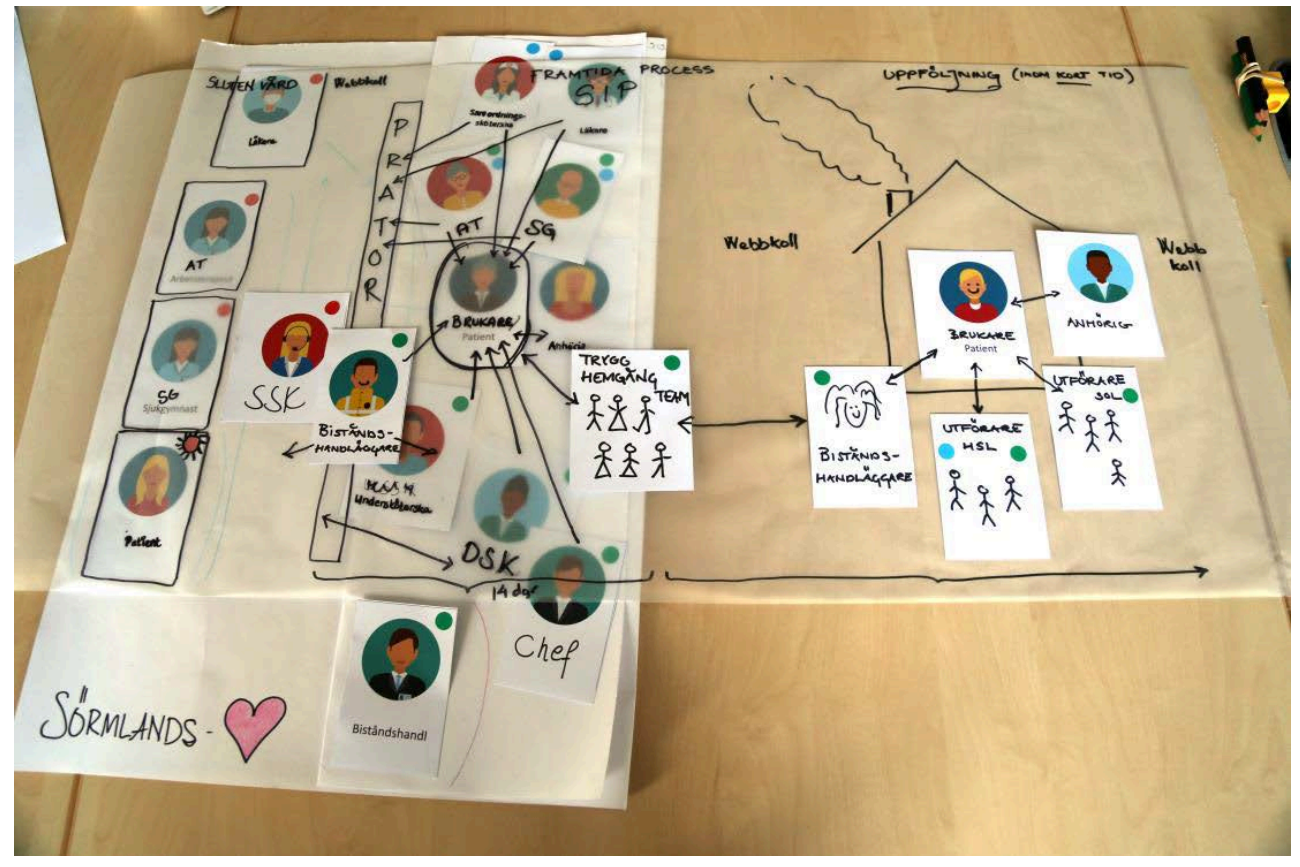

Figure 3.6: Generative Actor Mapping - The Imagined Future. Photo taken by author. 
Chapter 3

\section{Data collection and analysis}

From the project leader's perspective, this project utilised an action research approach with the intention to create a change (Cohen, Manion, Morrison, \& Morrison, 2007). I cannot however claim the same as I did not actively drive the research agenda for this project. For the purpose of this thesis, this project presented itself as an ethnographic opportunity to understand the use and role of design in affecting change at multiple system scales. Overall project data collected includes interviews with project participants, researcher diaries, written reflections of the core project group throughout the process, as well as audio, video and photographic documentation and participant observation of workshops, team coaching sessions and project research analysis sessions. A theoretical resilience lens to understanding transformations was applied to the project, resulting in the identification of practices that contribute to resilience and a framework for understanding the transition in this project. I did not directly interact with any patients during the course of the project. All data has been collected in Swedish but has been analysed and translated by researchers with Swedish as their native language.

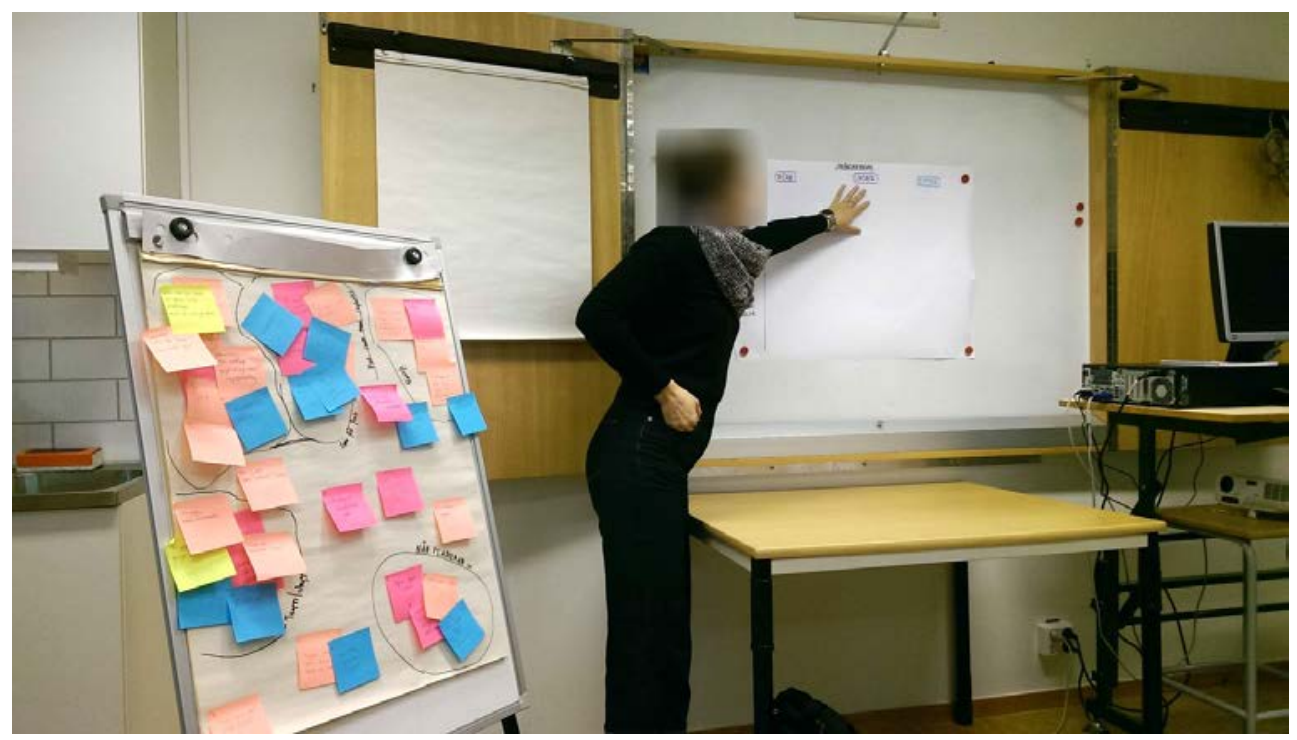

Figure 3.7: Analysis session with the teams. Photo taken by author. 


\subsubsection{Healthcare Inc.}

The collaboration with Healthcare Inc. was the outcome of my secondment at Politecnico di Milano (Polimi). The Design Manager had established contact with a professor at Polimi, who introduced us over a Skype meeting. Service Design was just starting to be incorporated at the organisation and she thought it would a mutually beneficial opportunity, where the organisation could serve as the field for research and I could contribute with my knowledge and support her design endeavours. My secondment lasted three months from April 2018 to June 2018. During this time, I spent four days a week at Healthcare Inc.

\section{Participants and context}

Healthcare Inc., a front-runner in primary, poly-ambulatory healthcare located in a large metropolitan European city, offered an exciting and different research context. At the time, the organisation had approximately 150 employees and 600 contracted doctors, paramedics and healthcare professionals spread over 16 polyclinics, a centralised call centre and the Head Office. An important distinction is that the organisation was intrinsically motivated to adopt a design approach without pressure from external actors. This adoption was being driven by the Chief Executive Officer who recognised the value of design. Unlike the public sector initiatives, I had engaged with earlier there was no defined project underway and the design work did not follow any predefined model or methodology. At Healthcare Inc., the medical staff who are crucial to the service are not in-house but contracted. In this case, the doctors who form the core of service provision serve a dual role as clients, indicating tensions in terms of balancing possibly conflicting interests and managing relationships. Based on the insights from previous research projects and due to time constraints, I chose to conduct an interview study. This was supplemented by participant observations at the Head Office, call centre and 6 clinics. For detailed overview of participants and procedure see Paper III. 


\section{Chapter 3}

\section{Data Collection and Analysis}

Semi-structured interviews using a modified Critical Incident Technique (Flanagan, 1954) were conducted with 10 informants. The interview protocol is provided under Appendix B. This was supplemented by a generative mapping activity where informants visualised the actors (and connections) involved in situations that deviated from the daily routine. The interviews were conducted in-situ at the informants' respective workplaces and lasted approximately 50 minutes on average. Narrative analysis was applied to the transcribed stories and an inductive coding approach was used. The result of the analysis was the identification of patterns of disruption, a ripple model that highlights how actor networks are activated in disruptive situations and the underlying tensions among actors responding to such situations. In addition, I maintained a research diary and have worked with the design team in mapping the customer journey, which has also been informed by observations conducted at the clinics. Due to company policy, I did not directly interact with any patients or contract medical staff during the course of my secondment.

\subsection{Research Evaluation}

Traditionally, research in the positivistic paradigms are evaluated based on their reliability and credibility. As these studies are often based on standardised research instruments, they are relatively easy and straight forward to assess. However, these criteria may not necessarily be strictly applicable to qualitative research (Merriam, 1998). Research scholars present several alternate perspectives on validation of qualitative studies (Creswell \& Poth, 2018; Lincoln \& Guba, 1985). In this section, the validation strategies and the transferability of the findings are presented for the reader. 


\subsubsection{Validation strategies}

Creswell and Poth (2018) recommend using at least two validation strategies to allow researchers to document and assess the accuracy of their studies and to enable the reader to evaluate the results. The validation strategies used in this research are as follows:

\section{Corroborating evidence through triangulation}

Triangulation involves gathering multiple perspectives on the same issue to gain a more holistic understanding of the phenomena and can include methodological, data, investigator and theoretical triangulation (Flick, 2018). It involves corroborating evidence from multiple data sources, methods, theories, investigators and is an important way to improve the credibility of qualitative research findings. In this thesis, I have used multiple methods spread over three different situated contexts to understand the phenomena in focus. Insights have been gathered and compared within and between engagements through observations, interviews, informal discussions, and constructed workshop artefacts. To support investigator triangulation, I discussed and received feedback on the personal and collective reflections of the engagements from a research perspective with all project leaders. Furthermore, one of my supervisors has been involved in the field doing observations and conducting interviews in both CE2 and SED but to a limited extent, which aids in combining different interpretations and perspectives in the study (Erickson \& Stull, 1998).

\section{Member checking or seeking participant feedback}

The interpretations of the empirical data were also validated through member checking (Creswell \& Poth, 2018). This is considered the most critical technique for establishing credibility (Lincoln \& Guba, 1985, p. 314). The preliminary interpretations were shared and discussed with project leaders, team members in CE2 and SED, and with key informants and the 


\section{Chapter 3}

Design Manager at Healthcare Inc. This was done in an iterative way during the secondments, and later again when collating data after the secondments had ended.

\section{Prolonged engagement and persistent observation}

While the sites for my research were driven by the defined secondments, I have nonetheless made field-based choices about what is salient to study given the focus and relevance for the purpose of the overall thesis. During my secondment at Experio Lab, I was co-located at the County Council's office in Eskilstuna with the project leaders for CE2. While officially my secondment lasted from February 2017 to May 2017, I have been engaged with the County Council effectively from August 2016 to November 2017 resulting in my following and participating in the both the CE2 and SED projects. During this time, I have built rapport with several actors across the County Council and SKL by visiting multiple primary healthcare centres across the region, attending PCC conferences, SKL conferences, seminars and informal discussions over fika with colleagues at the County Council to learn about the culture and context. I have also voluntarily contributed with my time, knowledge and research capability to two other projects Hälsotorget and DialogLab that are not included as part of this thesis.

At Healthcare Inc. my secondment was much shorter lasting only three months. During this time, I was almost always located at the Head Office of Healthcare Inc. which allowed me to be part of the daily activities. I rotated through the departments to get a better understanding of everyone's work practices in their natural setting. In addition, I also visited eight healthcare centres and met people at the call centre. I was included as part of all organisational activities including Friday strategy meetings which were only open to staff. On the more social side, I was also invited to the team building day for held for all staff. This, along with the move to the new Head Office and helping with the opening, helped establish rapport and trust over a short period. The extended time spent embedded within the 
field during all engagements has thus helped me gain a more holistic understanding of the site and its participants.

\section{Having a peer review or debriefing of the data and research process}

In referring to how Lincoln and Guba (1985) define a peer debriefer as a 'devil's advocate' Creswell and Poth (2018, p. 263) state that this individual "keeps the researcher honest; asks hard questions about methods, meanings and interpretations; and provides the opportunity for catharsis by sympathetically listening to the researcher's feelings". I am fortunate to have benefited from various 'devil's advocates' during the course of this thesis work including my supervisors, researchers within the SDIN network, the Experio Lab network, and other senior researchers in the local research group amongst others. In addition, several papers included in this thesis have also undergone a peer-review process.

\subsubsection{Transferability}

Transferability is analogous to external validity in quantitative research (Lincoln \& Guba, 1985). Generalisability refers to the extent to which one can apply the findings, results, conclusions from an account of a particular study to other individuals, times, settings or institutions than those directly studied (Maxwell \& Chmiel, 2014). This work does not claim generalisability. The subjectivity of the researcher poses a major challenge for the transferability of the research results, requiring thick descriptions to enhance transferability (Creswell \& Poth, 2018). I have chosen to provide detailed, thick descriptions of the individuals, settings, methods and timelines, to give the reader adequate information to judge the applicability of the results in other specific and different contexts, what is termed as reader generalisability (Misco, 2007). 


\section{Chapter 3}

\subsection{Ethical considerations}

As this research is part of the European Horizon 2020 Marie Skłodowska Curie Actions, all research activities required approval from an ethics board and an acknowledgement of research funding in all publications. Ethical approval was sought and granted for the CE2 and SED projects since they involved contact with patients. This was done by the project leaders. A research proposal was sent to the gatekeeper (Design Manager) at Healthcare Inc. and approval was sought locally from the CEO of the organisation. A research presentation was held on-site at the head office of Healthcare Inc. for the C-suite managers before I began any research activity. This was to ensure transparency and establish reciprocity in that I would contribute to ongoing design and quality improvement work as directed. Necessary permission has been obtained to reproduce the material that has been used in the different engagements that was not created by me.

I was formally introduced to all teams, participants, key organisational actors and informants in all engagements and my role and purpose were clarified to avoid any ambiguity. All participants were informed of the purpose of this research and whom the data would be shared with. Informed consent has been obtained from all participants whose data has been utilised in this thesis. Participants were given a copy of their informed consent with my official contact details and were informed of the confidentiality and their right to withdraw from the study at any time. None of the participants have contacted me to do so at the time of this going to print.

Care has been taken to anonymise the data using pseudonyms where required to ensure privacy of the informants. I have avoided disclosing any information that I consider harmful. I have done my best to report honestly the turn of events that have occurred through this journey, any oversight is my responsibility alone. 


\section{Findings}

The real intangible is the human element which, with the best will in the world, most of us cannot control to anywhere near the same degree that a product manager controls the formulation of a beauty soap, for example.

- Gary Knisley

This chapter presents an overview of the main findings of the papers I-V.

\subsection{Paper I}

The aim of this work was to explore how Service Design (SD) can support the transition to Person Centred Care (PCC). Building on the conceptual frameworks derived by McCormack and McCance (2006) and by Mead and Bower (2000), an integrative framework highlighting the dimensions of context, process, roles, and outcomes, to support the transition of healthcare service systems toward PCC was developed (see Figure 4.1). These are described as follows:

- Context: This dimension refers to both the context of care and the context where people experience illness and health. Personal meaning attributed to the illness and differing life circumstances can help contextualise individual experiences. The context in which care is delivered includes an appropriate skill mix, effective staff relationships, supportive and facilitative organisational systems, and the potential for innovation and risk taking. 
- Roles: This dimension refers to the shift in the patient's role as an expert of their own experience, from passive to more active, and potentially that of a critic. Here, a more egalitarian relationship between patients and medical personnel with redistribution of power is imagined.

- Process: This dimension highlights the importance of involving the patient in the decision-making process, understanding their values and beliefs to help them make sense of their situation and recognise what is important to them. It requires higher engagement from personnel and shared-decision making to elicit participation in the care process.

- Outcomes: This dimension refers to the shift from biological outcomes such as eradicating an illness towards supporting patients' wellbeing, satisfaction and increasing the involvement of patients and their caregivers.
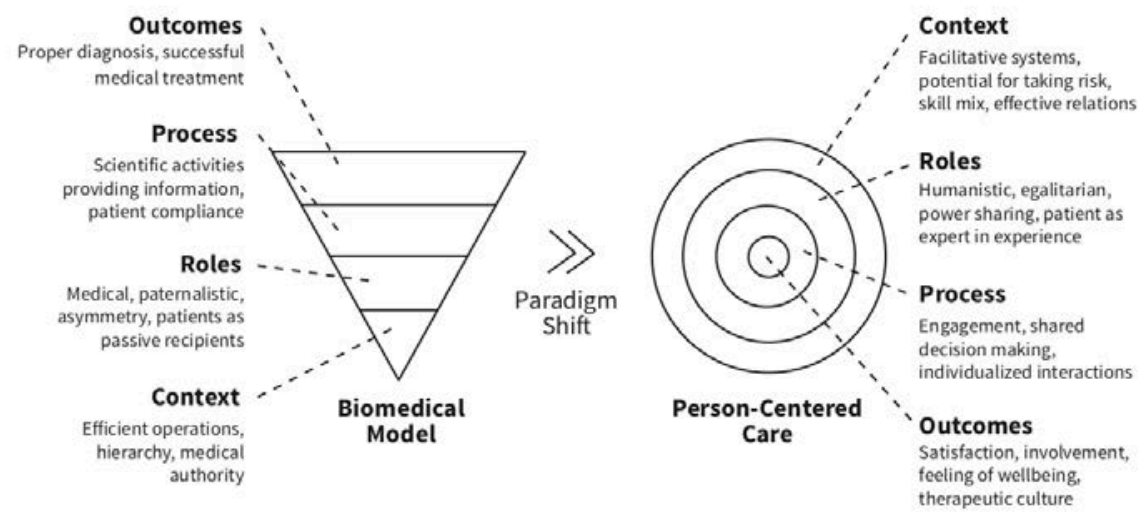

Figure 4.1: Framework highlighting transformational dimensions. Graphical representation reproduced with permission from Josina Vink. 
Findings

Table 4.1: Proposed SD methods to support the four dimensions of transformation

Dimensions of Context $\quad$ Roles
PCC

\begin{tabular}{|c|c|c|c|c|}
\hline $\begin{array}{l}\text { Alignment } \\
\text { between PCC } \\
\text { \& SD }\end{array}$ & $\begin{array}{l}\text { User expertise \& } \\
\text { holistic mindset }\end{array}$ & Shift in power & $\begin{array}{l}\text { Co-creation of } \\
\text { value }\end{array}$ & Focus on needs \\
\hline
\end{tabular}

\begin{tabular}{|c|c|c|c|c|}
\hline $\begin{array}{l}\text { Transition } \\
\text { Catalysed by } \\
\text { SD }\end{array}$ & $\begin{array}{l}\text { Institutional and } \\
\text { structural change } \\
\text { (Kurtmollaiev et } \\
\text { al., 2018; } \\
\text { Rodrigues \& Vink, } \\
\text { 2016) }\end{array}$ & $\begin{array}{l}\text { Role change } \\
\text { (Overkamp \& } \\
\text { Holmlid, 2017; } \\
\text { Peltonen, 2017) }\end{array}$ & $\begin{array}{l}\text { Change in habits } \\
\text { and routines } \\
\text { (Wetter-Edman, } \\
\text { Vink, \& } \\
\text { Blomkvist, 2017) }\end{array}$ & $\begin{array}{l}\text { Change } \\
\text { outcomes and } \\
\text { experience } \\
\text { (Trischler, } \\
\text { Pervan, Kelly, \& } \\
\text { Scott, 2018; } \\
\text { Zomerdijk \& } \\
\text { Voss, 2010) }\end{array}$ \\
\hline $\begin{array}{l}\text { Supportive } \\
\text { Methods } \\
\text { (examples) }\end{array}$ & $\begin{array}{l}\text { coaching, service } \\
\text { walkthroughs }\end{array}$ & $\begin{array}{l}\text { roleplay, } \\
\text { stakeholder } \\
\text { maps, co-design } \\
\text { sessions }\end{array}$ & $\begin{array}{l}\text { contextual } \\
\text { interviews, co- } \\
\text { design sessions }\end{array}$ & $\begin{array}{l}\text { co-design } \\
\text { sessions, service } \\
\text { blueprints }\end{array}$ \\
\hline
\end{tabular}

Facilitator

Design capability (Malmberg, 2017)

Based on this conceptual framework, we identified five key areas of alignment between SD and PCC as follows:

1. Expert of one's own care: The patient (i.e., the user) is viewed as expert on their own life and experiences.

2. Holistic mindset: There is a need for a holistic approach and mindset since a person's life is not limited to their interactions with healthcare.

3. Co-creation of value: Value is co-created between those involved in the service situation. 


\section{Chapter 4}

4. A shift in power: There is a need for a shift in power amongst the involved actors.

5. Focus on needs: Instead of focussing only on solutions, this focus shifts to needs.

The alignment between PCC and SD provides a foundation for why SD is an appropriate driver of the paradigm shift towards PCC. Table 4.1 summarizes this alignment, the associated transitions catalysed by $\mathrm{SD}$, examples of supportive service design methods, and the need for design capability to support such a transformation across these dimensions.

\subsection{Paper II}

A targeted literature search in Paper II reveals a fragmented understanding of the term resilience in service literature. We define service system resilience as the collective capacity for intentional action in responding to ongoing change, coordinated across scales in order to create value. Paper II analysed the generative design process utilising the trajectory of social-ecological transformations. The first and second phases - preparing for change and navigating the transition - essentially encourage development of network relationships, building knowledge and creating arenas for safe experimentation, while the third phase requires building resilience of the new state (Olsson, Folke, \& Hahn, 2004; Olsson et al., 2006). The results show that three meta phases - familiarising, experimenting and anchoring - correspond to the phases in the resilience thinking transformation framework and illustrate SD's role in navigating transformations. We identify 19 design practices (Table 4.2) undertaken during the design project and explicitly link these to resilience-enabling processes. The results highlight the invisible role of resilience, the importance of aligning perspectives and altering thinking guided by leadership, supported by arenas for experimentation, and the necessity of embedding design capability. The results imply that SD can be a driver not only for driving transformation but also enabling resilience. 
Table 4.2: Design practices identified during the project linked to resiliencebuilding processes.

\begin{tabular}{|c|c|c|}
\hline Design practice & Description & $\begin{array}{l}\text { Processes and strategies that } \\
\text { contribute to resilience } \\
\text { (adapted from Olsson et al. } \\
(2006))\end{array}$ \\
\hline $\begin{array}{l}\text { Acknowledging } \\
\text { participants' } \\
\text { experience }\end{array}$ & $\begin{array}{l}\text { Recognising participants' efforts } \\
\text { and experience throughout the } \\
\text { project. }\end{array}$ & \\
\hline $\begin{array}{l}\text { Aligning } \\
\text { perspectives }\end{array}$ & $\begin{array}{l}\text { Finding common ground and } \\
\text { matching expectations, } \\
\text { motivations and values amongst } \\
\text { actors to enable shared } \\
\text { understanding. }\end{array}$ & $\begin{array}{l}\text { - Identifying and clarifying } \\
\text { objectives } \\
\text { - Developing norms to avoid } \\
\text { loss of trust among actors } \\
\text { - Supporting diffusion of values } \\
\text { through social networks }\end{array}$ \\
\hline Altering thinking & $\begin{array}{l}\text { Changing actors' perceptions } \\
\text { and shifting perspectives by } \\
\text { identifying tensions and } \\
\text { confronting assumptions. }\end{array}$ & $\begin{array}{l}\text { - Fostering dialogue with actors } \\
\text { - Influencing decision makers at } \\
\text { higher levels } \\
\text { - Supporting diffusion of values } \\
\text { through social networks }\end{array}$ \\
\hline $\begin{array}{l}\text { Assessing } \\
\text { implementations }\end{array}$ & $\begin{array}{l}\text { Evaluating the small-scale tests } \\
\text { and eliciting feedback from } \\
\text { actors. }\end{array}$ & $\begin{array}{l}\text { - Developing, communicating } \\
\text { and building support } \\
\text { - Encouraging and supporting } \\
\text { actors to perform monitoring }\end{array}$ \\
\hline Bridging & $\begin{array}{l}\text { Scaffolding and creating } \\
\text { conceptual links between the } \\
\text { various activities, outputs and } \\
\text { stages. }\end{array}$ & $\begin{array}{l}\text { - Identifying and clarifying } \\
\text { objectives } \\
\text { - Making sense of and guiding } \\
\text { the management process }\end{array}$ \\
\hline Capturing needs & $\begin{array}{l}\text { Undertaking research activities } \\
\text { to foreground the user, } \\
\text { maintain empathy and generate } \\
\text { insights to ground further } \\
\text { development work. }\end{array}$ & $\begin{array}{l}\text { - Facilitating dialogue with } \\
\text { actors } \\
\text { - Developing personal ties }\end{array}$ \\
\hline Connecting actors & $\begin{array}{l}\text { Establishing comfort and trust, } \\
\text { building connections within } \\
\text { actor networks and finding } \\
\text { synergies to work } \\
\text { collaboratively. }\end{array}$ & $\begin{array}{l}\text { - Building trust in times of } \\
\text { stability to facilitate conflict } \\
\text { resolution } \\
\text { - Initiating and sustaining social } \\
\text { networks of key individuals } \\
\text { - Collaborating with } \\
\text { (inter)national actors }\end{array}$ \\
\hline
\end{tabular}




\begin{tabular}{|c|c|c|}
\hline Envisioning & $\begin{array}{l}\text { Imagining (desired) futures by } \\
\text { formulating visions and goals. }\end{array}$ & $\begin{array}{l}\text { - Envisioning the future } \\
\text { together with actors }\end{array}$ \\
\hline $\begin{array}{l}\text { Exploring } \\
\text { alternatives }\end{array}$ & $\begin{array}{l}\text { Revealing multiplicity and } \\
\text { complexity, perceiving and } \\
\text { examining other possibilities. }\end{array}$ & $\begin{array}{l}\text { - Envisioning the future } \\
\text { together with actors } \\
\text { - Encouraging and supporting } \\
\text { actors to manage system } \\
\text { processes }\end{array}$ \\
\hline $\begin{array}{l}\text { Facilitating } \\
\text { knowledge } \\
\text { exchange }\end{array}$ & $\begin{array}{l}\text { Leveraging actors (and their } \\
\text { networks) for their experience } \\
\text { and knowledge to identify and } \\
\text { address gaps, and enable } \\
\text { knowledge sharing. }\end{array}$ & $\begin{array}{l}\text { - Fostering dialogue with actors } \\
\text { - Synthesising and mobilising } \\
\text { knowledge for management } \\
\text { - Mobilising external knowledge } \\
\text { when needed }\end{array}$ \\
\hline Guiding actors & $\begin{array}{l}\text { Helping actors during the } \\
\text { process by giving them } \\
\text { direction, encouraging learning } \\
\text { and developing their skills by } \\
\text { doing. }\end{array}$ & $\begin{array}{l}\text { - Making sense of and guiding } \\
\text { the management process }\end{array}$ \\
\hline $\begin{array}{l}\text { Laying the } \\
\text { groundwork }\end{array}$ & $\begin{array}{l}\text { Creating a foundation by } \\
\text { positioning project work and } \\
\text { paving the way for collaborative } \\
\text { development. }\end{array}$ & $\begin{array}{l}\text { - Making sense of and guiding } \\
\text { the management process } \\
\text { - Providing coordination of } \\
\text { project and arenas for } \\
\text { collaboration }\end{array}$ \\
\hline $\begin{array}{l}\text { Nurturing } \\
\text { reflexivity }\end{array}$ & $\begin{array}{l}\text { Triggering reflection and } \\
\text { awareness of the opportunities } \\
\text { and barriers given the existing } \\
\text { norms, values and structures. }\end{array}$ & $\begin{array}{l}\text { - Developing norms to avoid } \\
\text { loss of trust among actors } \\
\text { - Initiating projects and } \\
\text { selecting problems that can be } \\
\text { turned into possibilities }\end{array}$ \\
\hline $\begin{array}{l}\text { Organising } \\
\text { information }\end{array}$ & $\begin{array}{l}\text { Structuring and summarising } \\
\text { information through the use of } \\
\text { design methods and tools such } \\
\text { as visualisations and templates. }\end{array}$ & $\begin{array}{l}\text { - Synthesising and mobilising } \\
\text { knowledge for management }\end{array}$ \\
\hline (Re)Framing & $\begin{array}{l}\text { Formulating problem areas, and } \\
\text { challenges by adopting different } \\
\text { viewpoints. }\end{array}$ & $\begin{array}{l}\text { - Envisioning the future } \\
\text { together with actors }\end{array}$ \\
\hline $\begin{array}{l}\text { Reorganising } \\
\text { resources }\end{array}$ & $\begin{array}{l}\text { Distributing functions and roles } \\
\text { when testing new } \\
\text { configurations. }\end{array}$ & $\begin{array}{l}\text { - Encouraging and supporting } \\
\text { actors to manage system } \\
\text { processes }\end{array}$ \\
\hline Spurring action & $\begin{array}{l}\text { Stimulating actors by sparking } \\
\text { curiosity and creating a space } \\
\text { for exploration. }\end{array}$ & $\begin{array}{l}\text { - Providing arenas for trust } \\
\text { building among actors }\end{array}$ \\
\hline
\end{tabular}




\begin{tabular}{|l|l|l|}
\hline & & $\begin{array}{l}\text { - Encouraging and inspiring } \\
\text { actors to voluntary participation }\end{array}$ \\
\hline $\begin{array}{l}\text { Supporting new } \\
\text { structures }\end{array}$ & $\begin{array}{l}\text { Making changes to existing } \\
\text { structures to bolster } \\
\text { implemented alternatives. }\end{array}$ & $\begin{array}{l}\text { - Developing, communicating } \\
\text { and building support } \\
\text { - Encouraging and supporting } \\
\text { actors to manage system } \\
\text { processes } \\
\text { - Encouraging and supporting } \\
\text { actors to perform monitoring }\end{array}$ \\
\hline $\begin{array}{l}\text { Testing new } \\
\text { configurations }\end{array}$ & $\begin{array}{l}\text { Trying out alternatives on a } \\
\text { small-scale. }\end{array}$ & $\begin{array}{l}\text { - Encouraging and supporting } \\
\text { actors to manage system } \\
\text { processes } \\
\text { - Encouraging and supporting } \\
\text { actors to perform monitoring }\end{array}$ \\
\hline
\end{tabular}

\subsection{Paper III}

Paper III reports the results of an interview study analysed using critical incident technique (Flanagan, 1954) supported by design-driven generative tools (Sanders, 2000). We identify eight patterns of disruption: request, query, hiccup, delay, mistake, flaw, breakdown and the unexpected. The paper also contributes a disruption ripple model, and identifies five tensions in responding to disruptions: competing priorities, dealing with difficult others, mismatching expectations, shouldering responsibility and reluctant assistance. The ripple model and identified tensions illustrate the underlying complexities in network relationships.

Figure 4.2 shows a visual representation of the disruption ripple model, wherein depending on the disruption, it could be resolved at the nucleus of the service interaction or requires the activation of the focal actors' network(s). Each wave represents a degree of temporal activation of one or more network actors. As visualised in Figure 4.2, the data suggests that the type of disruptions necessitate a minimum level of network activation. For instance, a mistake is most likely to require at least one degree of activation. 


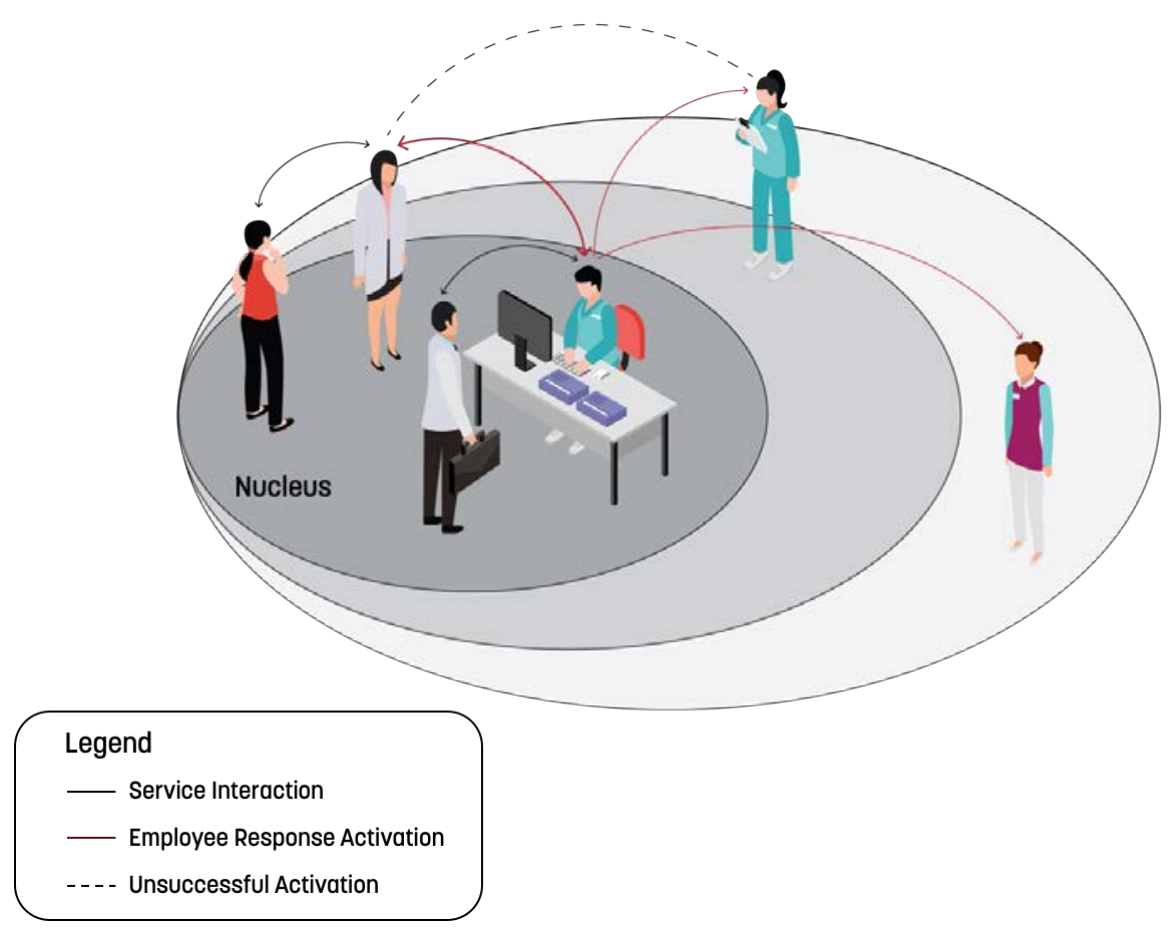

Figure 4.2: Visualisation of the ripple effect from a respondent's narrative

This study provides a more nuanced understanding of the disruptions emerging from an organisational network perspective. In doing so, it highlights the role and importance of relationships and tensions among service personnel. The findings indicate that despite tensions, leadership and a strong user focus can influence actors' responses. This has implications for the tensility of relationships (Akgün et al., 2016) as actors can be persuaded to maintain tenuous relations for the greater good. Further, maintaining relationships can also impact the resilience of the service providing network. In case of conflicting goals and roles, balanced centricity in supporting different actors in reaching their goals becomes vital (Gummesson, 2008). Conflicts can impact the tensility and connectivity (Akgün et al., 2016) of network relationships and affect their perceived possibilities for action (Rodrigues, Blomkvist, \& Holmlid, 2018) and improvisation (Pina e Cunha, Rego, \& Kamoche, 2009). This highlights the situated nature of improvisation and adaptation across different networks. 
From a managerial point of view, it is vital to understand the nature and origin of the disruptions in order to identify actors and resources in the network that can contribute to resolution, to gain clarity on which aspects can be spontaneously managed or not and what subsequent corrective measures can be taken. It shows that although front-line employees are important while responding to disruptive service encounters, network actors can significantly impact the possibilities for action and the quality of their (collective) response.

\subsection{Paper IV}

Paper IV paper investigates how the use of a service prototyping technique - desktop walkthrough (Blomkvist et al., 2016) enables participants to explore the variations inherent in services. Desktop walkthrough has been described as "a collaboratively constructed miniature of a service, and of which a set of artefacts (e.g. LEGO®) is used in the construction" (Blomkvist et al., 2016, p. 154). The video data are analysed using qualitative content analysis and the articulated variations are abstracted as categories. The resulting categories are then mapped across the service logic framework and the corresponding provider, joint and patient spheres (Figure 4.3).

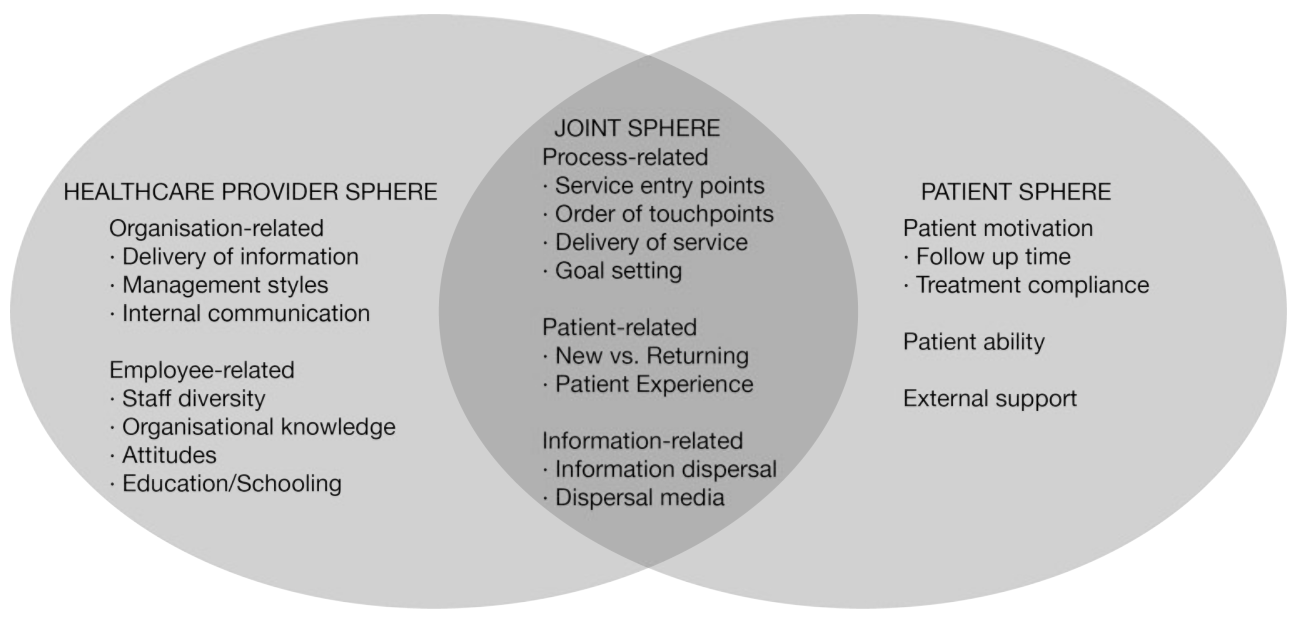

Figure 4.3: Variations mapped onto the Service Logic Framework 


\section{Chapter 4}

The results of this study concur Blomkvist and colleagues' (2016) findings that the desktop walkthrough technique supports inferential reasoning, facilitates re-representation and serves as shareable objects of thought. However, the prototypes not only helped the teams articulate insights but also allowed them to address the variations inherent in the service both explicitly and implicitly. Participants were able to engage in dialogue and reframe parts of or whole service journeys based on the variations they came across. Prototyping the service facilitated partial expression four types of variability - arrival, capability, effort and subjective preference (Frei, 2006). Paper IV clarifies how prototyping a service allows people untrained in design to diagnose variations that may occur in a future service and the decision-making process in accommodating variation. It provides a sense of the actions that need to be undertaken by the healthcare providers to:

- Facilitate value creation for the patients by creating the right preconditions in their organisational processes and by building shared understanding among the employees.

- Co-create value by positively engaging with the patients during the joint activities such as consultations, treatments and support groups.

- Gain an understanding of the activities in the patient sphere to influence and facilitate value creation outside the joint sphere.

\subsection{Paper V}

Paper V introduces strong concepts from the field of interaction design, as a form of generative, intermediate-level knowledge (Höök \& Löwgren, 2012) and its transferability to Design for Service (Wetter-Edman et al., 2014). The examples illustrate situations where one or more employees find themselves in a situation outside of the normal everyday routine. In these situations, each person has their own perception of the potential actions and associated resources available to them and possibly others involved in the situation. Accordingly, Perceived Action Potential (PAP) is defined as 
the subjective interpretation of an individual's (own) scope of action. The design elements valuable in other situations include:

- Improvised employee actions

- Resources that enable those actions

- Mandate for improvisation and adaptations

The concept of PAP would be valuable in other design situations to frame the nature and scope of the resources that actors can draw on during service in order to carry out the service to its fulfilment in a meaningful way. It underscores the contextual factors i.e. norms, resources, processes and relationships that an actor orients to thereby affecting PAP. It points to the interdependencies between the configuration of resources in a service system and schemas that shape actors during resource integration and value co-creation (Edvardsson \& Tronvoll, 2013). In order to explore these interdependencies and how they might affect the service experience, designers can look toward applying a sandbox approach when prototyping services. This would entail giving participating actors the freedom of action without a stringent linear storyline in order to meet a certain service goal. We suggest that Perceived Action Potential could be viewed as a strong concept, precisely because it is an aspect of a suggested future situation of service, is generative in the sense that it provides design possibilities and expresses intermediate knowledge. 



\section{Discussion}

When the cathedrals you build are invisible, made of perspectives and ideas, you forget you are inside them and that the ideas they consist of were, in fact, made, constructed by people who analyzed and argued and shifted our assumptions. They are the fruit of labor.

—Rebecca Solnit

This chapter discusses the main contributions and limitations of this work. It contextualises the findings from the individual papers in relation to the overall research aims.

\subsection{Extending the understanding of resilience in service}

Resilience has been discussed across several disciplines, yet its definition and ways to achieve it remain ambiguous (Taysom \& Crilly, 2017). Holling (1973) defines the concept of resilience as the persistence of relationships in systems and the ability of a system to absorb change and disturbance. This gave rise to an almost dichotomous perspective of resilience with one view favouring the efficiency, predictability and constancy of function (i.e., engineering resilience) and the other focusing on maintaining function (i.e., ecological resilience) (Holling, 1996). The concept of resilience has found application in a variety of fields, such as engineering, human resource management (Lengnick-Hall et al., 2011), child welfare (Skovdal \& Andreouli, 2011), supply chain management (Christopher \& Peck, 2004), disaster management (Bruneau et al., 2003) as well as individual (Luthar et al., 2000) and organizational psychology (Barnett \& Pratt, 2000). An 


\section{Chapter 5}

extensive literature review on resilience by Bhamra and colleagues (2011) reveals the multi-faceted and multi-disciplinary nature of resilience, with diversity in definitions stemming from the differences in perspectives and context. Most definitions are altered to align with the domain, wherein the purpose or identity of the system could affect which resilience characteristics are emphasised (Taysom \& Crilly, 2017).

A targeted literature review of the resilience concept in service journals revealed a paucity of understanding at the system level, with most work focused on resilience at the individual level. The purpose of service systems is value co-creation among system actors on different levels (Akaka et al., 2012; Vargo \& Akaka, 2012) that depend crucially on sharing capabilities and resources (Akaka, Vargo, \& Lusch, 2012; Maglio et al., 2015). Based on these differentiating characteristics, I argue that a better understanding of resilience in the context of service systems is needed. Accordingly, Paper II defines service system resilience as the collective capacity for intentional action in responding to ongoing change, coordinated across scales in order to create value. In doing so, it encompasses an alternative set of assumptions about systemic resilience, different from extant literature. The shift to alternative assumptions is described in detail in the following section.

\subsection{Shifting the assumptions of resilience in service}

In section 2.1.2, I problematised the conceptual understanding of resilience in service. The issues highlighted result mainly from adopting the ecological or engineering resilience perspectives discussed in the previous section. One explanation for this could be that early service development models (discussed in section 2.2.1) were derived from product development, where planning and control is important (Scheuing \& Johnson, 1989). Recently, some resilience scholars have advocated for what is defined as evolutionary resilience or social-ecological resilience (Davoudi et al., 2012; Walker, Holling, Carpenter, \& Kinzig, 2004; Walker, Salt, \& Reid, 2006). In this view, resilience is "the capacity of a system to absorb disturbance and reorganize while undergoing change so as to still retain essentially the same 
function, structure, identity, and feedbacks" (Walker et al., 2004, p. 5). Evolutionary resilience incorporates the dynamic interplay of persistence, adaptability and transformability (Folke et al., 2010; Walker et al., 2004), bringing the role of social capital, social learning, institutions and leadership within its scope (Olsson et al., 2006). Adaptability is defined as "the capacity of actors in the system to influence resilience (in a Social-Ecological System (SES) ${ }^{8}$, essentially to manage it)" (Walker et al., 2004, p. 4). SES here refers to, for example, wetlands, forests and other such landscapes managed by human actors. Scholars promoting this view acknowledge that while human actions influence resilience, intentionally or unintentionally, it is their intentional collective capacity that determines their response to changes (Folke et al., 2010). This is crucial since SESs are pre-dominantly managed by human actors. Transformability is defined as "the capacity to create a fundamentally new system when ecological, economic, or social structures make the existing system untenable" (Walker et al., 2004, p. 4).

Underpinning evolutionary resilience, is the notion of panarchy (Allen, Angeler, Garmestani, Gunderson, \& Holling, 2014; Holling \& Gunderson, 2002) understood as an interacting hierarchy of adaptive cycles. It suggests that systems cannot be viewed from a single scale or cycle. Instead, it posits that there are multiple nested cycles interacting at different scales. They interact at multiple scales from large to small, at varying speeds from slow to fast and across timeframes ranging from long to short. Additionally, the phases within these cycles are not fixed, do not occur sequentially and may be connected at several levels by feedback loops. It is this evolutionary perspective that my thesis turns to, to look for alternative assumptions to shape theory (Gustafsson et al., 2016). The articulation of these alternative assumptions does not intend to establish a final truth, rather it creates opportunities for understanding (Alvesson \& Sandberg, 2011).

${ }^{8}$ Abbreviation used in original. 


\section{Chapter 5}

\subsubsection{From Individual to Collective}

The definition of service system resilience provided in this thesis shifts the focus from the micro individual perspective to coordinated, collective capacity for action at multiple levels. In highlighting coordinated, collective capacity, this research shifts the onus of system resilience to multiple actors and their interactions. Extant research emphasises networked service systems (Spohrer, Piciocchi, \& Bassano, 2012) and the importance of collaboration in creating value in such networks (Akaka et al., 2012; Mele \& Polese, 2011). However, the results from Paper III show that despite aspiring to create value for users, collaboration between actors can be hampered by underlying tensions. This is an important finding for understanding the connectivity and tensility of connections (Akgün et al., 2016), relational intensity (Manzini, 2015) and the synergistic drivers of multi-actor interaction (Mele \& Polese, 2011). Connectivity denotes the level of openness to new ideas, possibilities for action, and creativity in the connections among people. Tensility denotes "the extent to which the connection among people can survive in different circumstances, facing tensions, conflict, stress, challenges, and problems" (Akgün et al., 2016, p. 106). Tensility serves as an indicator of resilience in the connections among people and groups (Akgün \& Keskin, 2014), strengthening support for the emphasis on the collective aspect for system resilience. Relational intensity refers to the nature of relationships ranging from formalised interactions to putting oneself on the line at a personal level (Manzini, 2015). While recognising the importance of individual resilience in coping with disruptions in service interactions (e.g., successful service recovery (Azab et al., 2018)), this definition emphasises that a service system's resilience is contingent on coordinated, collective action. Underpinning this is the role of networks and the importance of relationship configurations that enable actors to access, adapt, and integrate resources to create value (Akaka et al., 2012). By specifying that action is required at multiple levels, it leaves no ambiguity about the multi-scalar nature of systemic resilience. 
This resilience conceptualisation also reflects the degree to which actors are capable of self-organising (Folke, Colding, \& Berkes, 2002). For example, Paper III points out how poor coordination can negatively affect how actors respond to a situation, thereby impacting resilience. Such coordinated, collective action also has implications for multi-level governance (i.e., shared system of rules) (Spohrer et al., 2012). Paper II shows how national-level policy created a window of opportunity (Olsson et al., 2006) for regional actors to come together and address the transition towards Person Centred Care (PCC). This suggests that institutionalised rules can enforce or delegitimise visions of preferred futures. Participation becomes a pre-requisite for collective action (Biggs et al., 2012). It also highlights the importance of aligning perspectives of participating actors to help achieve this transition. Working in silos and difficulty in collaborating across organisations was brought up by several participants. One way of addressing this is the consideration of polycentric governance with multiple governing authorities at different scales (Biggs et al., 2012). This is similar to what has been described as networked governance (Bason, 2013) in design for social innovation. Networked governance is "the interconnectedness of independent units of authority and power, whether individual, community, state or corporate. Networked governance moves from vertical to horizontal approaches to decision-making and is characterised by systems of communications, knowledge, exchange and dialogue" (Manzini, 2015, p. 159). Another way, as discussed in Institutional Theory, is the concept of proto-institutions as precursors to institutions emerging from collaboration through a small set of actors, who negotiate competing and collaborative interests (Vink et al., 2019). A shift to collective action also implies moving to more distributed forms of governance. This means that Service Design must incorporate multi-level forms of governance and adaptive co-management (Olsson, Folke, \& Berkes, 2004) into service systems to enable resilience, not just focus on nurturing the competencies of individuals and organisations. 


\subsubsection{From Intrinsic Property to Intentional Capability}

The service literature search reveals that resilience is mostly conceptualised at the micro-individual level as an individual trait or intrinsic ability that changes over time (Barnes et al., 2014; Loomba, 2017; Shneikat \& Ryan, 2017). Systemic conceptualisations of resilience often describe it as a property ${ }^{9}$ or quality that a system possesses (Baron et al., 2005; Borchert \& Mattoo, 2010; Navarro-Espigares et al., 2012). One explanation could be that resilience in these conceptualisations are defined in terms of characteristics that are relevant for that particular field (Taysom \& Crilly, 2017). Human actors may not necessarily be characteristic or relevant to understanding resilience in these contexts. For example, resilience in the context of software systems is discussed in terms of the algorithm's reactions to injecting faults in the system (Sharma, Haran, Rakamaric, \& Gopalakrishnan, 2013). The focus on resilience as a property may also be a reflection of the ways in which the ecosystem metaphor obscures the intentionality and agency of actors evident in service systems (Mars et al., 2012). However, service systems are characterised by primarily human actors and their shared capabilities and resources (Maglio et al., 2015; Mele \& Polese, 2011). While most service system behaviour is emergent, system actors can at least partly design policies and interventions that influence this behaviour and evolution (Fiksel, 2003). This is to some extent evident in Paper II, where the guidelines were created to explicitly incorporate patientcentred care in healthcare systems. The emphasis on intentional in the offered definition therefore dictates that systemic resilience requires deliberate action from participating actors. Paper II also points out how some teams lapsed into passivity when working without a leadership figure. Such inaction, particularly in the absence of leadership, can negatively impact resilience. In the CE2 case, teams actively decided on alternative measures to be undertaken to support their patients. Paper III shows how

\footnotetext{
${ }^{9}$ For example, liquidity is a property of water.
} 
actors may overcome tensions in order to better serve their users, indicating deliberate action towards creating value for users. System resilience definitions specify retaining "essentially the same function, structure, identity, and feedbacks" (Walker et al., 2004). In service systems, actors shape the structures through direct interaction, which in turn shape their actions (Giddens, 1984; Vargo \& Lusch, 2016). This is also reflected in actors' perceived action potential (Paper V). When going through changes, actors may experience conflicting structures and identities, and evolving functions and feedbacks (Rodrigues \& Vink, 2016). Acknowledging this dialogical process between human activity and the structures within which it occurs, this definition does not specify retaining the same functions, structure, identity and feedbacks as an indicator of resilience. Thus, service system resilience is not a property that is intrinsic to the system but relies on human actors to coordinate, collaborate and manage it through the shaping of structures. This requires an understanding of the configurations of relationships and nurturing intentionality through reflexivity.

\subsubsection{From Bouncing to Ongoing}

As stated in section 2.1.2, the extant views on resilience emphasise bouncing back (or forward) to an (new) equilibrium state. This frames the meaning of resilience as "a buffer for conserving what you have and recovering to what you were" (Folke et al., 2010, p. 20). This suggests a return to an earlier normality without questioning what this normality entails and that it might not necessarily be desirable nor possible (Nilsson \& Jahnke, 2018; Pendall, Foster, \& Cowell, 2010). Much of resilience-building literature focuses on responses to crises or large turbulent events while overlooking the impact of small, gradual and cumulative changes (Davoudi et al., 2012). While bouncing forward suggests movement in new directions, it still assumes an equilibrium state of stability in the new state. The definition proposed in the thesis puts forth the alternative assumption in responding to ongoing change. In doing so, it opens the possibility for addressing small, gradual changes, large-scale disturbances, everyday disruptions and opportunities, 


\section{Chapter 5}

embracing change as a requisite to persist (Folke et al., 2010). It emphasises the ability of systems to succeed under varying conditions (Hollnagel, 2014) or creating the conditions to succeed (Legeby et al., 2018). The former is considered as an interactive way of coping with changes related to adaptability. Paper III, Paper IV and Paper V show how actors might respond to everyday variability and minor to large disruptions. The latter is considered as a proactive shaping linked with transformability. Paper II shows how transitioning happens in a continuous way. Further, this aligns with the view that designing for service remains incomplete (Kimbell, 2011). This suggests that Service Design needs to endure in an ongoing way in service systems over the long term, in order to enable resilience.

\subsection{Enabling resilience through design}

Utilising an evolutionary resilience lens allows for distinguishing between types of responses to change such as adaptation and transformation (Folke et al., 2010; Olsson et al., 2006; Walker et al., 2004). A key aspect of this distinction is specified resilience or general resilience. In practice, actors may need to respond to problems arising from a specific set of sources or shocks requiring adaptation. This is referred to as specified resilience. Specified resilience arises in response to the question "resilience of what, to what?" (Carpenter, Walker, Anderies, \& Abel, 2001). For example, in a service context, hotel employees may need to improvise a solution if a guest's booking has not been captured in the booking management system. Such adaptive capacity captures the learning aspect of system behavior (Carpenter et al., 2001). In other instances, actors may be concerned with resilience to all kinds of changes, disruptions and shocks, including novel ones requiring transformation. This is referred to as general resilience. General resilience is about managing uncertainty in all ways and is underspecified. This distinction is important because traditionally, the focus has been on specified resilience (Anasori et al., 2019; Barnes et al., 2014), which likely narrows the options for dealing with novel disruptions and shocks (Folke et al., 2010). Recognising that only fostering specified 
resilience is not sufficient to sustain service systems over the long term is the stepping stone to understanding the need for transformational change. The following sections discuss the contribution of individual papers in highlighting where and how Service Design might enable resilience in services through transformative and adaptive perspectives.

\subsubsection{Transforming}

In resilience thinking, transformability is defined as "the capacity to create a fundamentally new system when ecological, economic, or social structures make the existing system untenable" (Walker et al., 2004, p. 4). Transformational change can be a deliberate process, introduced by those involved or it can be forced as a result of changing socio-economic or environmental changes. Resilience scholars acknowledge that transformational change is accompanied by "shifts in perception and meaning, social network configurations, patterns of interactions among actors including leadership and political and power relations, and associated organisational and institutional arrangements" (Folke et al., 2010).

\section{The value of experimentation}

In transitioning toward Person Centred Care, Paper I highlights four key dimensions where Service Design can affect transformational change context, roles, process and outcomes. Paper I suggests that Service Design can catalyse change in institutions and structures (Kurtmollaiev et al., 2018; Rodrigues \& Vink, 2016), shifts in roles (Overkamp \& Holmlid, 2017; Peltonen, 2017), habits and routines (Wetter-Edman et al., 2017) and changes in outcomes and experience (Trischler et al., 2018; Zomerdijk \& Voss, 2010) and recommends supportive design and prototyping methods that can enable these interventions. Prototyping through its embodiment of alternatives has been shown to reshape mental models at micro-level stimulating change at the macro-institutional level (Vink et al., 2018). Thus, transformative change entails a zooming in and zooming out across the levels (Vink et al., 2018). Such zooming in and out would also support the 


\section{Chapter 5}

identification and understanding of what is required at different levels to enable resilience. Its holistic perspective (Fayard et al., 2017; Stickdorn et al., 2011) also encourages systems sight (Rye, 2018), which denotes building a sense of the system's structure, patterns, relationships, experiences and possibilities. Service Design encompasses iterative and experimental practices of exploring possibilities through prototyping, encouraging trial and error (Karpen et al., 2017). Service Design scholars frame prototypes as surrogate situations which occur in a liminal state (Blomkvist, 2014). Surrogate here refers to an alternative constructed situation when what is to be investigated or understood is not accessible or present. Liminal state emphasises a space where the temporal constraints of the real world are relaxed, and experimenting and testing can occur within the surrogate situation. This indicates that Service Design has the potential for establishing safe areas for exploration and experimentation.

\section{The significance of participation}

Transformations require active participation (Sangiorgi, 2010). Service Design is participatory in nature and opens up for multiple actors to collaborate and share their ideas through a co-design process (Holmlid, 2009; Trischler et al., 2018). Co-design is a participatory approach used in Service Design. In a broader sense it refers to "the creativity of designers and people not trained in design working together in the design development process" (Sanders \& Stappers, 2008, p. 6). Degrees of participation range from involving users in exploration or testing to cooperative partners engaged in making decisions (Bossen, Dindler, \& Iversen, 2010; Halskov \& Hansen, 2015). Paper II and Paper IV report on how involving users and other stakeholders can lead to designing services that better support preferable value outcomes. Participatory design practices reportedly result in better cooperation among actors, better relations, improved innovation practices, processes and capabilities, better decision-making, mutual learning and continuous improvements (Halskov \& Hansen, 2015; Steen, Manschot, \& De Koning, 2011). Taking into 
account a wide range of perspectives is an attribute of resilient decisionmaking (Legaspi, Maruyama, Nararatwong, \& Okada, 2014). This indicates that Service Design is well-positioned to facilitate coordinated, collective action required to enable resilience.

\section{The importance of embedding design}

Paper II identifies familiarising, experimenting and anchoring as the broader roles of Service Design in navigating transformational change. It explicitly links factors and processes contributing to resilience with the different design practices. Underscoring Paper I and Paper II is the need for organisations to build design capability - an ability to utilise the Service Design approach and associated methods and tools (Malmberg, 2017). If an organisation or system is aiming for transformational changes it needs to understand how design methods work, as well as how and why these methods and skills are utilised (Lin, 2014). This is vital for realising changes and ensuring that the transition can happen in an ongoing way. Another aspect is the access of design competence - through a (design) consultancy, hiring in-house service designers or training existing personnel (Blomkvist, 2015; Malmberg, 2017). This can impact Service Design contributions to enhancing resilience, since a temporary form of acquisition may not be able to support and institutionalise transformational change. Service Design needs to be part of an organisation's development portfolio (Malmberg \& Wetter-Edman, 2016). This often implies a culture and structures that enable the incorporation of Service Design (Malmberg, 2017). However, organisational resistance when practicing Service Design (Kurtmollaiev et al., 2018), its design readiness and lack of common vocabulary (Bailey, 2012) can hamper these efforts. Nevertheless, such an embedded design capability is necessary for enabling resilience due to the ongoing nature of change. 


\section{Chapter 5}

\subsubsection{Adapting}

Adaptation requires adjusting responses to external drivers and internal processes and allowing for development within the current state (Folke et al., 2010). Here, adaptability is understood as indicative of resilience when responding to problems or disruptions arising from a specific set of sources or shocks. Services are typically characterised by heterogeneity (Zeithaml et al., 1985). This heterogeneity can also be a source of variability that can result in variations or disruptions. New Service Development (NSD) literature suggests one way to handle this is the reduction of variety through standardisation (de Brentani, 1989). However, standardisation of human actions is nearly impossible, with customers being suggested at a major source of variability (Moeller, 2010). Resilience literature suggests that managing variability requires definition of an envelope of potential variability (Cuvelier \& Falzon, 2010). Potential variability encompasses an area of situations considered a priori as likely to occur. This is complemented by an area of unthought-of variability that is not foreseen. However, this classification is acknowledged as subjective since it relies on categorisation of situations experienced by the actors (Cuvelier \& Falzon, 2010).

Paper III identifies a typology of disruptions that can occur in service situations. Paper IV shows how the desktop walkthrough service prototyping technique (Blomkvist et al., 2016) facilitates participants discovery and exploration of variations in their interactions and service processes. This typology of disruptions and categories of variation can be used as generative constructs (Sanders \& Stappers, 2012) to provide a richer basis for exploration in the early phases of the design process. Within service literature, they can inform the development and testing of alternative service recovery strategies. Previous Service Design research has also explored the use of mistakes, delays and failures as part of service walkthroughs (Blomkvist \& Bode, 2012). The typology presented in Paper III further extends this understanding of deviations. They can be considered as tools to pushing the envelope of potential variability in service 
situations, allowing focal actors to better adapt to emerging situations and institutionalising responses to certain types of variations and disruptions. While Paper IV focusses on one prototyping technique for exploring variation, other Service Design tools and methods can help in uncovering variability. For example, Halvorsrud et al. (2016) identified four types of deviations when analysing customer journeys in contrast to the ideal customer journey. They are: the occurrence of ad hoc touchpoints, irregularities in the sequence of logically connected touchpoints, occurrence of failures in touchpoints, and missing touchpoints. Paper $\mathrm{V}$ identifies Perceived Action Potential (PAP) as a strong concept through the use of illustrative examples. PAP refers to the possibilities of what an actor thinks they can do. For example, one of the possibilities can be improvisation (Pina e Cunha et al., 2009), which captures creativity, spontaneity, and bricolage (i.e., the ability to assemble new services from available resources) (Secchi, Roth, \& Verma, 2016). While the concept of PAP is in its nascent stages, recent research suggests that inclusive Service Design needs to assume a certain variability in the user population as well as in the PAPs of service providing actors (Huan, Arvola, \& Holmlid, 2020). Service Design with its experimental, participatory approach can enable exploration of variability. Table 5.1 provides an overview of how the individual papers have contributed to an understanding of responding to transformative as well as adaptive change. 
Chapter 5

Table 5.1: Overview of individual paper contributions to the thesis

\begin{tabular}{|c|c|c|c|c|c|}
\hline \multirow[t]{2}{*}{ Paper Title } & \multicolumn{5}{|c|}{ Contribution to thesis } \\
\hline & $\begin{array}{l}\text { Transform- } \\
\text { ability }\end{array}$ & $\begin{array}{l}\text { Adapt- } \\
\text { ability }\end{array}$ & $\begin{array}{l}\text { Micro- } \\
\text { individual }\end{array}$ & $\begin{array}{l}\text { Meso- } \\
\text { Organisational }\end{array}$ & $\begin{array}{l}\text { Macro- } \\
\text { System }\end{array}$ \\
\hline $\begin{array}{l}\text { Paper I: Service } \\
\text { Design as a } \\
\text { Transformational } \\
\text { Driver Toward } \\
\text { Person-Centered } \\
\text { Care in } \\
\text { Healthcare }\end{array}$ & $\checkmark$ & & $\checkmark$ & $\checkmark$ & $\checkmark$ \\
\hline $\begin{array}{l}\text { Paper II: } \\
\text { Leveraging service } \\
\text { design to enhance } \\
\text { resilience in } \\
\text { services }\end{array}$ & $\checkmark$ & & $\checkmark$ & $\checkmark$ & $\checkmark$ \\
\hline $\begin{array}{l}\text { Paper III: Patterns } \\
\text { of disruption: } \\
\text { diagnosing } \\
\text { response } \\
\text { mechanisms in } \\
\text { actor networks }\end{array}$ & & $\checkmark$ & $\checkmark$ & $\checkmark$ & \\
\hline $\begin{array}{l}\text { Paper IV: } \\
\text { Discovering } \\
\text { Service Variations } \\
\text { through Service } \\
\text { Prototyping }\end{array}$ & & $\checkmark$ & $\checkmark$ & $\checkmark$ & \\
\hline $\begin{array}{l}\text { Paper V: } \\
\text { Perceived Action } \\
\text { Potential: A strong } \\
\text { concept in } \\
\text { development }\end{array}$ & & $\checkmark$ & $\checkmark$ & & \\
\hline
\end{tabular}




\subsection{Summarising Designing for Resilience}

Normative process models in NSD orient towards planning, management, and monitoring, assuming that design outcomes in the process can be specified and controlled, and that this control is important (Holmlid et al., 2017). This is problematic particularly in real-world instances where things are often prone to not going as planned. In such instances, the inclusive, contextual, holistic and emergent nature of service design (Karpen et al., 2017) can offer valuable insights to guide service interactions and realise resilience in services. The NSD perspective, with its roots in New Product Development (NPD) (Scheuing \& Johnson, 1989) and the focus on variation reduction (Pina e Cunha et al., 2009), is more aligned with the resilience view of robustness or withstanding change (Janssen, Anderies, \& Ostrom, 2007). Given this focus, service literature has often emphasised service recovery as a strategy in response to failures and service disruptions (Bell \& Zemke, 1987; Chou, Hsu, \& Goo, 2009; Van Vaerenbergh \& Orsingher, 2016). Methods such as Critical Incident Technique (Flanagan, 1954) were used to analyse reactions in service encounters in hindsight (Bitner et al., 1990). One explanation for this could be that at the time, service research was just starting to come into its own.

In this thesis, I propose the 'designing for service' view of Service Design as a way to address the adaptability and transformability aspects of evolutionary resilience for service systems. Underpinning this view is the understanding that services can never be fully planned and that designing for service is never complete (Garud et al., 2008; Kimbell, 2011). Adaptability emphasises improvisation (Cunha, Cunha, \& Kamoche, 1999; Pina e Cunha et al., 2009) and coping strategies to succeed in varying conditions. Here, adaptation is understood as interactive and emergent in response to the situation. The exploration of variability in design is informed by insight as shown in Paper IV. In contrast, transformability emphasises creating the conditions to succeed. This implies a proactive approach toward shaping alternative futures. Here, the design principles of 


\section{Chapter 5}

envisioning and foresight along with experimentation (Karpen et al., 2017) can help create and shape futures. Table 5.2 provides an overview of these perspectives synthesised based on the theory and analysis of empirical data. This framing helps answer calls for further explanation of how the principles of emergence, participation and interdependence play out when designing for complex service systems (Sangiorgi et al., 2017) by clarifying how design practitioners can engage with different types of change (see Figure 5.1).

Table 5.2: Synthesis of resilience characteristics and service development views

\begin{tabular}{|c|c|c|c|c|c|}
\hline $\begin{array}{l}\text { Resilience } \\
\text { characteris- } \\
\text { tics }\end{array}$ & $\begin{array}{l}\text { Development } \\
\text { perspective }\end{array}$ & $\begin{array}{l}\text { Emphasis } \\
\text { on }\end{array}$ & $\begin{array}{l}\text { Response } \\
\text { actions }\end{array}$ & $\begin{array}{l}\text { Strategic } \\
\text { focus }\end{array}$ & $\begin{array}{l}\text { Informed } \\
\text { by }\end{array}$ \\
\hline Robustness & $\begin{array}{l}\text { New Service } \\
\text { Development }\end{array}$ & $\begin{array}{l}\text { Planning \& } \\
\text { control }\end{array}$ & Reactive & Recovering & Hindsight \\
\hline Adaptability & $\begin{array}{l}\text { Designing for } \\
\text { Service }\end{array}$ & $\begin{array}{l}\text { Succeeding } \\
\text { in varying } \\
\text { conditions }\end{array}$ & Interactive & $\begin{array}{l}\text { Improvising/ } \\
\text { Coping }\end{array}$ & Insight \\
\hline $\begin{array}{l}\text { Transform- } \\
\text { ability }\end{array}$ & $\begin{array}{l}\text { Designing for } \\
\text { Service }\end{array}$ & $\begin{array}{l}\text { Creating } \\
\text { conditions } \\
\text { to succeed }\end{array}$ & Proactive & Shaping & Foresight \\
\hline
\end{tabular}

I define service system resilience as the collective capacity for intentional action in responding to ongoing change, coordinated across scales in order to create value. The stress on coordinated, collective capacity for action highlights the importance of designing for network relationships. This is also consistent with prior research on design for social innovation, where scholars have highlighted the dependence of community resilience on, but not limited to, their social relationships and relational structure (Baek et al., 2015). Previous 
research has explored the design of relationships through a sensory, material tool to create a shared relational vocabulary (Aguirre-Ulloa \& Paulsen, 2017). Such a material, relational language can be used to explore the relational shifts, reciprocity and power dimensions in relationships and how they might affect the capacity for action. In framing implementation as transforming service, Overkamp (2019) highlights that such transformational efforts enable enactment of roles that in turn shape the value co-creating relationships between actors. This suggests that designing with resilience in mind also requires a focus on enabling role enactment.

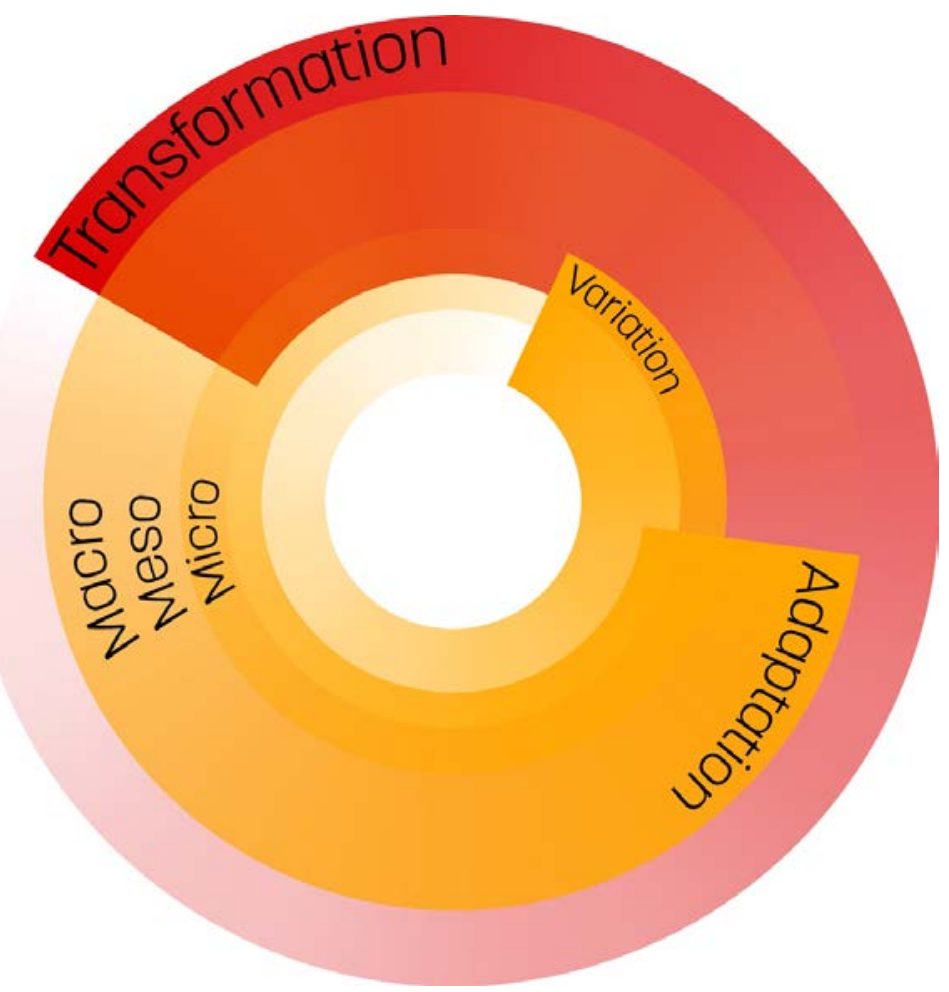

Figure 5.1: Abstract illustration of the interplay of transformability, adaptability and variability across scales. Author's own illustration with base graphic licensed through Shutterstock.com 


\section{Chapter 5}

The findings in this thesis are also in line with Deserti and Rizzo (2014) who present a participatory framework that shows how small-scale experiments can inform policy, but are bound to the creation of networks and partnerships that in turn require new policy development. They emphasise the need for revising processes of change in organisations through "integrating top-down and bottom-up trajectories, breaking the borders between inside and outside, and introducing new forms of participated change management" (Deserti \& Rizzo, 2014, p. 93). A systemic resilience perspective, as presented in this thesis, can strengthen such processes of change through targeted inventions across scales. In her PhD thesis, Vink (2019) tied together Service Design, systems thinking, service-dominant logic (SDL) and institutional theory to build an alternative understanding of Service Design called Service Ecosystem Design. She defines Service Ecosystem Design as "the intentional and collective shaping of social structures, and their physical enactments, in order to facilitate the emergence of cocreated value-in-context" (Vink, 2019, p. v). This view frames Service Design as an ongoing feedback loop involving reflexivity, through which actors become aware of existing social structures, and reformation, through which actors intentionally reshape social structures toward preferred value cocreation configurations. Service Ecosystem Design complements the alternative assumptions of service system resilience and its outlook on shaping transformational change and can be a fruitful perspective for designing for resilience.

One thing that becomes apparent is that designing for resilience requires attention to roles, relationships, process and social structures, indicating an oscillation between multiple scales. The socio-technical nature of service systems indicates that the social aspects of resilience are intertwined with technical aspects of resilience (Taysom \& Crilly, 2017). For example, one informant at Healthcare Inc. describes how they had to switch to filling out forms manually, and using alternative queuing procedures at the healthcare centre when the internet service broke down. Although they had suffered a momentary setback, they could continue working and serving users due to 
the redundancy measures they had come up with it. Therefore, designing for such a coordinated, collective capacity requires not only consideration and development of technological infrastructures as well as the physical environment but also of how the service would continue to be performed when such infrastructures breakdown. In this example, it must be noted that despite technical difficulties adaptability prevailed due to human action. This is consistent with other research, which suggests that social systems increase resilience by being adaptable, while technical systems might hinder the ability to change, even when it is desirable (Taysom \& Crilly, 2017). Taken together, this implies a shifting object of design when designing for service system resilience (Lundberg \& Johansson, 2019), depending on if the designer is aiming for specified or general resilience. This is echoed in Garud and colleagues (2008, p. 354) view on the incompleteness of design, where "the goals and purpose of the design are likely to remain a continually moving target." It is also supported by prior research in urban planning and design, which found that a system's boundaries, purpose, and timescale influence the views of resilience characteristics (Taysom \& Crilly, 2017). By distinguishing between specified and general resilience, adaptability and transformability, and providing a better understanding of these aspects, this work provides direction to answering questions about the resilience of service systems, such as - What kind of change is the system responding to? What aspects of the systems should be resilient? Resilient to what over what time period?

\subsubsection{Implications for Design Practice}

Design research entails the production of knowledge that is useful to those who design (Manzini, 2015). In this thesis, I have framed service system resilience as inextricably linked to actors' coordinated, collective capacity to deal with change. Thus, to contribute to service systems resilience, design practitioners need to focus not only enhancing this collective capacity to respond to change in an ongoing way, but also on nurturing relationships. Using an evolutionary resilience lens, I have distinguished between two 


\section{Chapter 5}

types of resilience characteristics, underpinned by the nature of change adaptation, as a response to more specific type of variations, disruptions or shocks; and transformation, as an ongoing transition characterised by shifts in meaning, network configurations, relationships, and associated organisational and institutional arrangements. This distinction allows better articulation of design aims, depending on the nature of change being addressed. It draws attention to the shifting object of design when designing with resilience in mind. For example, Paper I and II report on the ongoing transition of healthcare systems toward person centred care and how Service Design was used to support this transition. In contrast, adapting to the ongoing pandemic will require a different kind of response and action from designers and those in the field.

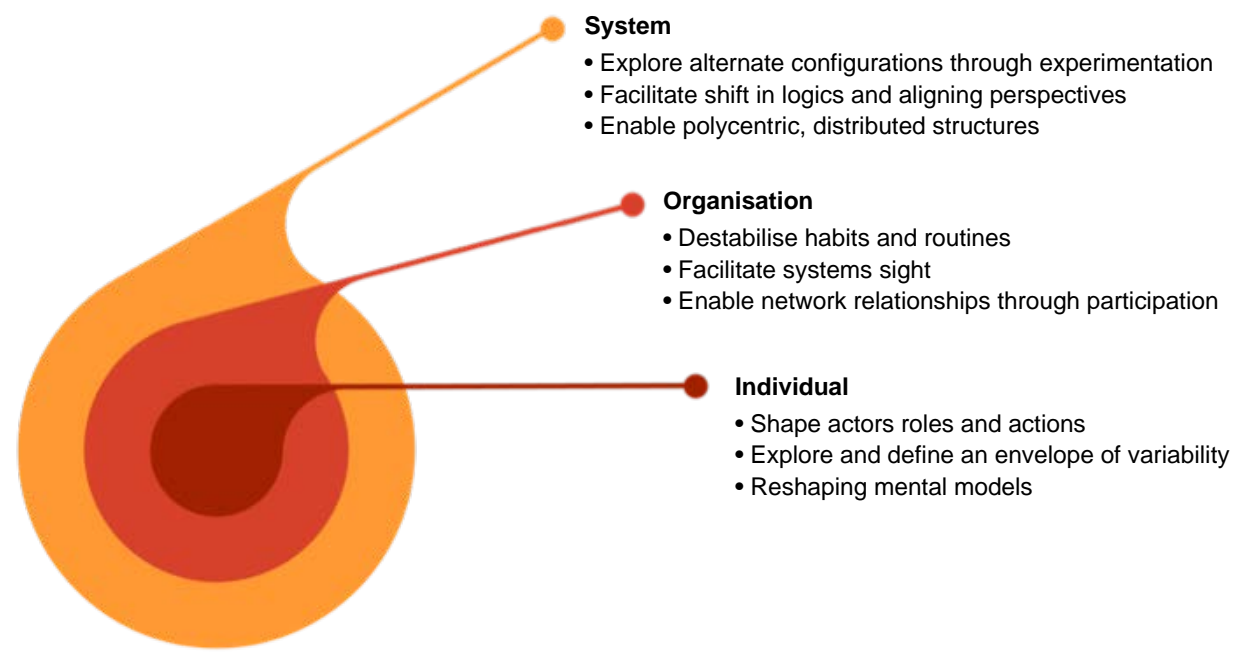

Figure 5.2: Practicing designing for resilience. Author's own illustration.

Figure 5.2 shows where and how practitioners of Service Design may intervene at the micro-individual, meso-organisational and macro-system levels when designing for systemic resilience. For example, service designers could use this framework to leverage their practices to target specific outcomes across different levels, which support systemic resilience. At the individual level, Service Design can enable role enactment to shape 
relationships (Overkamp, 2019), reshape mental models (Vink et al., 2018) and explore and define an envelope of variability (this thesis section 5.3.2). The organisational level entails destabilisation of habits and routines through staging aesthetic disruption (Wetter-Edman et al., 2017), facilitating systems sight (Rye, 2018) and enabling the emergence of network relationships through participation (Steen et al., 2011). At the systemic level, this requires designing for distributed, polycentric structures (this thesis section 5.2.1), stimulating a shift in logics (Kurtmollaiev et al., 2018; Vink et al., 2019) and exploring alternative configurations through experimentation (Blomkvist, 2014; Deserti \& Rizzo, 2014; Karpen et al., 2017). In addition, it explicitly links factors that contribute to resilience with enabling design practices (Paper II).

The patterns of disruption (Paper III) and variations (Paper IV) can serve as generative constructs (Sanders \& Stappers, 2012) to provide a richer basis for exploration in the early phases of the design process. When designing for resilience, it is important to consider service professionals as well as other actors in the service system, and not only the users (Edvardsson \& Olsson, 1996; van der Bijl-Brouwer, 2017). However, such design endeavours are not without challenges. One important factor is acquiring funding for responding to change and/or for remedial action (Olsson, Folke, \& Berkes, 2004). To acquire funding, design practitioners need to communicate and demonstrate the value and impact of such transformative design processes, which is one of the biggest challenges facing practitioners (Burns et al., 2006). The multi-level designing for resilience framework can support targeted interventions to demonstrate the impact and inform the evaluation of ongoing service design efforts and their contributions to systemic resilience. Nonetheless, this research contributes to helping Service Design practitioners understand resilience in service systems and presents an initial framework for intervention points highlighting where service design can contribute towards enabling resilience. 


\section{Chapter 5}

\subsection{Limitations}

As with all other research, this work too has its limitations in relation to the field engagements, frames and approach of the thesis. First, the work in this thesis reflects a primarily provider-side perspective. During the course of my research, I have not interacted with any users, patients or clients myself as part of the data collection barring the observations and one cooking class in the CE2 project. This has been due to accessibility issues and language barriers. The empirical data accordingly reflects a second-hand interpretation of the user perspective and should be understood as such. This research has been carried out exclusively in the healthcare context across all field engagements. This is limiting in the sense that although healthcare shares several characteristics with other services, it is unique in that customers ${ }^{10}$ are at risk, sick, reluctant, relinquish their privacy and need 'whole-person' services (Berry \& Bendapudi, 2007). Owing to this aspect, I have observed that participants tend to be more sympathetic to their users and are motivated to make them feel better. This might not necessarily be the case across other services. The rigid, hierarchical context of healthcare can have helped shed light on designing for systemic resilience that might not have been so visible in other contexts. As such, the findings of this thesis are transferrable at least under similar conditions in service contexts.

Second come the set-up of the field engagements and study design. The selection of these engagements was contingent on my secondments as directed by my involvement in the Service Design for Innovation Network (SDIN). Field engagements 1 and 2 were set-up by the commissioning authority, where teams had to sign up to be part of the Service Design project. The teams consisted almost exclusively of people from non-design backgrounds. During the project, they were guided by project leaders who also did not come from design backgrounds, barring two project leaders in

\footnotetext{
${ }^{10}$ As used in the stream of service literature and original article cited here.
} 
field engagement 2 and a hired service designer in field engagement 1. As a result, the empirical data mainly reflects the experiences and challenges of non-designers and their brush with Service Design. Therefore, there might be more to learn by studying the practice of trained designers. At Healthcare Inc., Service Design had only recently been introduced to the organisation. There was no ongoing project but the service designer was trying to create a holistic picture of the service user journey. Through the interview study, I hoped to reciprocate by identifying pain points in the user journey. However, it is difficult to draw an adequate comparison since there were no practical instances of the design process to analyse. During my time at Healthcare Inc., I regularly discussed my work with my colleagues. Thus, it is expected that some of the findings will also reflect the bias of participants.

Third, although the thesis provides theoretical underpinnings for adaptability across different scales in service systems, it does not explicitly provide empirical support for adaptability at the system level (see Table 5.1). This can be attributed to the nature of the field engagements and the projects undertaken during that time. In this period, none of the participating organisations were subject to abrupt shocks or disruptions at the system scale. For example, the current pandemic crisis would have perhaps provided different insights and exposed system level adaptations in dealing with the crisis. While one can argue that interventions, such as experimentation of alternative configurations, which support systemic transformation could also impact systemic adaptability, claiming this in the light of the empirical data would be reaching into speculative territory.

Other major constraints have been the issues of time and accessibility. At Healthcare Inc., I spent only three months, which is insufficient to understand how Service Design is being adopted in the organisation and what the implications are for developing resilience over the long-term. It was also difficult to conduct workshops and engage with users due to company policy and language barriers. Engagement 1 lasted a year but I was involved only for the latter six months of the project. Therefore, the 


\section{Chapter 5}

findings lean heavily on the prototyping phase, where I actually conducted research. During engagement 2, I could not attend all the sessions since I was based out of Linköping and the sessions took place across Sörmland. Since the core project group was based out of Eskilstuna, they were also able to schedule smaller team sessions more spontaneously. For these, I have had to rely on other forms of data, such as video recordings, photos and reflection diaries, with no first-hand experience. The project in engagement 2 also lasted only 8 months, which again is insufficient to study the anchoring phase.

Lastly, the work in this thesis is also affected by personal and cultural bias. I have an educational and professional background in hospitality and business from India, United Arab Emirates and the Netherlands. My personal view is shaped by my understanding of public healthcare systems and the work cultures in my home country. I have tried to be reflexive about my biases and assumptions. I also acknowledge that in trying to reject these assumptions, I may also be unwittingly reproducing other Western biases through my interpretation of the theories. 


\title{
6 Conclusion
}

\author{
Today is not yesterday. - We ourselves change. - How then, \\ can our works and thoughts, if they are always to be the fittest, \\ continue always the same. - Change, indeed, is painful, yet ever \\ needful; and if memory have its force and worth, so also has \\ hope.
}

-Thomas Carlyle

This chapter summarises the main contributions of this thesis by revisiting the research questions and aims. It also identifies areas for future research.

\subsection{Looking back}

The aim of this thesis is to explore the concept of resilience in service systems, in order to provide a richer understanding of resilience and better account for how Service Design can enable resilience in service systems. Accordingly, two research questions were framed to support this aim:

RQ 1: How should resilience in service systems be understood?

RQ 2: How can Service Design enable resilience in service systems?

The insights and findings from the three field engagements together with the combined theoretical perspectives of service research, Service Design, social-ecological or evolutionary resilience and systems thinking have contributed to a better understanding and advancement of service systems resilience and how it might be nurtured through the practice of Service Design. The contributions in this thesis answer calls for designing resilient 


\section{Chapter 6}

systems (Maglio et al., 2015; Manzini, 2015) by forwarding a richer understanding of resilience in service systems and places to intervene to catalyse resilience through Service Design.

There are three main contributions of this thesis. First, a targeted service literature review reveals a fragmented and reified understanding of the resilience concept. This work problematises the existing view of resilience in service systems and its underlying assumptions. It defines service system resilience as the collective capacity for intentional action in responding to ongoing change, coordinated across scales in order to create value based on the proposed alternative assumptions. Second, building on two approaches to change (i.e., adaptability and transformability) and insights from the empirical material, it articulates the strategic focus and corresponding response actions in order to enable resilience when dealing with different types of change. The adaptive approach emphasises succeeding in varying conditions and making changes within existing systems. The transformative approach recognises that merely making changes to existing systems is not enough, and requires proactive development of new kinds of systems. This work does not privilege one over the other, rather it acknowledges that different approaches are needed over time. By specifying these two approaches to change, it enables service design practitioners to adjust the aims of their practice depending on the nature of change. Third, it provides a practical framework detailing where and how Service Design can intervene in a system to influence factors that enable resilience. By identifying the multi-scalar oscillating nature of resilience in service systems, it highlights the shifting object of Service Design when designing for resilience.

Primarily, this research has shown that while Service Design can serve to cultivate resilience in service systems, such cultivation requires participation, the emergence of networks and leadership, and embedding design capability in service system organisations to enable resilience in an ongoing way. The empirical data shows that Service Design through 
prototyping can foster an appreciation for experimentation in safe arenas. Service Design with its experimental, participatory approach can enable exploration of variability at the micro scale as well as address the configuration of systems relationships at the meso- and macro-scales. The results also show that collaboration is not always a given in network relationships and such relationships can be fraught with tensions. Thus, fostering resilience requires nurturing relationships for collaborative, collective action, since it is human actors who together influence the resilience of service systems. This research contributes to resilience theory by positioning Service Design as an enabler of systemic resilience. In doing so, it extends the transformative potential of the Service Design approach to resilience scholars. It also addresses critique that service researchers borrow theory from a particular discipline without contributing to the borrowed theory (Gustafsson et al., 2016). The work in this thesis might also be of interest to those practicing and researching design for social innovation and sustainability.

\subsection{Looking forward}

Despite its limitations, this work also presents some opportunities for future research at the intersection of service, design, resilience and systems change. The definition and alternative assumptions open up the possibility to move beyond the focus on the individual to investigate resilience at the systems level. There is a need to critique the alternate assumptions presented in the thesis, and problematise other assumptions that might be affecting the understanding of resilience. Further, studies on individual resilience claim that resilience is the least-researched and least-understood psychological capacity (Azab et al., 2018). The targeted nature of the literature review serves as a starting point for a more exhaustive analysis to cover research across a broader range of disciplines spanning individual to system resilience and their intertwined role. 


\section{Chapter 6}

One key area of future research is the relationship between resilience and service innovation. Most studies position Service Design as an enabler of innovation (Overkamp, 2019; Prestes Joly, Teixeira Jorge, Patrício, \& Sangiorgi, 2019; Wetter-Edman et al., 2017). However, service system scholars have theorised that the study of adaptability is essentially the study of innovation (Barile et al., 2016). For example, the adaptive behaviour of actors when responding to disruptions might give rise to innovative ways of value cocreation. How does systemic resilience facilitate or hamper service innovation? There is also the opportunity to explore further how the designing for resilience framework might contribute to system adaptability. Service researchers can explore the synergies between enablers of innovation and resilience and how these two concepts influence each other. For instance, what roles do exploitation and exploration have in relation to transformability and adaptability? Another complementary area is sustainability research and how an understanding of human-centred systems resilience impacts sustainability-oriented services and initiatives. For example, what are the implications of such a resilience capacity for the sharing economy where actors are both providers and users?

Prior research implies that value creation can have negative outcomes when actors in a service system accidently or intentionally misuses their own resources or those of another system by acting in an inappropriate or unexpected way (Plé \& Chumpitaz Cáceres, 2010). Others have also referred to it as the value paradox (Van Riel et al., 2019). There is a need to understand when and how resilience might manifest to the (asymmetrical) detriment of the service system and/or system actors. Longitudinal studies can also explore how resilience evolves over time. Do adaptations to certain kinds of variability make it vulnerable in other aspects? Does an understanding of resilience as an ongoing capability in practice de-emphasise or obscure its importance as a response to crises or shocks? The adaptive and transformative approaches to change as well as its accompanying strategic focus also need to be critically evaluated. How does the linking of adaptability and transformability to resilience in the 
service context affect the myopic practices of organisations? How does this conceptualisation affect the resilience of organisations in the broader system context? What are the unintended consequences of service systems resilience?

While some initial approaches that relate to practicing designing for resilience are posited, future research could more explicitly explore if and how the shifting object of designing for resilience is manifested in practice. What are the challenges associated with this view? How might practitioners overcome these challenges? What are the consequences for managing the design process? Researchers can also build on the identification of cross scale leverage points to develop and adapt service design approaches to intentionally cultivate reflexivity. There is also an opportunity to articulate the role of a professional designer versus practitioners from non-design backgrounds, and create a richer understanding of the differences and similarities of their practice.

Another key area of research involves the politics of participation as an element of enabling resilience. Research on political dimensions of service and design are lacking in current service research narrative (Vink, 2019). However, designing involves shifting and redistributing power within the system, creating future visions of what could be, and the shaping of ideas and alternative governance structures (Akama, 2017; Bratteteig \& Wagner, 2012). Given this power to influence and intervene, we need to be cautious of embedded assumptions and reflexive of our contributions as we continue with our work (Akama, 2017). Research in participatory design highlights several distinctions with regard to who participates, the type of participation, the degree of participation, the duration of participation, and the arena of participation (Bossen et al., 2010; Halskov \& Hansen, 2015). Therefore, further research is required in addressing how these aspects of participation influence system resilience. 



\section{Afterword}

"Why do you go away? So that you can come back. So that you can see the place you came from with new eyes and extra colors. And the people there see you differently, too. Coming back to where you started is not the same as never leaving."

When I started this journey, I carried with me the baggage of prior knowledge, practical experience and unchallenged assumptions. Over the course of this $\mathrm{PhD}$, I have had to unpack this baggage and much more. Pursuing this line of research has been equal parts fascinating, frustrating and fulfilling. I have learnt a lot about service design, resilience and conducting research. The upsides and downsides of this process have helped me grow as a researcher and as a person.

I have faced the mess I unpacked and muddled through hoping to lay the ground work for future research at the intersection of systemic resilience and service design. It is my hope that this research can facilitate shared understanding and provide the impetus for enabling much needed resilience in service systems. I also hope it leads to the recognition of service design 


\section{Afterword}

practice as an important strategic approach for fostering resilience and the ability of critical service systems to adapt and transform over time.

I firmly believe that design can contribute to this endeavour not only in the context of service systems but also at the societal level. Although design cannot do it alone, it is well-equipped to spur collaborative action across the board by creating a space for experimentation, stimulating participation and aligning perspectives on envisioned futures.

As this journey draws to a close, it is time repack - to discard old ideas and assumptions, and take with me new lessons and experiences. I move forward with curiosity and the anticipation of exploring the avenues laid out in my work. The future beckons and new doors await! 


\section{References}

AgenteCOM. (2020). Creativity \& Design in Times of Crisis. Retrieved from https://medium.com/@agentecom/creativity-design-intimes-of-crisis-2e35ef417e13

Aguirre, M., Agudelo, N., \& Romm, J. (2017). Design Facilitation as Emerging Practice: Analyzing How Designers Support Multistakeholder Co-creation. She Ji: The Journal of Design, Economics, and Innovation, 3(3), 198-209.

Aguirre-Ulloa, M., \& Paulsen, A. (2017). Co-designing with relationships in mind. Form Akademisk-forskningstidsskrift for design og designdidaktike, 10(1).

Akaka, M., A., Vargo, S., L., \& Lusch, R., F. (2012). An Exploration of Networks in Value Cocreation: A Service-Ecosystems View. In Special Issue - Toward a Better Understanding of the Role of $V$ alue in Markets and Marketing (pp. 13-50).

Akaka, M., Vargo, S., \& Lusch, R. (2012). An Exploration of Networks in Value Cocreation: A Service-Ecosystems View. In Special Issue Toward a Better Understanding of the Role of $V$ alue in Markets and Marketing (pp. 13-50): Bingley, Emerald Books.

Akaka, M. A., \& Vargo, S. L. (2015). Extending the context of service: from encounters to ecosystems. Journal of Services Marketing, 29(6-7), 453462.

Akama, Y. (2014). Passing on, handing over, letting go-the passage of embodied design methods for disaster preparedness. Paper presented at the Service Design and Innovation Conference.

Akama, Y. (2017). 'With great power comes great responsibility' when we co-create futures. Journal of Marketing Management, 33(3-4), 272-279.

Akgün, A. E., Erdil, O., Keskin, H., \& Muceldilli, B. (2016). The relationship among gratitude, hope, connections, and innovativeness. The Service Industries Journal, 36(3-4), 102-123. 


\section{References}

Akgün, A. E., \& Keskin, H. (2014). Organisational resilience capacity and firm product innovativeness and performance. International Journal of Production Research, 52(23), 6918-6937.

Akgün, A. E., Keskin, H., \& Koçak Alan, A. (2017). Emotional prototypes, emotional memory usages, and customer satisfaction. The Service Industries Journal, 37(7-8), 494-520.

Alam, I., \& Perry, C. (2002). A customer-oriented new service development process. Journal of Services Marketing, 16(6), 515-534.

Alkire, L., Mooney, C., Gur Furkan, A., Kabadayi, S., Renko, M., \& Vink, J. (2019). Transformative service research, service design, and social entrepreneurship: An interdisciplinary framework advancing wellbeing and social impact. Journal of Service Management, 31(1), 24-50.

Allee, V. (2002). A value network approach for modeling and measuring intangibles. Paper presented at the Transparent Enterprise, Madrid.

Allen, C. R., Angeler, D. G., Garmestani, A. S., Gunderson, L. H., \& Holling, C. S. (2014). Panarchy: Theory and Application. Ecosystems, 17(4), 578-589.

Alvesson, M., \& Sandberg, J. (2011). Generating Research Questions Through Problematization. Academy of Management Review, 36(2), 247271. doi:10.5465/amr.2009.0188

Alvesson, M., \& Sköldberg, K. (2009). Reflexive methodology: New vistas for qualitative research (Second ed.). London: Sage.

Anasori, E., Bayighomog, S. W., \& Tanova, C. (2019). Workplace bullying, psychological distress, resilience, mindfulness, and emotional exhaustion. The Service Industries Journal, 1-25.

Anderson, L., \& Ostrom, A. L. (2015). Transformative Service Research:Advancing Our Knowledge About Service and Well-Being. Journal of Service Research, 18(3), 243-249.

Anderson, S., Nasr, L., \& Rayburn, S. W. (2018). Transformative service research and service design: synergistic effects in healthcare. The Service Industries Journal, 38(1-2), 99-113. 
Annala, M., Quaggiotto, G., \& Wong, H. (2020). Experimenting in a time of crisis. In How not to waste a crisis: States of Change.

Ariely, D. (2010). Predictably Irrational, Revised and Expanded Edition: The Hidden Forces That Shape Our Decisions. New York: HarperCollins.

Azab, C., Clark, T., \& Jarvis, C. B. (2018). Positive psychological capacities: the mystery ingredient in successful service recoveries? Journal of Services Marketing, 32(7), 897-912.

Baek, J. S., Meroni, A., \& Manzini, E. (2015). A socio-technical approach to design for community resilience: A framework for analysis and design goal forming. Design Studies, 40, 60-84.

Bailey, S. G. (2012). Embedding service design: the long and the short of it. Paper presented at the ServDes. 2012 Conference Proceedings Co-Creating Services; The 3rd Service Design and Service Innovation Conference; 8-10 February; Espoo; Finland.

Barad, K. (1996). Meeting the universe halfway: Realism and social constructivism without contradiction. In Feminism, science, and the philosophy of science (pp. 161-194): Springer.

Barile, S., Lusch, R., Reynoso, J., Saviano, M., \& Spohrer, J. (2016). Systems, networks, and ecosystems in service research. Journal of Service Management, 27(4), 652-674.

Barile, S., \& Saviano, M. (2011). Foundations of systems thinking: the structure-system paradigm. Various Authors, Contributions to Theoretical and Practical Advances in Management. A Viable Systems Approach (VSA). ASVSA, Associazione per la Ricerca sui Sistemi Vitali. International Printing, 1-24.

Barnes, D., C. , \& Collier, J., E. . (2013). Investigating work engagement in the service environment. Journal of Services Marketing, 27(6), 485-499.

Barnes, D., C. , Collier, J., E. , \& Robinson, S. (2014). Customer delight and work engagement. Journal of Services Marketing, 28(5), 380-390.

Barnett, C. K., \& Pratt, M. G. (2000). From threat-rigidity to flexibility Toward a learning model of autogenic crisis in organizations. Journal of Organizational Change Management, 13(1), 74-88. 


\section{References}

Baron, S., Harris, K., Elliott, D., \& Smith, D. (2005). Business (not) as usual: crisis management, service recovery and the vulnerability of organisations. Journal of Services Marketing, 19(5), 309-320.

Bason, C. (2013). Discovering co-production by design. In E. Manzini \& E. Staszowski (Eds.), Public and collaborative: Exploring the intersections of design, social innovation and publicpolicy (pp. viii-xvi). New York: DESIS Network.

Bell, C., \& Zemke, R. (1987). Service Breakdown: The Road to Recovery. Management Review, 76(10), 32.

Berry, L. L., \& Bendapudi, N. (2007). Health Care:A Fertile Field for Service Research. Journal of Service Research, 10(2), 111-122. doi:10.1177/1094670507306682

Bhamra, R., Dani, S., \& Burnard, K. (2011). Resilience: the concept, a literature review and future directions. International Journal of Production Research, 49(18), 5375-5393.

Biemans, W. G., Griffin, A., \& Moenaert, R. K. (2016). Perspective: New Service Development: How the Field Developed, Its Current Status and Recommendations for Moving the Field Forward. Journal of Product Innovation Management, 33(4), 382-397.

Biggs, R., Schlüter, M., Biggs, D., Bohensky, E. L., BurnSilver, S., Cundill, G., . . . West, P. C. (2012). Toward Principles for Enhancing the Resilience of Ecosystem Services. Annual Review of Environment and Resources, 37(1), 421-448.

Bitner, M. (1992). Servicescapes: The Impact of Physical Surroundings on Customers and Employees. Journal of Marketing, 56(2), 57-71.

Bitner, M., Booms, B., \& Tetreault, M. (1990). The service encounter: diagnosing favorable and unfavorable incidents. Journal of Marketing, 54(1), 71-84.

Bjögvinsson, E., Ehn, P., \& Hillgren, P.-A. (2012). Design Things and Design Thinking: Contemporary Participatory Design Challenges. Design Issues, 28(3), 101-116.

Blomberg, J., \& Darrah, C. (2015). Towards an Anthropology of Services. The Design Journal, 18(2), 171-192. 
Blomkvist, J. (2012). Conceptualisations of service prototyping: service sketches, walkthroughs and live service prototypes. In S. Miettinen \& A. Valtonen (Eds.), Service Design with Theory: Discussions on Change, $V$ alue and Methods (pp. 177-188). Vantaa, Finland: Lapland University Press.

Blomkvist, J. (2014). Representing future situations of service: prototyping in service design. Linkoping University,

Blomkvist, J. (2015). In-house service design roles - a first look. Paper presented at the IASDR 2015 Interplay, Brisbane.

Blomkvist, J., \& Bode, A. (2012). Using service walkthroughs to co-create whole service experiences. International Service Innovation Design Conference.

Blomkvist, J., Clatworthy, S., \& Holmlid, S. (2016). Ways of seeing the design material of service. Paper presented at the Service Design Geographies. The ServDes. 2016 Conference, Copenhagen 24-26 May 2016.

Blomkvist, J., Fjuk, A., \& Sayapina, V. (2016). Low Threshold Service Design: Desktop Walkthrough. Paper presented at the Service Design Geographies. Proceedings of the ServDes2016 Conference.

Blomkvist, J., \& Holmlid, S. (2010). Service prototyping according to service design practitioners. In Conference Proceedings, ServDes. 2010, Exchanging Knowledge, Linköping, Sweden, 1-3 December 2010 (Vol. 2, pp. 1-11). Linköping University Electronic Press.

Blomkvist, J., Holmlid, S., \& Segelström, F. (2010). Service design research: Yesterday, today and tomorrow. In M. Stickdorn \& J. Schneider (Eds.), This is service design thinking (pp. 308-315): Amsterdam: BIS Publishers.

Boin, A., Comfort, L. K., \& Demchak, C. C. (2010). The rise of resilience. Designing resilience: Preparing for extreme events, 1.

Borchert, I., \& Mattoo, A. (2010). The crisis-resilience of services trade. The Service Industries Journal, 30(13), 2115-2136. 


\section{References}

Bossen, C., Dindler, C., \& Iversen, O. S. (2010). User gains and PD aims: assessment from a participatory design project. Paper presented at the Proceedings of the 11th Biennial Participatory Design Conference, Sydney, Australia.

Bowers, M. (1986). New Service Product Development in Service Industries. PhD Dissertation, Texas A \& M University, College Station,

Bratteteig, T., \& Wagner, I. (2012). Disentangling power and decision-making in participatory design. Paper presented at the Proceedings of the 12th Participatory Design Conference: Research Papers - Volume 1, Roskilde, Denmark.

Brinkmann, S., \& Kvale, S. (2015). Interviews: Learning the craft of qualitative research interviewing (Vol. 3): Sage Thousand Oaks, CA.

Briscoe, G., Keränen, K., \& Parry, G. (2012). Understanding complex service systems through different lenses: An overview. European Management Journal, 30(5), 418-426.

Brown, T. (2008). Design thinking. Harvard Business Review, 86(6), 84-93.

Brown, T. (2009). Change by design: How design thinking creates new alternatives for business and society: Collins Business.

Bruneau, M., Chang, S. E., Eguchi, R. T., Lee, G. C., O'Rourke, T. D., Reinhorn, A. M., . . . Winterfeldt, D. v. (2003). A Framework to Quantitatively Assess and Enhance the Seismic Resilience of Communities. Earthquake Spectra, 19(4), 733-752.

Buchanan, R. (1992). Wicked problems in design thinking. Design Issues, 8(2), $5-21$.

Buchanan, R. (2001). Design Research and the New Learning. Design Issues, 17(4), 3-23.

Bullinger, H.-J., Fähnrich, K.-P., \& Meiren, T. (2003). Service engineeringmethodical development of new service products. International Journal of Production Economics, 85(3), 275-287.

Burns, C., Cottam, H., Vanstone, C., \& Winhall, J. (2006). RED paper 02: Transformation design. In: London: Design Council. 
Čaić, M., Odekerken-Schröder, G., \& Mahr, D. (2018). Service robots: value co-creation and co-destruction in elderly care networks. Journal of Service Management, 29(2), 178-205.

Carpenter, S., Walker, B., Anderies, J. M., \& Abel, N. (2001). From Metaphor to Measurement: Resilience of What to What? Ecosystems, 4(8), 765-781.

Cheung, L., McColl-Kennedy, J., R., \& Coote, L., V. (2017). Consumercitizens mobilizing social capital following a natural disaster: effects on well-being. Journal of Services Marketing, 31(4/5), 438-451.

Chou, C., Hsu, Y.-H., \& Goo, Y.-J. (2009). Service failures and recovery strategies from the service provider perspective. Asia Pacific Management Review, 237-249.

Christopher, M., \& Peck, H. (2004). Building the Resilient Supply Chain. The International Journal of Logistics Management, 15(2), 1-14.

Clatworthy, S. (2011). Service innovation through touch-points: Development of an innovation toolkit for the first stages of new service development. International Journal of Design, 5(2).

Cohen, L., Manion, L., Morrison, K., \& Morrison, R. (2007). Research methods in education In. New York: Routledge.

Commission, E. (2014). On Effective, Accessible and Resilient Health Systems. Retrieved from Brussels: https://ec.europa.eu/health/sites/health/files/systems_performan ce_assessment/docs/com2014_215_final_en.pdf

Cooper, R. G., \& de Brentani, U. (1991). New industrial financial services: What distinguishes the winners. Journal of Product Innovation Management, 8(2), 75-90.

Costa, N., Patrício, L., \& Morelli, N. (2018). A designerly-way of conducting qualitative research in design studies. Paper presented at the ServDes2018. Service Design Proof of Concept, Proceedings of the ServDes. 2018 Conference, 18-20 June, Milano, Italy.

Cowley, R., Barnett, C., Katzschner, T., Tkacz, N., \& De Boeck, F. (2018). Forum: resilience \& design. Resilience, 6(1), 1-34. 


\section{References}

Creswell, J. W., \& Poth, C. N. (2018). Qualitative inquiry and research design: Choosing among five approaches (Fourth ed.). Thousand Oaks: Sage publications.

Cunha, M. P. e., Cunha, J. V. d., \& Kamoche, K. (1999). Organizational Improvisation: What, When, How and Why. International Journal of Management Reviews, 1(3), 299-341.

Cuvelier, L., \& Falzon, P. (2010). Coping with uncertainty: resilient decisions in anaesthesia. Resilience engineering in practice: a guidebook, 2943.

Davoudi, S., Shaw, K., Haider, L. J., Quinlan, A. E., Peterson, G. D., Wilkinson, C., ... Davoudi, S. (2012). Resilience: A Bridging Concept or a Dead End? "Reframing" Resilience: Challenges for Planning Theory and Practice Interacting Traps: Resilience Assessment of a Pasture Management System in Northern Afghanistan Urban Resilience: What Does it Mean in Planning Practice? Resilience as a Useful Concept for Climate Change Adaptation? The Politics of Resilience for Planning: A Cautionary Note. Planning Theory \& Practice, 13(2), 299-333.

de Brentani, U. (1989). Success and failure in new industrial services. Journal of Product Innovation Management, 6(4), 239-258.

De Bruijne, M., Boin, A., \& Van Eeten, M. (2010). Resilience: Exploring the concept and its meanings. Designing resilience: Preparing for extreme events, 13-32.

Denzin, N. K., \& Lincoln, Y. S. (2011). The Sage handbook of qualitative research. Thousand Oaks: Sage Publications Inc.

Deserti, A., \& Rizzo, F. (2014). Design And Organisational change In the Public Sector. Paper presented at the Design Management in the era of disruption.

Dorst, K. (2019). Design beyond Design. She Ji: The Journal of Design, Economics, and Innovation, 5(2), 117-127.

Dorst, K., \& Cross, N. (2001). Creativity in the design process: co-evolution of problem-solution. Design Studies, 22(5), 425-437. 
Dubberly, H., \& Evenson, S. (2010). Designing for service: creating an experience advantage. In G. Salvendy \& W. Karwowski (Eds.), Introduction to Service Engineering (pp. 403-413): Wiley.

Edvardsson, B. (1997). Quality in new service development: key concepts and a frame of reference. International Journal of Production Economics, 52(1), 31-46.

Edvardsson, B., Gustafsson, A., \& Roos, I. (2005). Service portraits in service research: a critical review. International Journal of Service Industry Management, 16(1), 107-121.

Edvardsson, B., Haglund, L., \& Mattsson, J. (1995). Analysis, planning, improvisation and control in the development of new services. International Journal of Service Industry Management, 6(2), 24-35.

Edvardsson, B., \& Olsson, J. (1996). Key concepts for new service development. Service Industries Journal, 16(2), 140-164.

Edvardsson, B., \& Tronvoll, B. (2013). A new conceptualization of service innovation grounded in S-D logic and service systems. International Journal of Quality and Service Sciences, 5(1), 19-31.

Fayard, A.-L., Stigliani, I., \& Bechky, B. A. (2017). How Nascent Occupations Construct a Mandate: The Case of Service Designers' Ethos. Administrative Science Quarterly, 62(2), 270-303.

Fiksel, J. (2003). Designing Resilient, Sustainable Systems. Environmental Science \& Technology, 37(23), 5330-5339.

Fisk Raymond, P., Dean Alison, M., Alkire, L., Joubert, A., Previte, J., Robertson, N., \& Rosenbaum Mark, S. (2018). Design for service inclusion: creating inclusive service systems by 2050. Journal of Service Management, 29(5), 834-858.

Flanagan, J. C. (1954). The critical incident technique. Psychological bulletin, $51(4), 327$.

Flick, U. (2018). Triangulation in data collection. The SAGE Handbook of Qualitative Data Collection. London, UK: SAGE Publications. 


\section{References}

Folke, C., Carpenter, S. R., Walker, B., Scheffer, M., Chapin, T., \& Rockström, J. (2010). Resilience Thinking: Integrating Resilience, Adaptability and Transformability. Ecology and Society, 15(4), 20.

Folke, C., Colding, J., \& Berkes, F. (2002). Synthesis: building resilience and adaptive capacity in social-ecological systems. In C. Folke, F. Berkes, \& J. Colding (Eds.), Navigating Social-Ecological Systems: Building Resilience for Complexity and Change (pp. 352-387). Cambridge: Cambridge University Press.

Følstad, A., \& Kvale, K. (2018). Customer journeys: a systematic literature review. Journal of Service Theory and Practice.

Frei, F. X. (2006). Breaking the trade-off between efficiency and service. Harvard Business Review, 84(11), 92-101.

Frow, P., McColl-Kennedy, J. R., Hilton, T., Davidson, A., Payne, A., \& Brozovic, D. (2014). Value propositions: A service ecosystems perspective. Marketing Theory, 14(3), 327-351.

Garud, R., Jain, S., \& Tuertscher, P. (2008). Incomplete by Design and Designing for Incompleteness. Organization Studies, 29(3), 351-371.

Giddens, A. (1984). The constitution of society: outline of the theory of structuration. California: University of California Press.

Goldstein, S., Johnston, R., Duffy, J., \& Rao, J. (2002). The service concept: the missing link in service design research? Journal of Operations Management, 20(2), 121-134.

Graneheim, U. H., \& Lundman, B. (2004). Qualitative content analysis in nursing research: concepts, procedures and measures to achieve trustworthiness. Nurse Educ Today, 24(2), 105-112.

Grönroos, C. (2001). Service management and marketing:a customer relationship management approach. Chichester: John Wiley \& Sons.

Grönroos, C. (2006). Adopting a service logic for marketing. Marketing Theory, 6(3), 317-333.

Grönroos, C. (2008). Service logic revisited: who creates value? And who co-creates? European Business Review, 20(4), 298-314. 
Grönroos, C., \& Ravald, A. (2011). Service as business logic: implications for value creation and marketing. Journal of Service Management, 22(1), $5-22$.

Grönroos, C., \& Voima, P. (2013). Critical service logic: making sense of value creation and co-creation. Journal of the Academy of Marketing Science, 41(2), 133-150.

Gummesson, E. (1989). Nine Lessons on Service Quality. The TQM Magazine, 1(2).

Gummesson, E. (2008). Extending the service-dominant logic: from customer centricity to balanced centricity. Journal of the Academy of Marketing Science, 36(1), 15-17.

Gummesson, E., \& Mele, C. (2010). Marketing as value co-creation through network interaction and resource integration. Journal of Business Market Management, 4(4), 181-198.

Gupta, M., Shaheen, M., \& Das, M. (2018). Engaging employees for quality of life: mediation by psychological capital. The Service Industries Journal, 39(5-6), 403-419.

Gustafsson, A., Anders, G., Professor Rod, P., Högström, C., Radnor, Z., Friman, M., ... Mele, C. (2016). Developing service research - paving the way to transdisciplinary research. Journal of Service Management, 27(1), 9-20.

Halskov, K., \& Hansen, N. B. (2015). The diversity of participatory design research practice at PDC 2002-2012. International Journal of HumanComputer Studies, 74, 81-92.

Halvorsrud, R., Kvale, K., \& Følstad, A. (2016). Improving service quality through customer journey analysis. Journal of Service Theory and Practice, $26(6), 840-867$.

Haraway, D. (1988). Situated Knowledges: The Science Question in Feminism and the Privilege of Partial Perspective. Feminist Studies, 14(3), 575-599.

Helkkula, A., Linna, M., \& Kelleher, C. (2013). Health, cost, prevention and cure-value and value cocreation in public healthcare. Paper presented at the Naples Forum on Service, Naples, Italy. 


\section{References}

Holling, C., S. (1973). Resilience and Stability of Ecological Systems. Annual Review of Ecology and Systematics, 4(1), 1-23.

Holling, C., S. (1996). Engineering resilience versus ecological resilience. Engineering within ecological constraints, 31(1996), 32.

Holling, C., S., \& Gunderson, L. H. (2002). Panarchy: understanding transformations in human and natural systems. Washington, DC: Island Press.

Holling, C. S. (1973). Resilience and Stability of Ecological Systems. Annual Review of Ecology and Systematics, 4(1), 1-23.

Hollnagel, E. (2014). Resilience engineering and the built environment. Building Research \& Information, 42(2), 221-228.

Holmlid, S. (2007). Interaction design and service design: Expanding a comparison of design disciplines. Paper presented at the 2nd Nordic Design Research Design Conference, Stockholm, Sweden.

Holmlid, S. (2009). Participative, cooperative, emancipatory: From participatory design to service design. Paper presented at the $1 \mathrm{st}$ Nordic Conference on Service Design and Service Innovation, Oslo, Norway.

Holmlid, S. (2012). Designing for Resourcefulness in Service : Some Assumptions and Consequences. In A. V. Satu Miettinen (Ed.), Service Design with Theory: Discussions on Change, Value and Methods (pp. 151172): Lapland University Press.

Holmlid, S. (2014). One approach to understand design's value under a service logic. Paper presented at the 19th DMI Academic Design Management Conference.

Holmlid, S., \& Evenson, S. (2007). Prototyping and enacting services: Lessons learned from human-centered methods. Paper presented at the Proceedings from the 10th Quality in Services conference, QUIS.

Holmlid, S., \& Evenson, S. (2008). Bringing service design to service sciences, management and engineering. In Service science, management and engineering education for the 21 st century: Springer US. 
Holmlid, S., Mattelmäki, T., Visser, F. S., \& Vaajakallio, K. (2015). Cocreative practices in service innovation. In R. Agarwal, W. Selen, G. Roos, \& R. Green (Eds.), The Handbook of Service Innovation (pp. 545574): Springer.

Holmlid, S., Wetter-Edman, K., \& Edvardsson, B. (2017). Breaking free from NSD: Design and service beyond new service development. Designing for service-key issues and new directions, 95-104.

Höök, K., \& Löwgren, J. (2012). Strong concepts: Intermediate-level knowledge in interaction design research. ACM Transactions on Computer-Human Interaction, 19(3), 1-18.

Hsieh, H.-F., \& Shannon, S. E. (2005). Three Approaches to Qualitative Content Analysis. Qualitative Health Research, 15(9), 1277-1288.

Huan, Y., Arvola, M., \& Holmlid, S. (2020). Three Perspectives on Inclusive Service Design: User-Centred, Adaptive Systems, and Service Logics. Paper presented at the ServDes.2020 - Tensions, Paradoxes, Plurality, Melbourne, Australia.

Janssen, M. A., Anderies, J. M., \& Ostrom, E. (2007). Robustness of SocialEcological Systems to Spatial and Temporal Variability. Society \& Natural Resources, 20(4), 307-322.

Johnson, S. P., Menor, L. J., Roth, A. V., \& Chase, R. B. (2000). A Critical Evaluation of The New Service Development Process. In J. Fitzsimmons \& M. Fitzsimmons (Eds.), New Service Development: Creating Memorable Experiences (pp. 1-32). Thousand Oaks, CA: Sage.

Junginger, S., \& Sangiorgi, D. (2009). Service design and organizational change: Bridging the gap between rigour and relevance. Paper presented at the Proceedings of the 3rd IASDR Conference on Design Research.

Kaplan, B., \& Maxwell, J. (1994). Evaluating health care information systems: Methods and applications. Qualitative Research Methods for Evaluating Computer Information Systems. JG Anderson, CE Ayden and SJ Jay. Thousand Oaks, Sage. 


\section{References}

Karpen, I. O., Gemser, G., \& Calabretta, G. (2017). A multilevel consideration of service design conditions: Towards a portfolio of organisational capabilities, interactive practices and individual abilities. Journal of Service Theory and Practice, 27(2), 384-407.

Kimbell, L. (2009a). Beyond design thinking: design-as-practice and designs-inpractice. Paper presented at the CRESC Conference, Manchester.

Kimbell, L. (2009b). The turn to service design. Design and creativity: Policy, management and practice, 157-173.

Kimbell, L. (2011). Designing for service as one way of designing services. International Journal of Design, 5(2), 41-52.

Kimbell, L., \& Blomberg, J. (2017). The object of service design. In D. Sangiorgi \& A. Prendiville (Eds.), Designing for Service: Key Issues and New Directions; Bloomsbury Publishing: London, UK (pp. 81).

Klein, R. J. T., Nicholls, R. J., \& Thomalla, F. (2003). Resilience to natural hazards: How useful is this concept? Environmental Hazards, 5(1), 3545 .

Koivisto, M. (2009). Frameworks for structuring services and customer experiences. In S. Miettinen \& M. Koivisto (Eds.), Designing services with innovative methods (pp. 136-149): Helsinki University of Art and Design.

Korper, A. K., Holmlid, S., \& Patricio, L. (2018). Bridging design-driven and service innovation: Consonance and dissonance of meaning and value. Paper presented at the ServDes2018. Service Design Proof of Concept, Proceedings of the ServDes. 2018 Conference, 18-20 June, Milano, Italy.

Kothandaraman, P., \& Wilson, D. (2001). The future of competition: valuecreating networks. Industrial Marketing Management, 30(4), 379-389.

Kurtmollaiev, S., Fjuk, A., Pedersen, P. E., Clatworthy, S., \& Kvale, K. (2018). Organizational Transformation Through Service Design:The Institutional Logics Perspective. Journal of Service Research, 21(1), 5974.

Larson, R. C. (2016). Commentary—Smart service systems: Bridging the silos. Service Science, 8(4), 359-367. 
Lassila, S., Rieple, A., \& Ennis, C. (2017). A model of service design elements to understand innovative service processes. The Design Management Academy: Research Perspectives on Creative Intersections, 4, 13431360.

Laud, G., Bove, L., Ranaweera, C., Leo Wei Wei, C., Sweeney, J., \& Smith, S. (2019). Value co-destruction: a typology of resource misintegration manifestations. Journal of Services Marketing, 33(7), 866-889.

Law, J. (2006). Making a Mess with Method, version of 19th January 2006. Retrieved from:

http:// www.heterogeneities.net/publications/Law2006MakingaMesswithMet bod.pdf,.

Legaspi, R., Maruyama, H., Nararatwong, R., \& Okada, H. (2014, 3-5 Dec. 2014). Perception-Based Resilience: Accounting for the Impact of Human Perception on Resilience Thinking. Paper presented at the 2014 IEEE Fourth International Conference on Big Data and Cloud Computing.

Legeby, M., McAleenan, P., Andersson, H., \& Holmlid, S. (2018). Guiding the welfare state towards a co-creative and explorative mindset: When a crisis is an opportunity. Paper presented at the ServDes2018. Service Design Proof of Concept, Proceedings of the ServDes. 2018 Conference, 1820 June, Milano, Italy.

Lengnick-Hall, C. A., Beck, T. E., \& Lengnick-Hall, M. L. (2011). Developing a capacity for organizational resilience through strategic human resource management. Human Resource Management Review, $21(3), 243-255$.

Lin, J. (2014). Design capabilities in public sector. Paper presented at the Design Management in an Era of Disruption Proceedings of the 19th DMI: Academic Design Management Conference.

Lincoln, Y. S., \& Guba, E. G. (1985). Naturalistic Inquiry. Beverly Hills, CA: Sage.

Loomba, A., P.S.,. (2017). Reconstructing lives: transformative services for human trafficking survivors. Journal of Services Marketing, 31(4/5), 373384. 


\section{References}

Lovelock, C., \& Gummesson, E. (2004). Whither Services Marketing?: In Search of a New Paradigm and Fresh Perspectives. Journal of Service Research, 7(1), 20-41.

Lundberg, J., \& Johansson, B. J. E. (2019). Resilience is not a silver bullet Harnessing resilience as core values and resource contexts in a double adaptive process. Reliability Engineering \& System Safety, 188, 110-117.

Lusch, R., F., Sagarin, R., \& Tang, Z. (2016). Commentary-Lessons from Nature: Enhancing the Adaptable Potential of Service Ecosystems. Service Science, 8(1), 85-96. doi:10.1287/serv.2016.0127

Lusch, R., \& Vargo, S. (2014). Service-dominant logic: premises, perspectives, possibilities: Cambridge University Press.

Lusch, R. F., \& Spohrer, J. C. (2012). Evolving service for a complex, resilient, and sustainable world. Journal of Marketing Management, 28(1314), 1491-1503.

Luthans, F., Youssef, C. M., \& Avolio, B. J. (2007). Psychological capital: Developing the buman competitive edge. New York: Oxford University Press.

Luthar, S. S., Cicchetti, D., \& Becker, B. (2000). The Construct of Resilience: A Critical Evaluation and Guidelines for Future Work. Child Development, 71(3), 543-562.

Mager, B. (2009). Service design as an emerging field. In S. Miettinen \& M. Koivisto (Eds.), (pp. 28-43).

Maglio, P., Kwan, S., K. , \& Spohrer, J. (2015). Commentary-Toward a Research Agenda for Human-Centered Service System Innovation. Service Science, 7(1), 1-10.

Maglio, P., \& Spohrer, J. (2008). Fundamentals of service science. Journal of the Academy of Marketing Science, 36(1), 18-20.

Maglio, P., Srinivasan, S., Kreulen, J., \& Spohrer, J. (2006). Service systems, service scientists, SSME, and innovation. Commun. ACM, 49(7), 8185. 
Maglio, P., Vargo, S., Caswell, N., \& Spohrer, J. (2009). The service system is the basic abstraction of service science. Information Systems and eBusiness Management, 7(4), 395-406.

Malmberg, L. (2017). Building Design Capability in the Public Sector: Expanding the Horizons of Development (Vol. 1831): Linköping University Electronic Press.

Malmberg, L., \& Wetter-Edman, K. (2016). Design in public sector: Exploring antecedents of sustained design capability. Paper presented at the 20th DMI: Academic Design Management Conference-Inflection Point: Design Research Meets Design Practice, Boston, USA, July 22-29, 2016.

Manzini, E. (2015). Design, when everybody designs: An introduction to design for social innovation: MIT press.

Mars, M. M., Bronstein, J. L., \& Lusch, R. F. (2012). The value of a metaphor. Organizational Dynamics, 41(4), 271-280.

Maxwell, J. A., \& Chmiel, M. (2014). Generalization in and from qualitative analysis. In The SAGE bandbook of qualitative data analysis (pp. 540-553). London: Sage Publications Ltd.

McCormack, B., \& McCance, T. V. (2006). Development of a framework for person-centred nursing. Journal of Advanced Nursing, 56(5), 472479.

Mead, N., \& Bower, P. (2000). Patient-centredness: a conceptual framework and review of the empirical literature. Social Science \& Medicine, 51(7), 1087-1110.

Mele, C., \& Polese, F. (2011). Key Dimensions of Service Systems in ValueCreating Networks. In H. Demirkan, C. J. Spohrer, \& V. Krishna (Eds.), The Science of Service Systems (pp. 37-59). Boston, MA: Springer US.

Meroni, A. (2007). Creative Communities. People inventing sustainable ways of living: Edizioni Polidesign.

Meroni, A., \& Sangiorgi, D. (2011). Design for services: Gower Publishing.

Merriam, S. B. (1998). Qualitative Research and Case Study Applications in Education. : ERIC. 


\section{References}

Misco, T. (2007). The frustrations of reader generalizability and grounded theory: Alternative considerations for transferability. Journal of Research Practice, 3(1), 10.

Moeller, S. (2010). Characteristics of services - a new approach uncovers their value. Journal of Services Marketing, 24(5), 359-368.

Mulgan, G. (2020). How not to waste a crisis. Retrieved from https://www.geoffmulgan.com/post/how-not-to-waste-a-crisispossibilities-for-government-after-covid-19

Navarro-Espigares, J. L., Martín-Segura, J. A., \& Hernández-Torres, E. (2012). The role of the service sector in regional economic resilience. The Service Industries Journal, 32(4), 571-590.

Nilsson, A. W., \& Jahnke, M. (2018). Tactics for Norm-Creative Innovation. She Ji: The Journal of Design, Economics, and Innovation, 4(4), 375-391.

Norman, D. (1998). The design of everyday things: London: MIT.

Norman, D. A., \& Stappers, P. J. (2015). DesignX: Complex Sociotechnical Systems. She Ji: The Journal of Design, Economics, and Innovation, 1(2), 83106.

Normann, R. (2001). Reframing business: when the map changes the landscape: John Wiley \& Sons.

Normann, R., \& Ramírez, R. (1993). Designing interactive strategy. Harvard Business Review, 71(4), 65-77.

Olsson, P., Folke, C., \& Berkes, F. (2004). Adaptive Comanagement for Building Resilience in Social-Ecological Systems. Environmental Management, 34(1), 75-90.

Olsson, P., Folke, C., \& Hahn, T. (2004). Social-ecological transformation for ecosystem management: the development of adaptive comanagement of a wetland landscape in southern Sweden. Ecology and Society, 9(4). 
Olsson, P., Gunderson, L. H., Carpenter, S. R., Ryan, P., Lebel, L., Folke, C., \& Holling, C. S. (2006). Shooting the Rapids: Navigating Transitions to Adaptive Governance of Social-Ecological Systems. Ecology and Society, 11(1).

Ostrom, A., Parasuraman, A., Bowen, D., Patrício, L., Voss, C., \& Lemon, K. (2015). Service research priorities in a rapidly changing context. Journal of Service Research, 18(2), 127-159.

Overkamp, T. (2019). How Service Ideas Are Implemented: Ways of Framing and Addressing Service Transformation. Linköping University Electronic Press, Linköping.

Overkamp, T., \& Holmlid, S. (2016). Views on implementation and how they could be used in service design. Paper presented at the Service Design Geographies. Proceedings of the ServDes, 2016 Conference, May 2426, Copenhagen, Denmark, Linköping.

Overkamp, T., \& Holmlid, S. (2017). Evolutions of service actor roles towards future service. Paper presented at the Nordes 2017, the 7th Nordic Design Research Conference, Design+ Power, 15-17 June, 2017, Oslo, Norway.

Pacenti, E., \& Sangiorgi, D. (2010). Service design research pioneers: An overview of service design research developed in italy since the ' $90 \mathrm{~s}$. Design Research Journal, 1(1), 26-33.

Parker, S., \& Heapy, J. (2006). The journey to the interface. London: Demos.

Patrício, L., Fisk, R., Falcão e Cunha, J., \& Constantine, L. (2011). Multilevel service design: from customer value constellation to service experience blueprinting. Journal of Service Research, 14(2), 180-200.

Patrício, L., Gustafsson, A., \& Fisk, R. (2018). Upframing Service Design and Innovation for Research Impact. Journal of Service Research, 21(1), 3-16.

Peltonen, S. (2017). Changing roles. Role theoretical approach to customer involvement in industrial service development. The Design Journal, 20(sup1), S2605-S2615. 


\section{References}

Pendall, R., Foster, K. A., \& Cowell, M. (2010). Resilience and regions: building understanding of the metaphor. Cambridge Journal of Regions, Economy and Society, 3(1), 71-84.

Penin, L., \& Tonkinwise, C. (2009). The Politics and Theatre of Service Design. Paper presented at the IASDR, Seoul, Korea.

Pina e Cunha, M., Rego, A., \& Kamoche, K. (2009). Improvisation in service recovery. Managing Service Quality: An International Journal, 19(6), 657-669.

Plé, L., \& Chumpitaz Cáceres, R. (2010). Not always co-creation: introducing interactional co-destruction of value in service-dominant logic. Journal of Services Marketing, 24(6), 430-437.

Prestes Joly, M., Teixeira Jorge, G., Patrício, L., \& Sangiorgi, D. (2019). Leveraging service design as a multidisciplinary approach to service innovation. Journal of Service Management, 30(6), 681-715.

Rittel, H., \& Webber, M. (1973). Dilemmas in a general theory of planning. Policy Sciences, 4(2), 155-169.

Rodrigues, V., Blomkvist, J., \& Holmlid, S. (2018). Perceived Action Potential: A strong concept in development. Paper presented at the ServDes2018. Service Design Proof of Concept, Proceedings of the ServDes. 2018 Conference, 18-20 June, Milano, Italy.

Rodrigues, V., \& Holmlid, S. (2017). Discovering Service Variations through Service Prototyping. The Design Journal, 20(sup1), S2247S2257.

Rodrigues, V., \& Vink, J. (2016). Shaking up the status quo in healthcare: Designing amid conflicting enacted social structures. Paper presented at the Relating Systems Thinking and Design Symposium (RSD), 13-15 Oct 2016, Toronto, Canada.

Rosengren, K. E. (1981). Advances in Scandinavia content analysis: An introduction. In K. E. Rosengren (Ed.), Advances in content analysis (pp. 9-19). Beverly Hills, CA: Sage.

Rye, S. (2018). Kanopi: how might we improve the environmental and social outcomes of biodiversity conservation projects?: an exegesis submitted in partial fulfilment of 
the requirements for the degree of Master of Design, Massey University, Te Kunenga Ki Pürehuroa, Wellington, Aotearoa New Zealand. Massey University,

Sanders, E., B. N., \& Stappers, P., J. (2008). Co-creation and the new landscapes of design. CoDesign, 4(1), 5-18.

Sanders, E.-N. (2000). Generative tools for co-designing. In Collaborative design (pp. 3-12): Springer.

Sanders, E. B. N., \& Stappers, P. J. (2012). Convivial toolbox: Generative research for the front end of design. Amsterdam: BIS Publishers.

Sangiorgi, D. (2010). Transformative services and transformation design. International Journal of Design, 5(2), 29-40.

Sangiorgi, D., \& Clark, B. (2004). Toward a participatory design approach to service design. Paper presented at the PDC.

Sangiorgi, D., Patrício, L., \& Fisk, R. P. (2017). Designing for interdependence, participation and emergence in complex service systems. In Designing for service: Key issues and new directions (pp. 49-64).

Sangiorgi, D., \& Prendiville, A. (2014). A theoretical framework for studying service design practices: first steps to a mature field. Design Management Journal, 9(1), 61-73.

Scheuing, E., \& Johnson, E. (1989). A proposed model for new service development. Journal of Services Marketing, 3(2), 25-34.

Schön, D. (1983). The Reflective Practitioner: How Professionals Think in Action: Basic Books, Cambridge, MA.

Secchi, E., Roth, A., \& Verma, R. (2016). The role of service improvisation in improving hotel customer satisfaction. Cornell Hospitably Report, 16(1), 3-10.

Secomandi, F., \& Snelders, D. (2011). The Object of Service Design. Design Issues, 27(3), 20-34. 


\section{References}

Segelström, F. (2009). Communicating through visualizations: Service designers on visualizing user research. Paper presented at the DeThinking Design, ReThinking Services-First Nordic Conference on Service Design and Service Innovation.

Segelström, F., \& Holmlid, S. (2015). Ethnography by design: On goals and mediating artefacts. Arts and Humanities in Higher Education, 14(2), 134149 .

Seligman, M., E. P., \& Csikszentmihalyi, M. (2014). Positive Psychology: An Introduction. In Flow and the Foundations of Positive Psychology: The Collected Works of Mihaly Csikszentmihalyi (pp. 279-298). Dordrecht: Springer Netherlands.

Senbeto, D. L., \& Hon, A. H. Y. (2020). Market turbulence and service innovation in hospitality: examining the underlying mechanisms of employee and organizational resilience. The Service Industries Journal, 121.

Sergio, B., Robert, L., Javier, R., Marialuisa, S., \& James, S. (2016). Systems, networks, and ecosystems in service research. Journal of Service Management, 27(4), 652-674.

Sharma, V. C., Haran, A., Rakamaric, Z., \& Gopalakrishnan, G. (2013, 2-4 Dec. 2013). Towards Formal Approaches to System Resilience. Paper presented at the 2013 IEEE 19th Pacific Rim International Symposium on Dependable Computing.

Shneikat, B., \& Ryan, C. (2017). Syrian Refugees and their re-entry to 'normality': the role of service industries. The Service Industries Journal, 38(3-4), 201-227.

Shostack, G. L. (1977). Breaking Free from Product Marketing. Journal of Marketing, 41(2), 73-80.

Shostack, G. L. (1982). How to design a service. European Journal of Marketing, 16(1), 49-63.

Shostack, G. L. (1984). Designing services that deliver. Harvard Business Review, 62(1), 133-139.

Simon, H. (1969). The Sciences of the Artificial (First ed.): MIT Press, Cambridge, MA. 
Skovdal, M., \& Andreouli, E. (2011). Using Identity and Recognition as a Framework to Understand and Promote the Resilience of Caregiving Children in Western Kenya. Journal of Social Policy, 40(3), 613-630.

Snowden, D., \& Begovic, M. (2020). COVID-19 \& Leadership. Retrieved from https:// cognitive-edge.com/blog/covid-19-leadership/

Spohrer, J., Maglio, P., Bailey, J., \& Gruhl, D. (2007). Steps toward a science of service systems. Computer, 40(1), 71-77.

Spohrer, J., Piciocchi, P., \& Bassano, C. (2012). Three Frameworks for Service Research: Exploring Multilevel Governance in Nested, Networked Systems. Service Science, 4(2), 147-160.

Spohrer, J., Vargo, S., Caswell, N., \& Maglio, P. (2008). The service system is the basic abstraction of service science. Paper presented at the Proceedings of the 41st Annual Hawaii International Conference on System Sciences.

Steen, M., Manschot, M., \& De Koning, N. (2011). Benefits of co-design in service design projects. International Journal of Design, 5(2), 53-60.

Stickdorn, M., Schneider, J., Andrews, K., \& Lawrence, A. (2011). This is service design thinking: Basics, tools, cases: Wiley Hoboken, NJ.

Taysom, E., \& Crilly, N. (2017). Resilience in Sociotechnical Systems: The Perspectives of Multiple Stakeholders. She Ji: The Journal of Design, Economics, and Innovation, 3(3), 165-182.

Trischler, J., Pervan, S. J., Kelly, S. J., \& Scott, D. R. (2018). The Value of Codesign:The Effect of Customer Involvement in Service Design Teams. Journal of Service Research, 21(1), 75-100.

van der Bijl-Brouwer, M. (2017). Designing for Social Infrastructures in Complex Service Systems: A Human-Centered and Social Systems Perspective on Service Design. She Ji: The Journal of Design, Economics, and Innovation, 3(3), 183-197.

Van Riel, A., C. R., Zhang, J., J., McGinnis, L., Phillip, Nejad, M., G., Bujisic, M., \& Phillips, P., A. (2019). A framework for sustainable service system configuration. Journal of Service Management, 30(3), 349368. 


\section{References}

Van Vaerenbergh, Y., \& Orsingher, C. (2016). Service Recovery: An Integrative Framework and Research Agenda. The Academy of Management Perspectives, 30(3), 328-346.

Varca, P., E. (2004). Service skills for service workers: emotional intelligence and beyond. Managing Service Quality: An International Journal, 14(6), 457-467.

Vargo, S., \& Lusch, R. (2004a). Evolving to a New Dominant Logic for Marketing. Journal of Marketing, 68(1), 1-17.

Vargo, S., \& Lusch, R. (2004b). The Four Service Marketing Myths: Remnants of a Goods-Based, Manufacturing Model. Journal of Service Research, 6(4), 324-335.

Vargo, S., \& Lusch, R. (2008). Service-dominant logic: continuing the evolutions. Journal of the Academy of Marketing Science, 36(1), 1-10.

Vargo, S. L., \& Akaka, M. A. (2012). Value Cocreation and Service Systems (Re)Formation: A Service Ecosystems View. Service Science, 4(3), 207217.

Vargo, S. L., Koskela-Huotari, K., \& Vink, J. (2020). Service-Dominant Logic: Foundations and Applications. In E. Bridges \& K. Fowler (Eds.), The Routledge Handbook of Service Research Insights and Ideas (pp. 3-23): Routledge.

Vargo, S. L., \& Lusch, R. F. (2011). It's all B2B... and beyond: Toward a systems perspective of the market. Industrial Marketing Management, 40(2), 181-187.

Vargo, S. L., \& Lusch, R. F. (2016). Institutions and axioms: an extension and update of service-dominant logic. Journal of the Academy of Marketing Science, 44(1), 5-23.

Vargo, S. L., Lusch, R. F., Akaka, M. A., \& He, Y. (2010). The servicedominant logic of marketing: a review and assessment. Review of Marketing Research, 6(2), 125-167.

Vink, J. (2019). In/ visible - Conceptualizing Service Ecosystem Design. (Doctoral thesis, comprehensive summary). Karlstads universitet, Karlstad. Retrieved from http://urn.kb.se/resolve?urn=urn:nbn:se:kau:diva71967 DiVA database. (2019:17) 
Vink, J., Edvardsson, B., Wetter-Edman, K., \& Tronvoll, B. (2018). Reshaping mental models - enabling innovation through service design. Journal of Service Management.

Vink, J., Joly, M. P., Wetter-Edman, K., Tronvoll, B., \& Edvardsson, B. (2019). Changing the rules of the game in healthcare through service design. In Service Design and Service Thinking in Healthcare and Hospital Management (pp. 19-37): Springer.

Walker, B., Holling, C. S., Carpenter, S. R., \& Kinzig, A. (2004). Resilience, Adaptability and Transformability in Social-ecological Systems. Ecology and Society, 9(2).

Walker, B., Salt, D., \& Reid, W. (2006). Resilience Thinking : Sustaining Ecosystems and People in a Changing World. Washington, UNITED STATES: Island Press.

Wetter-Edman, K. (2009). Exploring overlaps and differences in service-dominant logic and design thinking. Paper presented at the 1st Nordic Conference on Service Design and Service Innovation, Oslo.

Wetter-Edman, K. (2011). Service Design-a conceptualization of an emerging practice.

Wetter-Edman, K. (2014). Design for Service: A framework for articulating designers' contribution as interpreter of users' experience.

Wetter-Edman, K., \& Malmberg, L. (2016). Experience and expertise: key issues for developing innovation capabilities through service design. Paper presented at the Service Design Geographies. Proceedings of the ServDes. 2016 Conference.

Wetter-Edman, K., Sangiorgi, D., Edvardsson, B., Holmlid, S., Grönroos, C., \& Mattelmäki, T. (2014). Design for value co-creation: exploring synergies between design for service and service logic. Service Science, 6(2), 106-121.

Wetter-Edman, K., Vink, J., \& Blomkvist, J. (2017). Staging aesthetic disruption through design methods for service innovation. Design Studies, 55, 5-26. 


\section{References}

Yu, E., \& Sangiorgi, D. (2014). Service design as an approach to new service development: reflections and future studies. Paper presented at the Fourth Service Design and Innovation Conference.

Yu, E., \& Sangiorgi, D. (2018a). Exploring the transformative impacts of service design: The role of designer-client relationships in the service development process. Design Studies, 55, 79-111.

Yu, E., \& Sangiorgi, D. (2018b). Service Design as an Approach to Implement the Value Cocreation Perspective in New Service Development. Journal of Service Research, 21(1), 40-58.

Zeithaml, V., Parasuraman, A., \& Berry, L. (1985). Problems and Strategies in Services Marketing. Journal of Marketing, 49(2), 33-46.

Zomerdijk, L., \& Voss, C. (2010). Service design for experience-centric services. Journal of Service Research, 13(1), 67-82. 


\section{Appendix A}

Overview of distribution of work.

\begin{tabular}{|c|c|c|c|c|c|c|}
\hline Papers & Contributors & Planning & $\begin{array}{c}\text { Data } \\
\text { Collection }\end{array}$ & Analysis & Writing & $\begin{array}{c}\text { Critical } \\
\text { review }\end{array}$ \\
\hline \multirow[t]{2}{*}{ Paper I } & $\begin{array}{l}\text { Vanessa } \\
\text { Rodrigues }\end{array}$ & & & & & \\
\hline & Co-authors & & & & & \\
\hline \multirow[t]{2}{*}{$\begin{array}{l}\text { Paper } \\
\text { II }\end{array}$} & $\begin{array}{l}\text { Vanessa } \\
\text { Rodrigues }\end{array}$ & & & & & \\
\hline & Co-authors & & & & & \\
\hline \multirow[t]{2}{*}{$\begin{array}{l}\text { Paper } \\
\text { III }\end{array}$} & $\begin{array}{l}\text { Vanessa } \\
\text { Rodrigues }\end{array}$ & & & & & \\
\hline & Co-authors & & & & & \\
\hline \multirow[t]{2}{*}{$\begin{array}{l}\text { Paper } \\
\text { IV }\end{array}$} & $\begin{array}{l}\text { Vanessa } \\
\text { Rodrigues }\end{array}$ & & & 0 & & \\
\hline & Co-authors & & & & & \\
\hline \multirow[t]{2}{*}{$\begin{array}{l}\text { Paper } \\
\text { V }\end{array}$} & $\begin{array}{l}\text { Vanessa } \\
\text { Rodrigues }\end{array}$ & $\Omega$ & 8 & 0 & 0 & \\
\hline & Co-authors & & & & & \\
\hline
\end{tabular}





\section{Appendix B}

Interview Protocol (Paper III)

\section{Introduction}

Good day! I would like to thank you for agreeing to participate in this research.

In order to facilitate my note-taking, I would like to audio tape our conversations today. For your information, only researchers on the project will be privy to the recorded conversations. This will be used be used for academic research purposes only. Your name will not be mentioned and the information you share can be traced back to you.

In addition, we kindly ask you to sign a form of informed consent. Essentially, this document states that: (1) all information will be held confidential, and (2) your participation is voluntary and you may stop at any time if you feel uncomfortable. You will also receive a signed copy of the form for your own records. Please feel free to ask me any questions you might have in relation to this.

I have planned this interview to last no longer than 1.5 hours. During this time, I have several questions that I would like to cover. If time begins to run short, it may be necessary to interrupt you in order to complete this line of questioning.

Our research project focuses on how employees react and what they do when they are faced with something unusual i.e. situations that are different from their normal routines. This study does not aim to evaluate your actions or experiences. There is no right or wrong answer. Rather, I am trying to understand more about what people do when faced with unexpected circumstances, and hopefully learn about how their practices affect the service. By service we mean work done by someone for the benefit of another. This includes but is not limited to service for monetary gains. For example, taking a bus, visiting the dentist and eating at a restaurant can be considered as services.

I will start with a short introduction of myself and then ask you a few background questions. I am Vanessa Rodrigues from India and am currently pursuing a $\mathrm{PhD}$ in Design at Linköping University, Sweden. I did my Masters in International Business at Maastricht University, The Netherlands. My professional background is in hospitality, consulting and more recently, service design. 


\section{INTERVIEWEE BACKGROUND}

a. Please tell me something about yourself.

b. Can you state your current position and briefly describe what you do here?

i. Probe: According to you, what kind of services do you offer here?

ii. Probe: How are you involved in the planning and designing of services here?

iii. Probe: How did you get involved?

c. When did you start your professional career?

d. Could you elaborate on your previous job experience?

i. Probe: What roles/positions have you previously held?

ii. Probe: Which fields or sectors have you worked in?

iii. Probe: How involved were you in the planning and designing of services in these roles?

\section{THE UNUSUAL SITUATION}

Normally, while working we observe certain routines and go about things as usual without any particular issues. However, sometimes things happen out of the blue and we have to respond to the situation as it unfolds.

a. Can you think back to a time where you or one of your colleagues encountered any unexpected or unusual situation while providing a service? Have you experienced anything like this in your work life? Please describe the nature of this situation.

i. Probe: What specific circumstances led up to this situation?

ii. Probe: When did this incident occur?

b. How did you handle the situation?

i. Probe: What options were available to you?

ii. Probe: What resources did you have at your disposal?

iii. Probe: Why did you do what you did?

iv. Probe: Could you have done anything differently?

c. How did this affect the delivery of the service?

i. Probe: Do you recall, how being in this situation made you feel? 
ii. Probe: How did the customer/user react? How did they express their concerns or appreciation?

d. Is there anything your learned from this situation? If yes, what? What did you learn from this situation?

\section{NETWORK PERSPECTIVE}

Carrying out services usually involves multiple people in one way or another. I would now like us to reflect on the roles and relationships of those involved in the situation you mentioned. To facilitate this, I have with me some actor cards that you may use to represent them.

a. Can you describe who else was involved in the situation? Using the cards, could you map their interactions in relation to this situation.

i. Probe: Who were the most important people?

b. Why was this person important?

i. Probe: What was their role?

ii. Probe: What did this person do/contribute?

iii. Probe: What resources did they utilize/bring to the service?

iv. Probe: How different was this in comparison to what they would do under normal circumstances?

c. Who was responsible for taking action in this situation?

i. Probe: Were you solely responsible?

ii. Probe: Who else was involved?

d. Did any of the other people contribute to resolving the situation?

iii. Probe: why or why not?

iv. Probe: Is there something they could have done? Could they have done anything more?

v. Probe: How did your boss/immediate supervisor react to how the situation was handled?

\section{ORGANISATIONAL/INSTITUTIONAL PERSPECTIVE}

a. How did the organization react to your efforts?

i. Probe: Were there any new measures implemented as a result of this situation?

ii. Probe: Were there any missed opportunities?

b. How empowered by the organisation did you (or your colleague) feel in this situation?

c. What was the strategy at the organisation with respect to handling such situations?

i. Probe: Did it work - why or why not?

ii. Probe: What would you do differently?

iii. Probe: What recovery mechanisms were in place (if any)? 
Appendix B

d. What are some of the major challenges you/your department faced in attempting to implementing services?

i. Probe: How could these barriers have been overcome?

\section{CLOSING}

We are now nearing the end of this interview.

- Is there anything else you would like to add or highlight?

- Do you know of somebody else I can talk to about this?

- Is there anything you would like to ask me?

- Would you be willing to have a follow-up interview if required? If it's fine I will be in touch with you regarding the same.

My contact details are listed on the informed consent form. Please do not hesitate to get in touch should you require any information or have further questions.

Thank you for your time and participation! 


\section{Appendix C}

Overview of workshop activities across sessions in Safe \& Effective Discharge Project.

\begin{tabular}{|c|c|}
\hline Session & Session activity \\
\hline \multirow[t]{15}{*}{ WS 1} & Kick-off Presentation \\
\hline & Guideline Presentation \\
\hline & Warm-up activity \\
\hline & Presentation on Service Design \& Person-Centred Care \\
\hline & Marshmallow Tower exercise (Two Iterations) \\
\hline & Problem Formulation exercise \\
\hline & $\begin{array}{l}\text { Visioning exercise } \\
\text {-Write email from patients to yourself about how your work has affected them }\end{array}$ \\
\hline & $\begin{array}{l}\text { Formulate Goal } \\
\text {-Our transformation work should... }\end{array}$ \\
\hline & Inspiration Presentation \\
\hline & $\begin{array}{l}\text { Phone a friend } \\
\text {-What does safety mean to you? }\end{array}$ \\
\hline & Adjusting the vision \\
\hline & $\begin{array}{l}\text { Knowledge gaps } \\
\text {-What we know } \\
\text {-What we assume } \\
\text {-What we don't know }\end{array}$ \\
\hline & Methods for data collection \\
\hline & Make a research plan \\
\hline & Closing \\
\hline \multirow[t]{7}{*}{ WS 1.1} & Opening check-in \\
\hline & Analysis presentation \\
\hline & User journey mapping \\
\hline & Affinity mapping \\
\hline & Insight prioritising matrix \\
\hline & Idea generation introduction \\
\hline & Reflection \\
\hline \multirow[t]{4}{*}{ WS 2} & Group presentations \\
\hline & Actor Mapping exercise \\
\hline & Presentation of maps \\
\hline & Closing \\
\hline
\end{tabular}




\section{Appendix C}

\begin{tabular}{|c|c|}
\hline Session & Session activity \\
\hline \multirow[t]{10}{*}{ WS 3} & Opening \\
\hline & Empathy Map \\
\hline & Re-Vision exercise \\
\hline & $\begin{array}{l}\text { Data collection } \\
\text { - Interview } \\
\text { - Observation } \\
\text { - Diary }\end{array}$ \\
\hline & $\begin{array}{l}\text { Iceberg Culture Map exercise } \\
\text {-Varying patterns/institutions (mindsets, norms) }\end{array}$ \\
\hline & $\begin{array}{l}\text { Organisational Vision Formulation } \\
\text {-Based on outcome of Ice-Berg culture map }\end{array}$ \\
\hline & $\begin{array}{l}\text { Pre-Mortum Game } \\
\text { - Organisational vision } \\
\text { - How can this go wrong? } \\
\text { - What can we do to avoid it? } \\
\text { - Rank order: Least-Most serious } \\
\text { - Points 1-5 for how difficult to fix }\end{array}$ \\
\hline & Presentation \\
\hline & Team project plan \\
\hline & Closing \\
\hline \multirow[t]{8}{*}{ WS 3.1} & Opening check-in \\
\hline & Analysis presentation \\
\hline & User journey mapping \\
\hline & Insight formulation \\
\hline & Affinity mapping \\
\hline & Insight prioritising matrix \\
\hline & Idea generation introduction \\
\hline & Reflection \\
\hline \multirow[t]{7}{*}{ WS 3.2} & Opening \\
\hline & Three-brain exercise \\
\hline & Brainstorming/Brainwriting \\
\hline & Opposites exercise \\
\hline & Idea cards \\
\hline & Idea Prioritising matrix \\
\hline & Closing \\
\hline \multirow[t]{4}{*}{ WS 4} & Opening \\
\hline & Team presentations \\
\hline & Roleplaying with feedback jury \\
\hline & Closing \\
\hline
\end{tabular}


Appendix C

\begin{tabular}{|c|c|}
\hline Session & Session Activity \\
\hline \multirow[t]{11}{*}{ WS 5} & Opening \\
\hline & $\begin{array}{l}\text { Team Presentations (Internal) } \\
\text { - User Group } \\
\text { - Idea/Solutions } \\
\text { - 'Parked' (Reserve) Ideas } \\
\text { - Why this idea? (Motivation) }\end{array}$ \\
\hline & Guideline presentation \\
\hline & Presentation poster making \\
\hline & Personal Journey Mapping (of the project process) \\
\hline & $\begin{array}{l}\text { Two wishes } \\
-2 \text { things you would need to take the next step \& } \\
\text { a star exercise } \\
\text { - one thing you see as a strength going to the next phase }\end{array}$ \\
\hline & Public presentation of project work \\
\hline & Panel discussion \\
\hline & Systemic Self workshop \\
\hline & Collaboration over Culture Guest Presentation \\
\hline & Felicitation of team members \\
\hline
\end{tabular}





\section{Papers}

The papers associated with this thesis have been removed for copyright reasons. For more details about these see:

http://urn.kb.se/resolve?urn=urn:nbn:se:liu:diva-165087 

Department of Computer and Information Science

Linköpings universitet

\section{Dissertations}

\section{Linköping Studies in Science and Technology Linköping Studies in Arts and Science \\ Linköping Studies in Statistics \\ Linköping Studies in Information Science}

Linköping Studies in Science and Technology

No 14 Anders Haraldsson: A Program Manipulation System Based on Partial Evaluation, 1977, ISBN 917372-144-1.

No 17 Bengt Magnhagen: Probability Based Verification of Time Margins in Digital Designs, 1977, ISBN 91-7372157-3.

No 18 Mats Cedwall: Semantisk analys av processbeskrivningar i naturligt språk, 1977, ISBN 91- 7372168-9.

No 22 Jaak Urmi: A Machine Independent LISP Compiler and its Implications for Ideal Hardware, 1978, ISBN 91-7372-188-3.

No 33 Tore Risch: Compilation of Multiple File Queries in a Meta-Database System, 1978, ISBN 91- 7372-232-4.

No 51 Erland Jungert: Synthesizing Database Structures from a User Oriented Data Model, 1980, ISBN 917372-387-8.

No 54 Sture Hägglund: Contributions to the Development of Methods and Tools for Interactive Design of Applications Software, 1980, ISBN 91-7372-404-1.

No 55 Pär Emanuelson: Performance Enhancement in a Well-Structured Pattern Matcher through Partial Evaluation, 1980, ISBN 91-7372-403-3.

No 58 Bengt Johnsson, Bertil Andersson: The HumanComputer Interface in Commercial Systems, 1981, ISBN 91-7372-414-9.

No 69 H. Jan Komorowski: A Specification of an Abstract Prolog Machine and its Application to Partial Evaluation, 1981, ISBN 91-7372-479-3.

No 71 René Reboh: Knowledge Engineering Techniques and Tools for Expert Systems, 1981, ISBN 91-7372489-0.

No 77 Östen Oskarsson: Mechanisms of Modifiability in large Software Systems, 1982, ISBN 91- 7372-527-7.

No 94 Hans Lunell: Code Generator Writing Systems, 1983, ISBN 91-7372-652-4.

No 97 Andrzej Lingas: Advances in Minimum Weight Triangulation, 1983, ISBN 91-7372-660-5.

No 109 Peter Fritzson: Towards a Distributed Programming Environment based on Incremental Compilation, 1984, ISBN 91-7372-801-2.

No 111 Erik Tengvald: The Design of Expert Planning Systems. An Experimental Operations Planning System for Turning, 1984, ISBN 91-7372- 805-5.

No 155 Christos Levcopoulos: Heuristics for Minimum Decompositions of Polygons, 1987, ISBN 91-7870133-3.

No 165 James W. Goodwin: A Theory and System for NonMonotonic Reasoning, 1987, ISBN 91-7870-183-X.

No 170 Zebo Peng: A Formal Methodology for Automated Synthesis of VLSI Systems, 1987, ISBN 91-7870-225-9.

No 174 Johan Fagerström: A Paradigm and System for Design of Distributed Systems, 1988, ISBN 91-7870301-8.
No 192 Dimiter Driankov: Towards a Many Valued Logic of Quantified Belief, 1988, ISBN 91-7870-374-3.

No 213 Lin Padgham: Non-Monotonic Inheritance for an Object Oriented Knowledge Base, 1989, ISBN 917870-485-5.

No 214 Tony Larsson: A Formal Hardware Description and Verification Method, 1989, ISBN 91-7870-517-7.

No 221 Michael Reinfrank: Fundamentals and Logical Foundations of Truth Maintenance, 1989, ISBN 917870-546-0.

No 239 Jonas Löwgren: Knowledge-Based Design Support and Discourse Management in User Interface Management Systems, 1991, ISBN 91-7870-720-X.

No 244 Henrik Eriksson: Meta-Tool Support for Knowledge Acquisition, 1991, ISBN 91-7870-746-3.

No 252 Peter Eklund: An Epistemic Approach to Interactive Design in Multiple Inheritance Hierarchies, 1991, ISBN 91-7870-784-6.

No 258 Patrick Doherty: NML3 - A Non-Monotonic Formalism with Explicit Defaults, 1991, ISBN 917870-816-8.

No 260 Nahid Shahmehri: Generalized Algorithmic Debugging, 1991, ISBN 91-7870-828-1.

No 264 Nils Dahlbäck: Representation of DiscourseCognitive and Computational Aspects, 1992, ISBN 91-7870-850-8.

No 265 Ulf Nilsson: Abstract Interpretations and Abstract Machines: Contributions to a Methodology for the Implementation of Logic Programs, 1992, ISBN 917870-858-3.

No 270 Ralph Rönnquist: Theory and Practice of Tensebound Object References, 1992, ISBN 91-7870-873-7.

No 273 Björn Fjellborg: Pipeline Extraction for VLSI Data Path Synthesis, 1992, ISBN 91-7870-880-X.

No 276 Staffan Bonnier: A Formal Basis for Horn Clause Logic with External Polymorphic Functions, 1992, ISBN 91-7870-896-6.

No 277 Kristian Sandahl: Developing Knowledge Management Systems with an Active Expert Methodology, 1992, ISBN 91-7870-897-4.

No 281 Christer Bäckström: Computational Complexity of Reasoning about Plans, 1992, ISBN 91-7870-979-2.

No 292 Mats Wirén: Studies in Incremental Natural Language Analysis, 1992, ISBN 91-7871-027-8.

No 297 Mariam Kamkar: Interprocedural Dynamic Slicing with Applications to Debugging and Testing, 1993, ISBN 91-7871-065-0.

No 302 Tingting Zhang: A Study in Diagnosis Using Classification and Defaults, 1993, ISBN 91-7871-0782.

No 312 Arne Jönsson: Dialogue Management for Natural Language Interfaces - An Empirical Approach, 1993, ISBN 91-7871-110-X.

No 338 Simin Nadjm-Tehrani: Reactive Systems in Physical Environments: Compositional Modelling and Framework for Verification, 1994, ISBN 91-7871-237-8. 
Bengt Savén: Business Models for Decision Support and Learning. A Study of Discrete-Event Manufacturing Simulation at Asea/ABB 1968-1993, 1995, ISBN 91-7871-494-X.

No 375 Ulf Söderman: Conceptual Modelling of Mode Switching Physical Systems, 1995, ISBN 91-7871-5164.

No 383 Andreas Kågedal: Exploiting Groundness in Logic Programs, 1995, ISBN 91-7871-538-5.

No 396 George Fodor: Ontological Control, Description, Identification and Recovery from Problematic Control Situations, 1995, ISBN 91-7871-603-9.

No 413 Mikael Pettersson: Compiling Natural Semantics, 1995, ISBN 91-7871-641-1.

No 414 Xinli Gu: RT Level Testability Improvement by Testability Analysis and Transformations, 1996, ISBN 91-7871-654-3.

No 416 Hua Shu: Distributed Default Reasoning, 1996, ISBN 91-7871-665-9.

No 429 Jaime Villegas: Simulation Supported Industrial Training from an Organisational Learning Perspective - Development and Evaluation of the SSIT Method, 1996, ISBN 91-7871-700-0.

No 431 Peter Jonsson: Studies in Action Planning: Algorithms and Complexity, 1996, ISBN 91-7871-7043.

No 437 Johan Boye: Directional Types in Logic Programming, 1996, ISBN 91-7871-725-6.

No 439 Cecilia Sjöberg: Activities, Voices and Arenas: Participatory Design in Practice, 1996, ISBN 91-7871728-0.

No 448 Patrick Lambrix: Part-Whole Reasoning in Description Logics, 1996, ISBN 91-7871-820-1.

No 452 Kjell Orsborn: On Extensible and Object-Relational Database Technology for Finite Element Analysis Applications, 1996, ISBN 91-7871-827-9.

No 459 Olof Johansson: Development Environments for Complex Product Models, 1996, ISBN 91-7871-855-4.

No 461 Lena Strömbäck: User-Defined Constructions in Unification-Based Formalisms, 1997, ISBN 91-7871857-0.

No 462 Lars Degerstedt: Tabulation-based Logic Programming: A Multi-Level View of Query Answering, 1996, ISBN 91-7871-858-9.

No 475 Fredrik Nilsson: Strategi och ekonomisk styrning En studie av hur ekonomiska styrsystem utformas och används efter företagsförvärv, 1997, ISBN 91 7871-914-3.

No 480 Mikael Lindvall: An Empirical Study of Requirements-Driven Impact Analysis in Object-Oriented Software Evolution, 1997, ISBN 91-7871-927-5.

No 485 Göran Forslund: Opinion-Based Systems: The Cooperative Perspective on Knowledge-Based Decision Support, 1997, ISBN 91-7871-938-0.

No 494 Martin Sköld: Active Database Management Systems for Monitoring and Control, 1997, ISBN 91 7219-002-7.

No 495 Hans Olsén: Automatic Verification of Petri Nets in a CLP framework, 1997, ISBN 91-7219-011-6.

No 498 Thomas Drakengren: Algorithms and Complexity for Temporal and Spatial Formalisms, 1997, ISBN 91 7219-019-1.

No 502 Jakob Axelsson: Analysis and Synthesis of Heterogeneous Real-Time Systems, 1997, ISBN 91-7219-035-3.
No 503 Johan Ringström: Compiler Generation for DataParallel Programming Languages from Two-Level Semantics Specifications, 1997, ISBN 91-7219-045-0.

No 512 Anna Moberg: Närhet och distans - Studier av kommunikationsmönster i satellitkontor och flexibla kontor, 1997, ISBN 91-7219-119-8.

No 520 Mikael Ronström: Design and Modelling of a Parallel Data Server for Telecom Applications, 1998, ISBN 91-7219-169-4.

No 522 Niclas Ohlsson: Towards Effective Fault Prevention - An Empirical Study in Software Engineering, 1998, ISBN 91-7219-176-7.

No 526 Joachim Karlsson: A Systematic Approach for Prioritizing Software Requirements, 1998, ISBN 917219-184-8.

No 530 Henrik Nilsson: Declarative Debugging for Lazy Functional Languages, 1998, ISBN 91-7219-197-X.

No 555 Jonas Hallberg: Timing Issues in High-Level Synthesis, 1998, ISBN 91-7219-369-7.

No 561 Ling Lin: Management of 1-D Sequence Data - From Discrete to Continuous, 1999, ISBN 91-7219-402-2.

No 563 Eva L Ragnemalm: Student Modelling based on Collaborative Dialogue with a Learning Companion, 1999, ISBN 91-7219-412-X.

No 567 Jörgen Lindström: Does Distance matter? On geographical dispersion in organisations, 1999, ISBN $91-$ 7219-439-1.

No 582 Vanja Josifovski: Design, Implementation and Evaluation of a Distributed Mediator System for Data Integration, 1999, ISBN 91-7219-482-0.

No 589 Rita Kovordányi: Modeling and Simulating Inhibitory Mechanisms in Mental Image Reinterpretation - Towards Cooperative HumanComputer Creativity, 1999, ISBN 91-7219-506-1.

No 592 Mikael Ericsson: Supporting the Use of Design Knowledge - An Assessment of Commenting Agents, 1999, ISBN 91-7219-532-0.

No 593 Lars Karlsson: Actions, Interactions and Narratives, 1999, ISBN 91-7219-534-7.

No 594 C. G. Mikael Johansson: Social and Organizational Aspects of Requirements Engineering Methods - A practice-oriented approach, 1999, ISBN 91-7219-541$\mathrm{X}$

No 595 Jörgen Hansson: Value-Driven Multi-Class Overload Management in Real-Time Database Systems, 1999, ISBN 91-7219-542-8.

No 596 Niklas Hallberg: Incorporating User Values in the Design of Information Systems and Services in the Public Sector: A Methods Approach, 1999, ISBN 917219-543-6.

No 597 Vivian Vimarlund: An Economic Perspective on the Analysis of Impacts of Information Technology: From Case Studies in Health-Care towards General Models and Theories, 1999, ISBN 91-7219-544-4.

No 598 Johan Jenvald: Methods and Tools in ComputerSupported Taskforce Training, 1999, ISBN 91-7219547-9.

No 607 Magnus Merkel: Understanding and enhancing translation by parallel text processing, 1999, ISBN 91 7219-614-9.

No 611 Silvia Coradeschi: Anchoring symbols to sensory data, 1999, ISBN 91-7219-623-8.

No 613 Man Lin: Analysis and Synthesis of Reactive Systems: A Generic Layered Architecture Perspective, 1999, ISBN 91-7219-630-0. 
No 618 Jimmy Tjäder: Systemimplementering i praktiken En studie av logiker i fyra projekt, 1999, ISBN 91 7219-657-2.

No 627 Vadim Engelson: Tools for Design, Interactive Simulation, and Visualization of Object-Oriented Models in Scientific Computing, 2000, ISBN 91-7219709-9.

No 637 Esa Falkenroth: Database Technology for Control and Simulation, 2000, ISBN 91-7219-766-8.

No 639 Per-Arne Persson: Bringing Power and Knowledge Together: Information Systems Design for Autonomy and Control in Command Work, 2000, ISBN 91-7219796-X.

No 660 Erik Larsson: An Integrated System-Level Design for Testability Methodology, 2000, ISBN 91-7219-890-7.

No 688 Marcus Bjäreland: Model-based Execution Monitoring, 2001, ISBN 91-7373-016-5.

No 689 Joakim Gustafsson: Extending Temporal Action Logic, 2001, ISBN 91-7373-017-3.

No 720 Carl-Johan Petri: Organizational Information Provision - Managing Mandatory and Discretionary Use of Information Technology, 2001, ISBN 91-7373-1269.

No 724 Paul Scerri: Designing Agents for Systems with Adjustable Autonomy, 2001, ISBN 91-7373-207-9.

No 725 Tim Heyer: Semantic Inspection of Software Artifacts: From Theory to Practice, 2001, ISBN 917373-208-7.

No 726 Pär Carlshamre: A Usability Perspective on Requirements Engineering - From Methodology to Product Development, 2001, ISBN 91-7373-212-5.

No 732 Juha Takkinen: From Information Management to Task Management in Electronic Mail, 2002, ISBN 917373-258-3.

No 745 Johan Åberg: Live Help Systems: An Approach to Intelligent Help for Web Information Systems, 2002, ISBN 91-7373-311-3.

No 746 Rego Granlund: Monitoring Distributed Teamwork Training, 2002, ISBN 91-7373-312-1.

No 757 Henrik André-Jönsson: Indexing Strategies for Time Series Data, 2002, ISBN 917373-346-6.

No 747 Anneli Hagdahl: Development of IT-supported Interorganisational Collaboration - A Case Study in the Swedish Public Sector, 2002, ISBN 91-7373-314-8.

No 749 Sofie Pilemalm: Information Technology for NonProfit Organisations - Extended Participatory Design of an Information System for Trade Union Shop Stewards, 2002, ISBN 91-7373-318-0.

No 765 Stefan Holmlid: Adapting users: Towards a theory of use quality, 2002, ISBN 91-7373-397-0.

No 771 Magnus Morin: Multimedia Representations of Distributed Tactical Operations, 2002, ISBN 91-7373-4217.

No 772 Pawel Pietrzak: A Type-Based Framework for Locating Errors in Constraint Logic Programs, 2002, ISBN 91-7373-422-5.

No 758 Erik Berglund: Library Communication Among Programmers Worldwide, 2002, ISBN 91-7373-349-0.

No 774 Choong-ho Yi: Modelling Object-Oriented Dynamic Systems Using a Logic-Based Framework, 2002, ISBN 91-7373-424-1.

No 779 Mathias Broxvall: A Study in the Computational Complexity of Temporal Reasoning, 2002, ISBN 917373-440-3.
No 793 Asmus Pandikow: A Generic Principle for Enabling Interoperability of Structured and Object-Oriented Analysis and Design Tools, 2002, ISBN 91-7373-479-9.

No 785 Lars Hult: Publika Informationstjänster. En studie av den Internetbaserade encyklopedins bruksegenskaper, 2003, ISBN 91-7373-461-6.

No 800 Lars Taxén: A Framework for the Coordination of Complex Systems' Development, 2003, ISBN 917373-604-X.

No 808 Klas Gäre: Tre perspektiv på förväntningar och förändringar $i$ samband med införande av informationssystem, 2003, ISBN 91-7373-618-X.

No 821 Mikael Kindborg: Concurrent Comics programming of social agents by children, 2003, ISBN 91-7373-651-1.

No 823 Christina Ölvingson: On Development of Information Systems with GIS Functionality in Public Health Informatics: A Requirements Engineering Approach, 2003, ISBN 91-7373-656-2.

No 828 Tobias Ritzau: Memory Efficient Hard Real-Time Garbage Collection, 2003, ISBN 91-7373-666-X.

No 833 Paul Pop: Analysis and Synthesis of Communication-Intensive Heterogeneous Real-Time Systems, 2003, ISBN 91-7373-683-X.

No 852 Johan Moe: Observing the Dynamic Behaviour of Large Distributed Systems to Improve Development and Testing - An Empirical Study in Software Engineering, 2003, ISBN 91-7373-779-8.

No 867 Erik Herzog: An Approach to Systems Engineering Tool Data Representation and Exchange, 2004, ISBN 91-7373-929-4.

No 872 Aseel Berglund: Augmenting the Remote Control: Studies in Complex Information Navigation for Digital TV, 2004, ISBN 91-7373-940-5.

No 869 Jo Skåmedal: Telecommuting's Implications on Travel and Travel Patterns, 2004, ISBN 91-7373-935-9.

No 870 Linda Askenäs: The Roles of IT - Studies of Organising when Implementing and Using Enterprise Systems, 2004, ISBN 91-7373-936-7.

No 874 Annika Flycht-Eriksson: Design and Use of Ontologies in Information-Providing Dialogue Systems, 2004, ISBN 91-7373-947-2.

No 873 Peter Bunus: Debugging Techniques for EquationBased Languages, 2004, ISBN 91-7373-941-3.

No 876 Jonas Mellin: Resource-Predictable and Efficient Monitoring of Events, 2004, ISBN 91-7373-956-1.

No 883 Magnus Bång: Computing at the Speed of Paper: Ubiquitous Computing Environments for Healthcare Professionals, 2004, ISBN 91-7373-971-5.

No 882 Robert Eklund: Disfluency in Swedish humanhuman and human-machine travel booking dialogues, 2004, ISBN 91-7373-966-9.

No 887 Anders Lindström: English and other Foreign Linguistic Elements in Spoken Swedish. Studies of Productive Processes and their Modelling using Finite-State Tools, 2004, ISBN 91-7373-981-2.

No 889 Zhiping Wang: Capacity-Constrained Production-inventory systems - Modelling and Analysis in both a traditional and an e-business context, 2004, ISBN 9185295-08-6.

No 893 Pernilla Qvarfordt: Eyes on Multimodal Interaction, 2004, ISBN 91-85295-30-2.

No 910 Magnus Kald: In the Borderland between Strategy and Management Control - Theoretical Framework and Empirical Evidence, 2004, ISBN 91-85295-82-5. 
No 918 Jonas Lundberg: Shaping Electronic News: Genre Perspectives on Interaction Design, 2004, ISBN 9185297-14-3.

No 900 Mattias Arvola: Shades of use: The dynamics of interaction design for sociable use, 2004, ISBN 9185295-42-6.

No 920 Luis Alejandro Cortés: Verification and Scheduling Techniques for Real-Time Embedded Systems, 2004, ISBN 91-85297-21-6.

No 929 Diana Szentivanyi: Performance Studies of FaultTolerant Middleware, 2005, ISBN 91-85297-58-5.

No 933 Mikael Cäker: Management Accounting as Constructing and Opposing Customer Focus: Three Case Studies on Management Accounting and Customer Relations, 2005, ISBN 91-85297-64-X.

No 937 Jonas Kvarnström: TALplanner and Other Extensions to Temporal Action Logic, 2005, ISBN $91-$ 85297-75-5.

No 938 Bourhane Kadmiry: Fuzzy Gain-Scheduled Visual Servoing for Unmanned Helicopter, 2005, ISBN $91-$ 85297-76-3.

No 945 Gert Jervan: Hybrid Built-In Self-Test and Test Generation Techniques for Digital Systems, 2005, ISBN 91-85297-97-6.

No 946 Anders Arpteg: Intelligent Semi-Structured Information Extraction, 2005, ISBN 91-85297-98-4.

No 947 Ola Angelsmark: Constructing Algorithms for Constraint Satisfaction and Related Problems - Methods and Applications, 2005, ISBN 91-85297-99-2.

No 963 Calin Curescu: Utility-based Optimisation of Resource Allocation for Wireless Networks, 2005, ISBN 91-85457-07-8.

No 972 Björn Johansson: Joint Control in Dynamic Situations, 2005, ISBN 91-85457-31-0.

No 974 Dan Lawesson: An Approach to Diagnosability Analysis for Interacting Finite State Systems, 2005, ISBN 91-85457-39-6.

No 979 Claudiu Duma: Security and Trust Mechanisms for Groups in Distributed Services, 2005, ISBN 91-8545754-X.

No 983 Sorin Manolache: Analysis and Optimisation of Real-Time Systems with Stochastic Behaviour, 2005, ISBN 91-85457-60-4.

No 986 Yuxiao Zhao: Standards-Based Application Integration for Business-to-Business Communications, 2005, ISBN 91-85457-66-3

No 1004 Patrik Haslum: Admissible Heuristics for Automated Planning, 2006, ISBN 91-85497-28-2.

No 1005 Aleksandra Tešanovic: Developing Reusable and Reconfigurable Real-Time Software using Aspects and Components, 2006, ISBN 91-85497-29-0.

No 1008 David Dinka: Role, Identity and Work: Extending the design and development agenda, 2006, ISBN 9185497-42-8.

No 1009 Iakov Nakhimovski: Contributions to the Modeling and Simulation of Mechanical Systems with Detailed Contact Analysis, 2006, ISBN 91-85497-43-X.

No 1013 Wilhelm Dahllöf: Exact Algorithms for Exact Satisfiability Problems, 2006, ISBN 91-85523-97-6.

No 1016 Levon Saldamli: PDEModelica - A High-Level Language for Modeling with Partial Differential Equations, 2006, ISBN 91-85523-84-4.

No 1017 Daniel Karlsson: Verification of Component-based Embedded System Designs, 2006, ISBN 91-85523-79-8
No 1018 Ioan Chisalita: Communication and Networking Techniques for Traffic Safety Systems, 2006, ISBN 9185523-77-1.

No 1019 Tarja Susi: The Puzzle of Social Activity - The Significance of Tools in Cognition and Cooperation, 2006, ISBN 91-85523-71-2.

No 1021 Andrzej Bednarski: Integrated Optimal Code Generation for Digital Signal Processors, 2006, ISBN 9185523-69-0.

No 1022 Peter Aronsson: Automatic Parallelization of Equation-Based Simulation Programs, 2006, ISBN 9185523-68-2.

No 1030 Robert Nilsson: A Mutation-based Framework for Automated Testing of Timeliness, 2006, ISBN 9185523-35-6.

No 1034 Jon Edvardsson: Techniques for Automatic Generation of Tests from Programs and Specifications, 2006, ISBN 91-85523-31-3.

No 1035 Vaida Jakoniene: Integration of Biological Data, 2006, ISBN 91-85523-28-3.

No 1045 Genevieve Gorrell: Generalized Hebbian Algorithms for Dimensionality Reduction in Natural Language Processing, 2006, ISBN 91-85643-88-2.

No 1051 Yu-Hsing Huang: Having a New Pair of Glasses Applying Systemic Accident Models on Road Safety, 2006, ISBN 91-85643-64-5.

No 1054 Åsa Hedenskog: Perceive those things which cannot be seen - A Cognitive Systems Engineering perspective on requirements management, 2006, ISBN 91-85643-57-2.

No 1061 Cécile Åberg: An Evaluation Platform for Semantic Web Technology, 2007, ISBN 91-85643-31-9.

No 1073 Mats Grindal: Handling Combinatorial Explosion in Software Testing, 2007, ISBN 978-91-85715-74-9.

No 1075 Almut Herzog: Usable Security Policies for Runtime Environments, 2007, ISBN 978-91-85715-65-7.

No 1079 Magnus Wahlström: Algorithms, measures, and upper bounds for Satisfiability and related problems, 2007, ISBN 978-91-85715-55-8.

No 1083 Jesper Andersson: Dynamic Software Architectures, 2007, ISBN 978-91-85715-46-6.

No 1086 Ulf Johansson: Obtaining Accurate and Comprehensible Data Mining Models - An Evolutionary Approach, 2007, ISBN 978-91-85715-34-3.

No 1089 Traian Pop: Analysis and Optimisation of Distributed Embedded Systems with Heterogeneous Scheduling Policies, 2007, ISBN 978-91-85715-27-5.

No 1091 Gustav Nordh: Complexity Dichotomies for CSPrelated Problems, 2007, ISBN 978-91-85715-20-6.

No 1106 Per Ola Kristensson: Discrete and Continuous Shape Writing for Text Entry and Control, 2007, ISBN 97891-85831-77-7.

No 1110 He Tan: Aligning Biomedical Ontologies, 2007, ISBN 978-91-85831-56-2.

No 1112 Jessica Lindblom: Minding the body - Interacting socially through embodied action, 2007, ISBN 978-9185831-48-7.

No 1113 Pontus Wärnestål: Dialogue Behavior Management in Conversational Recommender Systems, 2007, ISBN 978-91-85831-47-0.

No 1120 Thomas Gustafsson: Management of Real-Time Data Consistency and Transient Overloads in Embedded Systems, 2007, ISBN 978-91-85831-33-3. 
No 1127 Alexandru Andrei: Energy Efficient and Predictable Design of Real-time Embedded Systems, 2007, ISBN 978-91-85831-06-7.

No 1139 Per Wikberg: Eliciting Knowledge from Experts in Modeling of Complex Systems: Managing Variation and Interactions, 2007, ISBN 978-91-85895-66-3.

No 1143 Mehdi Amirijoo: QoS Control of Real-Time Data Services under Uncertain Workload, 2007, ISBN 97891-85895-49-6.

No 1150 Sanny Syberfeldt: Optimistic Replication with Forward Conflict Resolution in Distributed Real-Time Databases, 2007, ISBN 978-91-85895-27-4.

No 1155 Beatrice Alenljung: Envisioning a Future Decision Support System for Requirements Engineering - A Holistic and Human-centred Perspective, 2008, ISBN 978-91-85895-11-3.

No 1156 Artur Wilk: Types for XML with Application to Xcerpt, 2008, ISBN 978-91-85895-08-3.

No 1183 Adrian Pop: Integrated Model-Driven Development Environments for Equation-Based Object-Oriented Languages, 2008, ISBN 978-91-7393-895-2.

No 1185 Jörgen Skågeby: Gifting Technologies Ethnographic Studies of End-users and Social Media Sharing, 2008, ISBN 978-91-7393-892-1.

No 1187 Imad-Eldin Ali Abugessaisa: Analytical tools and information-sharing methods supporting road safety organizations, 2008, ISBN 978-91-7393-887-7.

No 1204 H. Joe Steinhauer: A Representation Scheme for Description and Reconstruction of Object Configurations Based on Qualitative Relations, 2008, ISBN 978-91-7393-823-5.

No 1222 Anders Larsson: Test Optimization for Core-based System-on-Chip, 2008, ISBN 978-91-7393-768-9.

No 1238 Andreas Borg: Processes and Models for Capacity Requirements in Telecommunication Systems, 2009, ISBN 978-91-7393-700-9.

No 1240 Fredrik Heintz: DyKnow: A Stream-Based Knowledge Processing Middleware Framework, 2009, ISBN 978-91-7393-696-5.

No 1241 Birgitta Lindström: Testability of Dynamic RealTime Systems, 2009, ISBN 978-91-7393-695-8.

No 1244 Eva Blomqvist: Semi-automatic Ontology Construction based on Patterns, 2009, ISBN 978-91-7393-683-5.

No 1249 Rogier Woltjer: Functional Modeling of Constraint Management in Aviation Safety and Command and Control, 2009, ISBN 978-91-7393-659-0.

No 1260 Gianpaolo Conte: Vision-Based Localization and Guidance for Unmanned Aerial Vehicles, 2009, ISBN 978-91-7393-603-3.

No 1262 AnnMarie Ericsson: Enabling Tool Support for Formal Analysis of ECA Rules, 2009, ISBN 978-91-7393598-2.

No 1266 Jiri Trnka: Exploring Tactical Command and Control: A Role-Playing Simulation Approach, 2009, ISBN 978-91-7393-571-5.

No 1268 Bahlol Rahimi: Supporting Collaborative Work through ICT - How End-users Think of and Adopt Integrated Health Information Systems, 2009, ISBN 978-91-7393-550-0.

No 1274 Fredrik Kuivinen: Algorithms and Hardness Results for Some Valued CSPs, 2009, ISBN 978-91-7393-525-8.

No 1281 Gunnar Mathiason: Virtual Full Replication for Scalable Distributed Real-Time Databases, 2009, ISBN 978-91-7393-503-6.
No 1290 Viacheslav Izosimov: Scheduling and Optimization of Fault-Tolerant Distributed Embedded Systems, 2009, ISBN 978-91-7393-482-4

No 1294 Johan Thapper: Aspects of a Constraint Optimisation Problem, 2010, ISBN 978-91-7393-464-0.

No 1306 Susanna Nilsson: Augmentation in the Wild: User Centered Development and Evaluation of Augmented Reality Applications, 2010, ISBN 978-917393-416-9.

No 1313 Christer Thörn: On the Quality of Feature Models, 2010, ISBN 978-91-7393-394-0.

No 1321 Zhiyuan He: Temperature Aware and DefectProbability Driven Test Scheduling for System-onChip, 2010, ISBN 978-91-7393-378-0.

No 1333 David Broman: Meta-Languages and Semantics for Equation-Based Modeling and Simulation, 2010, ISBN 978-91-7393-335-3.

No 1337 Alexander Siemers: Contributions to Modelling and Visualisation of Multibody Systems Simulations with Detailed Contact Analysis, 2010, ISBN 978-91-7393317-9.

No 1354 Mikael Asplund: Disconnected Discoveries: Availability Studies in Partitioned Networks, 2010, ISBN 978-91-7393-278-3.

No 1359 Jana Rambusch: Mind Games Extended Understanding Gameplay as Situated Activity, 2010 ISBN 978-91-7393-252-3.

No 1373 Sonia Sangari: Head Movement Correlates to Focus Assignment in Swedish, 2011, ISBN 978-91-7393-1540 .

No 1374 Jan-Erik Källhammer: Using False Alarms when Developing Automotive Active Safety Systems, 2011, ISBN 978-91-7393-153-3.

No 1375 Mattias Eriksson: Integrated Code Generation, 2011, ISBN 978-91-7393-147-2.

No 1381 Ola Leifler: Affordances and Constraints of Intelligent Decision Support for Military Command and Control - Three Case Studies of Support Systems, 2011, ISBN 978-91-7393-133-5.

No 1386 Soheil Samii: Quality-Driven Synthesis and Optimization of Embedded Control Systems, 2011, ISBN 978-91-7393-102-1.

No 1419 Erik Kuiper: Geographic Routing in Intermittentlyconnected Mobile Ad Hoc Networks: Algorithms and Performance Models, 2012, ISBN 978-91-7519981-8.

No 1451 Sara Stymne: Text Harmonization Strategies for Phrase-Based Statistical Machine Translation, 2012, ISBN 978-91-7519-887-3.

No 1455 Alberto Montebelli: Modeling the Role of Energy Management in Embodied Cognition, 2012, ISBN 978-91-7519-882-8.

No 1465 Mohammad Saifullah: Biologically-Based Interactive Neural Network Models for Visual Attention and Object Recognition, 2012, ISBN 978-91-7519-838-5.

No 1490 Tomas Bengtsson: Testing and Logic Optimization Techniques for Systems on Chip, 2012, ISBN 978-917519-742-5.

No 1481 David Byers: Improving Software Security by Preventing Known Vulnerabilities, 2012, ISBN 97891-7519-784-5.

No 1496 Tommy Färnqvist: Exploiting Structure in CSPrelated Problems, 2013, ISBN 978-91-7519-711-1. 
No 1503 John Wilander: Contributions to Specification, Implementation, and Execution of Secure Software, 2013, ISBN 978-91-7519-681-7.

No 1506 Magnus Ingmarsson: Creating and Enabling the Useful Service Discovery Experience, 2013, ISBN 97891-7519-662-6.

No 1547 Wladimir Schamai: Model-Based Verification of Dynamic System Behavior against Requirements: Method, Language, and Tool, 2013, ISBN 978-917519-505-6.

No 1551 Henrik Svensson: Simulations, 2013, ISBN 978-917519-491-2.

No 1559 Sergiu Rafiliu: Stability of Adaptive Distributed Real-Time Systems with Dynamic Resource Management, 2013, ISBN 978-91-7519-471-4.

No 1581 Usman Dastgeer: Performance-aware Component Composition for GPU-based Systems, 2014, ISBN 978-91-7519-383-0.

No 1602 Cai Li: Reinforcement Learning of Locomotion based on Central Pattern Generators, 2014, ISBN 978-917519-313-7.

No 1652 Roland Samlaus: An Integrated Development Environment with Enhanced Domain-Specific Interactive Model Validation, 2015, ISBN 978-917519-090-7.

No 1663 Hannes Uppman: On Some Combinatorial Optimization Problems: Algorithms and Complexity, 2015, ISBN 978-91-7519-072-3.

No 1664 Martin Sjölund: Tools and Methods for Analysis, Debugging, and Performance Improvement of Equation-Based Models, 2015, ISBN 978-91-7519-071-6.

No 1666 Kristian Stavåker: Contributions to Simulation of Modelica Models on Data-Parallel Multi-Core Architectures, 2015, ISBN 978-91-7519-068-6.

No 1680 Adrian Lifa: Hardware/Software Codesign of Embedded Systems with Reconfigurable and Heterogeneous Platforms, 2015, ISBN 978-91-7519-0402.

No 1685 Bogdan Tanasa: Timing Analysis of Distributed Embedded Systems with Stochastic Workload and Reliability Constraints, 2015, ISBN 978-91-7519-022-8.

No 1691 Håkan Warnquist: Troubleshooting Trucks Automated Planning and Diagnosis, 2015, ISBN 97891-7685-993-3.

No 1702 Nima Aghaee: Thermal Issues in Testing of Advanced Systems on Chip, 2015, ISBN 978-91-7685949-0.

No 1715 Maria Vasilevskaya: Security in Embedded Systems: A Model-Based Approach with Risk Metrics, 2015, ISBN 978-91-7685-917-9.

No 1729 Ke Jiang: Security-Driven Design of Real-Time Embedded System, 2016, ISBN 978-91-7685-884-4.

No 1733 Victor Lagerkvist: Strong Partial Clones and the Complexity of Constraint Satisfaction Problems: Limitations and Applications, 2016, ISBN 978-91-7685856-1.

No 1734 Chandan Roy: An Informed System Development Approach to Tropical Cyclone Track and Intensity Forecasting, 2016, ISBN 978-91-7685-854-7.

No 1746 Amir Aminifar: Analysis, Design, and Optimization of Embedded Control Systems, 2016, ISBN 978-917685-826-4.

No 1747 Ekhiotz Vergara: Energy Modelling and Fairness for Efficient Mobile Communication, 2016, ISBN 978-917685-822-6.
No 1748 Dag Sonntag: Chain Graphs - Interpretations, Expressiveness and Learning Algorithms, 2016, ISBN 978-91-7685-818-9.

No 1768 Anna Vapen: Web Authentication using ThirdParties in Untrusted Environments, 2016, ISBN 97891-7685-753-3.

No 1778 Magnus Jandinger: On a Need to Know Basis: A Conceptual and Methodological Framework for Modelling and Analysis of Information Demand in an Enterprise Context, 2016, ISBN 978-91-7685-713-7.

No 1798 Rahul Hiran: Collaborative Network Security: Targeting Wide-area Routing and Edge-network Attacks, 2016, ISBN 978-91-7685-662-8.

No 1813 Nicolas Melot: Algorithms and Framework for Energy Efficient Parallel Stream Computing on Many-Core Architectures, 2016, ISBN 978-91-7685623-9.

No 1823 Amy Rankin: Making Sense of Adaptations: Resilience in High-Risk Work, 2017, ISBN 978-917685-596-6.

No 1831 Lisa Malmberg: Building Design Capability in the Public Sector: Expanding the Horizons of Development, 2017, ISBN 978-91-7685-585-0.

No 1851 Marcus Bendtsen: Gated Bayesian Networks, 2017, ISBN 978-91-7685-525-6.

No 1852 Zlatan Dragisic: Completion of Ontologies and Ontology Networks, 2017, ISBN 978-91-7685-522-5.

No 1854 Meysam Aghighi: Computational Complexity of some Optimization Problems in Planning, 2017, ISBN 978-91-7685-519-5.

No 1863 Simon Ståhlberg: Methods for Detecting Unsolvable Planning Instances using Variable Projection, 2017, ISBN 978-91-7685-498-3.

No 1879 Karl Hammar: Content Ontology Design Patterns: Qualities, Methods, and Tools, 2017, ISBN 978-917685-454-9.

No 1887 Ivan Ukhov: System-Level Analysis and Design under Uncertainty, 2017, ISBN 978-91-7685-426-6.

No 1891 Valentina Ivanova: Fostering User Involvement in Ontology Alignment and Alignment Evaluation, 2017, ISBN 978-91-7685-403-7.

No 1902 Vengatanathan Krishnamoorthi: Efficient HTTPbased Adaptive Streaming of Linear and Interactive Videos, 2018, ISBN 978-91-7685-371-9.

No 1903 Lu Li: Programming Abstractions and Optimization Techniques for GPU-based Heterogeneous Systems, 2018, ISBN 978-91-7685-370-2.

No 1913 Jonas Rybing: Studying Simulations with Distributed Cognition, 2018, ISBN 978-91-7685-348-1.

No 1936 Leif Jonsson: Machine Learning-Based Bug Handling in Large-Scale Software Development, 2018, ISBN 978-91-7685-306-1.

No 1964 Arian Maghazeh: System-Level Design of GPUBased Embedded Systems, 2018, ISBN 978-91-7685175-3.

No 1967 Mahder Gebremedhin: Automatic and Explicit Parallelization Approaches for Equation Based Mathematical Modeling and Simulation, 2019, ISBN 978-91-7685-163-0.

No 1984 Anders Andersson: Distributed Moving Base Driving Simulators - Technology, Performance, and Requirements, 2019, ISBN 978-91-7685-090-9.

No 1993 Ulf Kargén: Scalable Dynamic Analysis of Binary Code, 2019, ISBN 978-91-7685-049-7. 
No 2001 Tim Overkamp: How Service Ideas Are Implemented: Ways of Framing and Addressing Service Transformation, 2019, ISBN 978-91-7685-025-1.

No 2006 Daniel de Leng: Robust Stream Reasoning Under Uncertainty, 2019, ISBN 978-91-7685-013-8.

No 2048 Biman Roy: Applications of Partial Polymorphisms in (Fine-Grained) Complexity of Constraint Satisfaction Problems, 2020, ISBN 978-91-7929-898-2.

No 2051 Olov Andersson: Learning to Make Safe Real-Time Decisions Under Uncertainty for Autonomous Robots, 2020, ISBN 978-91-7929-889-0.

No 2065 Vanessa Rodrigues: Designing for Resilience: Navigating Change in Service Systems, 2020, ISBN 978-91-7929-867-8.

Linköping Studies in Arts and Sciences

No 504 Ing-Marie Jonsson: Social and Emotional Characteristics of Speech-based In-Vehicle Information Systems: Impact on Attitude and Driving Behaviour, 2009, ISBN 978-91-7393-478-7.

No 586 Fabian Segelström: Stakeholder Engagement for Service Design: How service designers identify and communicate insights, 2013, ISBN 978-91-7519-554-4.

No 618 Johan Blomkvist: Representing Future Situations of Service: Prototyping in Service Design, 2014, ISBN 978-91-7519-343-4.

No 620 Marcus Mast: Human-Robot Interaction for SemiAutonomous Assistive Robots, 2014, ISBN 978-917519-319-9.

No 677 Peter Berggren: Assessing Shared Strategic Understanding, 2016, ISBN 978-91-7685-786-1.

No 695 Mattias Forsblad: Distributed cognition in home environments: The prospective memory and cognitive practices of older adults, 2016, ISBN 97891-7685-686-4.

No 787 Sara Nygårdhs: Adaptive behaviour in traffic: An individual road user perspective, 2020, ISBN 978-917929-857-9.

\section{Linköping Studies in Statistics}

No 9 Davood Shahsavani: Computer Experiments Designed to Explore and Approximate Complex Deterministic Models, 2008, ISBN 978-91-7393-976-8.

No 10 Karl Wahlin: Roadmap for Trend Detection and Assessment of Data Quality, 2008, ISBN 978-91-7393792-4.

No 11 Oleg Sysoev: Monotonic regression for large multivariate datasets, 2010, ISBN 978-91-7393-412-1.

No 13 Agné Burauskaite-Harju: Characterizing Temporal Change and Inter-Site Correlations in Daily and Subdaily Precipitation Extremes, 2011, ISBN 978-91-7393110-6.

No 14 Måns Magnusson: Scalable and Efficient Probabilistic Topic Model Inference for Textual Data, 2018, ISBN 978-91-7685-288-0.

\section{Linköping Studies in Information Science}

No 1 Karin Axelsson: Metodisk systemstrukturering- att skapa samstämmighet mellan informationssystemarkitektur och verksamhet, 1998. ISBN 9172-19-296-8.

No 2 Stefan Cronholm: Metodverktyg och användbarhet en studie av datorstödd metodbaserad systemutveckling, 1998, ISBN 9172-19-299-2.
No 3 Anders Avdic: Användare och utvecklare - om anveckling med kalkylprogram, 1999. ISBN 91-7219606-8.

No 4 Owen Eriksson: Kommunikationskvalitet hos informationssystem och affärsprocesser, 2000, ISBN 917219-811-7.

No 5 Mikael Lind: Från system till process - kriterier för processbestämning vid verksamhetsanalys, 2001, ISBN 91-7373-067-X.

No 6 Ulf Melin: Koordination och informationssystem i företag och nätverk, 2002, ISBN 91-7373-278-8.

No 7 Pär J. Ågerfalk: Information Systems Actability - Understanding Information Technology as a Tool for Business Action and Communication, 2003, ISBN 917373-628-7.

No 8 Ulf Seigerroth: Att förstå och förändra systemutvecklingsverksamheter - en taxonomi för metautveckling, 2003, ISBN 91-7373-736-4.

No 9 Karin Hedström: Spår av datoriseringens värden Effekter av IT i äldreomsorg, 2004, ISBN 91-7373-9634.

No 10 Ewa Braf: Knowledge Demanded for Action Studies on Knowledge Mediation in Organisations, 2004, ISBN 91-85295-47-7.

No 11 Fredrik Karlsson: Method Configuration method and computerized tool support, 2005, ISBN 91-8529748-8.

No 12 Malin Nordström: Styrbar systemförvaltning - Att organisera systemförvaltningsverksamhet med hjälp av effektiva förvaltningsobjekt, 2005, ISBN 91-8529760-7.

No 13 Stefan Holgersson: Yrke: POLIS - Yrkeskunskap, motivation, IT-system och andra förutsättningar för polisarbete, 2005, ISBN 91-85299-43-X.

No 14 Benneth Christiansson, Marie-Therese Christiansson: Mötet mellan process och komponent - mot ett ramverk för en verksamhetsnära kravspecifikation vid anskaffning av komponentbaserade informationssystem, 2006, ISBN 91-85643$22-X$. 


\section{FACULTY OF SCIENCE AND ENGINEERING}

Linköping Studies in Science and Technology, Dissertations No. 2065, 2020 Department of Computer and Information Science

Linköping University

SE-581 83 Linköping, Sweden

www.liu.se
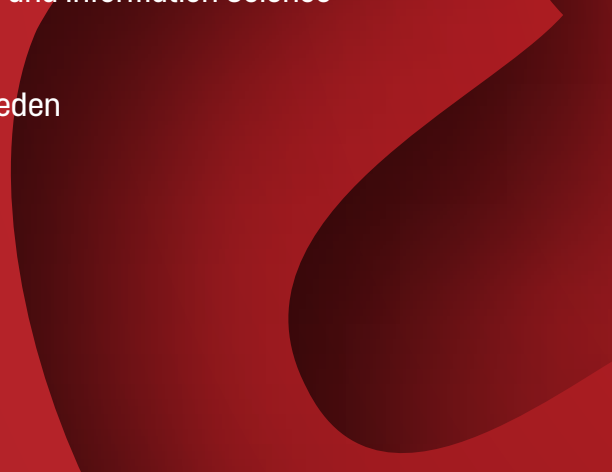